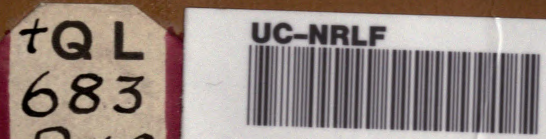 \\ R42 क D 54586}
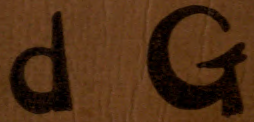

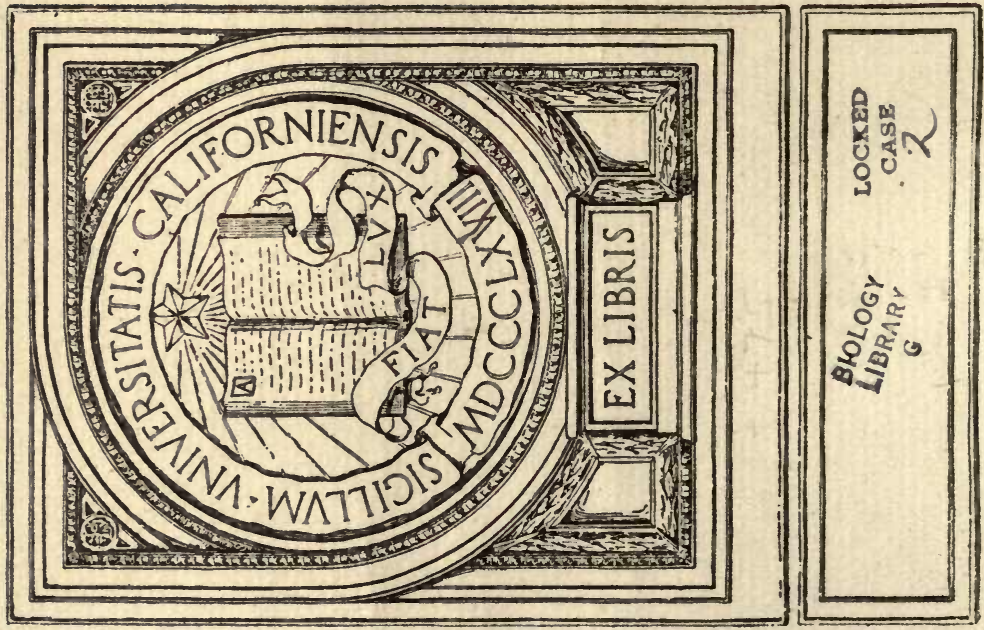



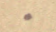




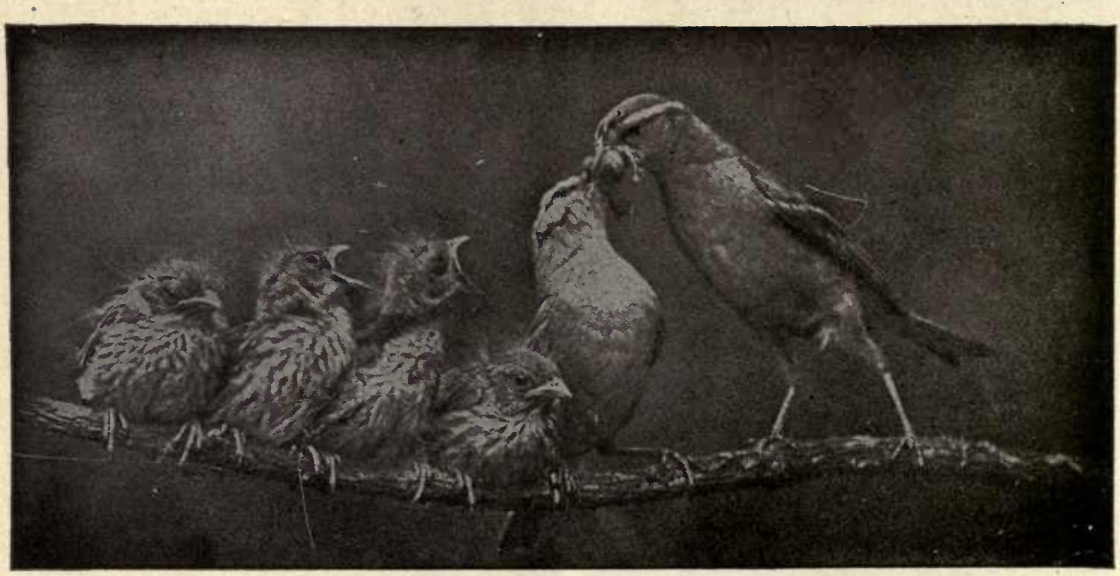

PREPARING BREAKFAST

(Two adult Chipping Sparrows breaking worm into pieces to feed young.) 


\title{
BIRD GUIDE
}

\section{LAND BIRDS EAST OF THE ROCKIES FROM PARROTS TO BLUEBIRDS}

\author{
BY \\ CHESTER A. REED \\ suthor of
}

North American Birds' Eggs, and, with Frarik Mi Chapman, of Color Key to North American Birds. Curator in Ornithology, Worcester Natural History Society.

GARDEN CITY NEW YORK

DOUBLEDAY, PAGE \& COMPANY 


\section{PREFACE.}

'The native birds are one of our nation's most valuable assets. Destroy them, and in a comparatively few years the insects will have multiplied to such an extent that trees will be denuded of their foliage, plants will cease to thrive and crops cannot be raised. This is not fancy but plain facts. Look at the little Chickadee on the side of this page. She was photographed while entering a bird box, with about twenty-five plant lice to feed her seven young; about two hundred times a day, either she or her mate, made trips with similar loads to feed the growing youngsters.

It has been found, by observation and dissection, that a Cuckoo consumes daily from 50 to 400 caterpillars or their equivalent, while a Chickadee will eat from 200 to 500 insects, or up to 4000 insect or worm eggs. 100 insects a day is a conservative estimate of the quantity consumed by each individual

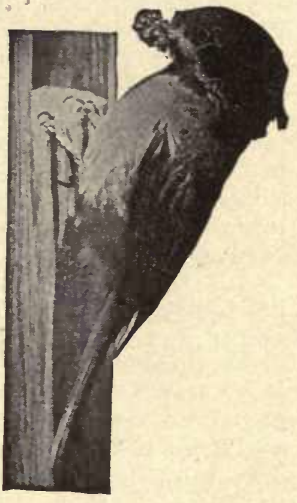

\section{4}


insecivorous bird. Ry carefilly estimating the birảs in several areas, I find that, in Massachusetts there are not less than five insect-eating birds per acre. Thus this state with its 8000 square miles' has a useful bird population of not less than $25,600,000$, which, for each day's fare, requires the enormous total of $2,560,000,000$ insects. That such figures can be expressed in terms better understood, it has been computed that about 120,000 average insects fill a bushel measure. This means that the daily consumption, of chiefly obnoxious insects, in Massachusetts is 21,000 bushels. This estimate is good for about five months in the year, May to September, inclusive; during the remainder of the year, the insects, eggs and larvae destroyed by our Winter, late Fall and early Spring migrants will be equivalent to nearly half this quantity.

It is the duty, and should be the pleasure, of every citizen to do all in his or her power to protect these valuable creatures, and to encourage them to remain about our homes. The author believes that the best means of protection is the disseminating of knowledge concerning them, and the creating of an interest in their habits and modes of life. With that object in view, this little book is prepared. May it serve its purpose and help those already interested in the subject, and may it be the medium for starting many others on the road to knowledge of our wild, feathered friends.

Worcester, Mass.,

CHESTER A. REED.

October 1st, 1905. 


\section{INTRODUCTION.}

It is an undisputed fact that a great many of our birds are becoming more scarce each year, while a few are, even now, on the verge of extinction. The decrease in numbers of a few species may be attributed chiefly to the elements, such as a long continued period of cold weather or ice storms in the winter, and rainy weather during the nesting season; howerer, in one way or another, and often unwittingly, man is chiefly responsible for the diminution in numbers. If I were to name the forces that work against the increase of bird life, in order of their importance, I should give them as:-Man; the elements; accidents; cats; other animals; birds of prey; and snakes. I do not take into consideration the death of birds from natural causes, such as old age and disease, for these should be counterbalanced by the natural increase.

There are parts that each one of us can play in lessening the unnatural dangers that lurk along a bird's path in life. Individually, our efforts may amount to but little, perhaps the saving of the lives of two or three, or more, birds during the year, but collectively, our efforts will soon be felt in the bird-world.

How Can We Protect the Birds? - Nearly all states have fairly good game laws, which, if they could be enforced. would properly protect our birds from man, but they cannot be; if our boys and girls are educated to realize the economic 
ralue of the birds, and are encouraged to study their habits, the desire to shoot them or to rob them of their eggs will be very materially lessened. It is a common practice for some farmers to burn their land over in the Spring, usually about nesting time. Three years ago, and as far back of that as I can remember, a small ravine or valley was teeming with bird life; it was the most favored spot that 1 know of, for the variety and numbers of its bird tenants. Last year, towards the end of May, this place was deliberately burned over by the owner. Twenty-seven nests that I know of, some with young, others with eggs, and still others in the process of construction, were destroyed, besides hundreds of others that I had never seen. This year the same thing was done earlier in the season, and not a bird nested here, and, late in Summer only a few clumps of ferns have found courage to appear above the blackened ground. Farmers also cut off a great many patches of underbrush that might just as well have been left, thus, for lack of suitable places for their homes, driving away some of their most valuable assistants. The cutting off of woods and forests is an important factor in the decrease of bird life, as well as upon the climate of the country:

Our winter birds have their hardships when snow covers the weed tops, and a coating of ice covers the trees, so that they can neither get seeds nor grubs. During the nesting season, we often have long-continued rains which sometimes cause an enormous loss of life to insect-eating birds and their young. In 1903, after a few weeks' steady rain and damp weather, not a Purple Martin could be found in Worcester County, nor, as far as I know, in New England; they were 
wholly unable to get food for either themselves or their young, and the majority of them left this region. The Martin houses, when cleaned out, were found to contain young, eggs and some adults that had starved rather than desert their family. The Martins did not return in 1904 or 1905.

Birds are subject to a great many accidents, chiefly by flying into objects at night. Telephone and telegraph wires maim or kill thousands, while lighthouses and steeples often cause the ground to be strewn with bodies during migrations. Other accidents are caused by storms, fatigue while crossing large bodies of water, nests falling from trees because of an insecure support, and ground nests being trod upon by man, horses and cattle.

In the vicinity of cities, towns, villages or farms, one of the most fertile sources of danger to bird life is from cats. Eren the most gentle household pet, if allowed its liberty out of doors, will get its full quota of birds during the year, while homeless cats, and many that are not, will average several hundred birds apiece during the season. After years of careful observation, Mr. E. H. Forbush, Mass., state ornithologist, has estimated that the average number of birds killed, per cat population, is about fifty. If a dog kills sheep or deer, he is shot and the owner has to pay damages; if a man is caught killing a bird, he pays a fine; but cats are allowed to roam about without restriction, leaving death and destruction in their wake. All homeless cats should be summarily dealt with, and all pets should be housed, at least from May until August, when the young birds are able to fly. 
Of wild animals, Red Squirrels are far the most destructive to young birds and eggs; Chipmunks and Grays are also destructive but not nearly as active or impudent as the Reds. Skunks, Foxes and Weasels are smaller factors in the decrease of bird life.

Birds of prey have but little to do with the question of bird protection for, with a few exceptions, they rarely feed upon other birds, and nearly all of them are of considerable economic value themselves. Jays, Crows and Grackles, by devouring the eggs and young of our smaller birds, are a far greater menace than are the birds of prey, but even these have their work and should be left in the place that Nature intended for them; they should, however, be taught to keep away from the neighborhood of houses.

How Can We Attract Birds About Our Homes?-Many birds prefer to live in the vicinity of houses, and they soon learn where they are welcome. Keep your premises as free as possible from cats, dogs. and especially English Sparrows, and other birds will come. Robins, Orioles, Kingbirds. Waxwings and a few others will nest in orchard trees. while in dead limbs or bird boxes will be found Bluebirds, Wrens, Swallows, Woodpeckers, Chickadees, etc.

A house for Purple Martins may contain many apartments; it should be erected in an open space, on a ten or twelve foot pole. Boxes for other birds sisuld have but one compartment, and should be about six by six by eight inches, with a hole at least one and one-half inches in diametor in one side; these can be fas- 
-ened in trees or on the sides or cornices of barns or sheds. It is needless to say that English Sparrows should not be allowed to use these boxes. By tying suet to limbs of trees in winter, and providing a small board upon which grain, crumbs, etc., may be sprinkled, large numbers of winter birds may be fed; of these, probably only the Chickadees will remain to nest, if they can find a suitable place.

How To Study Birds.-This refers, not to the scientific, but to the popular study of our birds, chiefly in the field. We can learn many very interesting things by watching our birds, especially during the nesting season, and the habits and peculiarities of many are still but imperfectly known. One thing to be impressed upon the student at the start is the need of very careful observation before deciding upon the identity of a bird with which you are not perfectly familiar. A bird's colors appear to differ greatly when viewed in different lights, while in looking up in the tree tops, it is often impossible to see any color at all without the aid of a good field glass. By the way, we would advise everyone to own a good pair of these, for, besides being almost indispensable for bird study, they are equally valuable for use at the seashore, in the mountains or at the theatre. [We have examined more than a hundred makes of field glasses to select the one best adapted to bird study, and at a moderate price. We found one that was far superior to any other at the same price, and was equal to most of those costing three times as much. It gives a rery clear image, magnifies about four diameters and has a very large field of view. It comes in a silk-lined leather case, with cord for 
suspending from the shoulder, ard is of a converient size for carryirg in the pocket. We have made arrangements so that we can sell these at a reasonable price (money refunded if they are not satisfactory after three days' trial).

We should also advise everyone to keep a note book, apart from the Birci Guide. At the end of the season you can write neatly with ink on the top of the pages of the Guide, the dates of the earliest arrivals and latest departures of the birds that you have recorded. If you see a bird that you do not recognize, make the following notes, as completely as possible:-Length (approximately); any bright colors or patches; shape of bill, whether most like that of a finch, warbler, etc.; has it a medium or superciliary line, eye ring, wing bars, or white in the tail; what are its notes or song; does it keep on or near the ground, or high up; are its actions quick or slow; upon what does it appear to be feeding; is it alone or with other birds, and what kind; where was it seen, in dry woods, swamp, pasture, etc.; date that it was seen. With this data you can identify any bird, but usually you will need only to glance over the pictures in the Bird Guide to find the name of the bird you have seen.

I should advise anyone by all means to make a complete local list of all the birds that are found in their neighborhood, but of far greater value than the simple recording of the different species seen on each walk, will be the making a special study of one or more birds, even though they be common ones. While, 
of course, noting any peculiarities of any bird that you may see, select some particular one or ones and find out all you can about it. The following most necessary points are cited to aid the student in making observations:-Date of arrival and whether in large flocks, pairs or singly; where found most abundantly; upon what do they feed at the different seasons; what are their songs and calls at different seasons; when and where do they make their nests; of what are they made and by which bird or both; how long does it take, and when is the first and last egg laid; how long does it take them to hatch, and do both birds or only one incubate them; upon what are the young fed at different ages; how long do they remain in the nest, and do they return after once leaving; how long before they are able to feed themselves, and do they remain with their parents until they migrate. These and other notes that will suggest themselves, will furnish interesting and valuable instruction during your leisure time. 


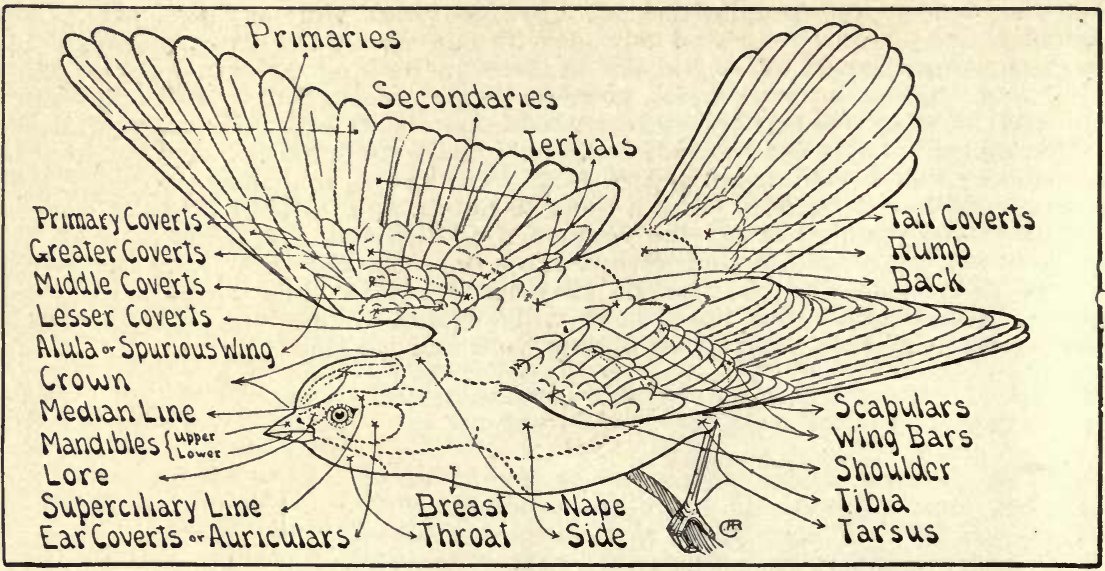

TOPOGRAPHY OI A BIRD. 


\section{B I R D U I D E}

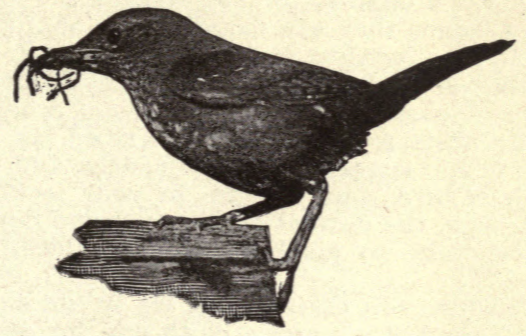

LAND BIRDS EAST OF THE ROCKIES 
The numbers and names used in this book are those adopted by the American Ornithologists' Union, and are known both in this country and abroad. The lengths given are averages; our small birds often vary considerably and may be found either slightly larger or smaller than those quoted.

On some of the pages a number of sub-species are mentioned. Sub-species often cause confusion, because they are usually very similar to the original ; they can best be identified by the locality in which they are found.

Of course the writing of birds' songs is an impossibility, but wherever I have thought it might prove of assistance, 1 have given a crude imitation of what it sounds like to me. The nests and eggs are described, as they often lead to the identity of a bird. We would suggest that you neatly, and with ink, make a cross against the name of each bird that you see in your locality, and also that you write at the top of the page, the date of the arrival and departure of each bird as you note it; these dates vary so much in different localities that we have not attempted to give them.

As many will not wish to soil their books, we would suggest that they have a leather covered copy for the library and a cloth one for pocket use. 


\section{CAROIINA PAROQUET,}

382. Conuropsis carolinensis. $121 / 2$ inches.

Adults have the fore part of the head orange, while young birds have the head entirely green, with only a trifle orange on the forehead.

With the exception of the Thick-billed Parrot which is very rarely found in southern Arizona, these are the only members of the Parrot family in the United States. They were once abundant throughout the southern states, but are now nearly extinct. They are found in heavily timbered regions, usually along the banks of streams, where they feed upon seeds and berries.

Note.-A sharp, rolling "kr-r-r-r-r." (Chapman.)

Nest.-Supposed to be in hollow trees, where they lay from three to five white eggs $(1.31 \times 1.06)$.

Range.-Formerly the southern states, but now confined to the interior of Florida and, possibly, Indian Territory.

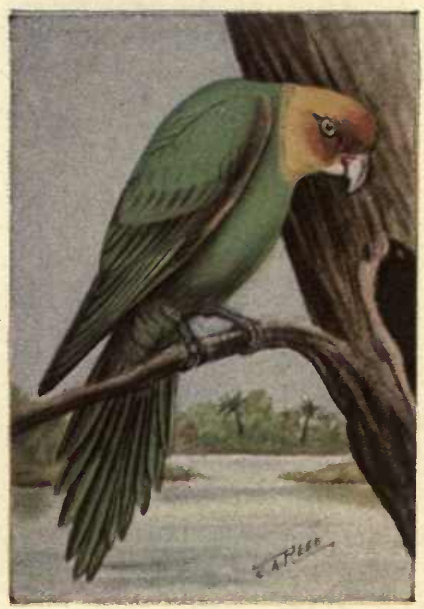




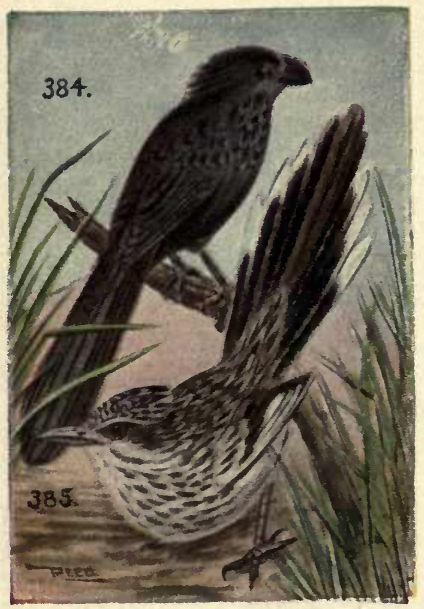

18

\section{GROOVE-BILLED ANI.}

384. Crotophaga sulcirostris. $141 / 2$ inches. Anis are fairly abundant in southern Texas along the Rio Grande. Like all the members of the family of Cuckoos, their nesting habits are very irregular; ofttimes a number of them will unite and form one large nest in a bush, in which all deposit their eggs. The eggs are bluish-green, covered with a white chalky deposit $(1.25 \times .95)$.

\section{ROAD-RUNNER.}

385. Geococcyx californianus. 23 inches.

In the southwestern portions of our country, from Texas and Kansas west to the Pacific, these curious birds are commonly found. They are locally known as "Ground Cuckoos," "Snake-killers," "Chaparral Cocks." They are very fond of lizards and small snakes, which form a large part of their fare. They are very fleet runners, but fly only indifferently well. Their four to ten white eggs are laid on frail nests of twigs, in bushes, 


\section{MANGROVE CUCROO.}

386. Coccyzus minor. 13 inches.

These buff-breasted Cuckoos are natives of Cuba and Central America, being found in southern Florida only during the summer. The habits of all the American Cuckoos are practically identical and their notes or songs can only be distinguished from one another by long familiarity.

\section{YELLOW-BILLED CUCKOO.}

387. Coccyzus americanus. 121/4 inches.

This species is the most abundant in the southern part of its range, while the Black-bill is the most common in the North. Notice that the lower mandible is yellowish, that the wings are largely rufous, and that the outer tail feathers are black, with broad white tips, these points readily distinguishing this species from the next. The eggs of this species are large and paler colored than the next $(1.20 \times .90)$. They breed from the Gulf to southern Canada and winter in Central America.

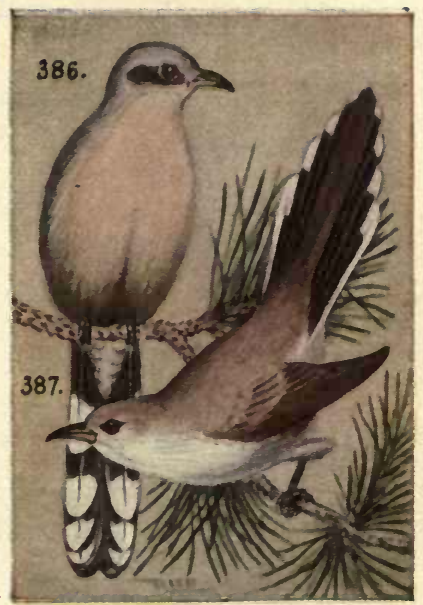

19 


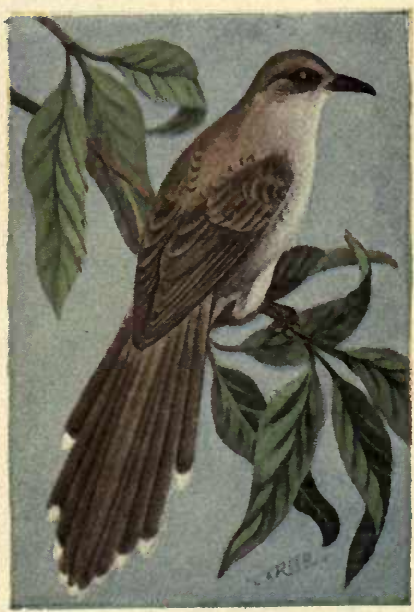

\section{BLACK-BILLED CUCKOO.}

388. Coccyzus erythropthalmus. $11 \%$ inches.

Cuckoos are of quiet and retiring habits, but on account of their mournful notes are often regarded with awe by the superstitious. They are one of our most valuable birds, for they consume quantities of the fuzzy Tent Caterpillars, that are so destructive.

Their short, rounded wings and long, broad tails give them a silent, gliding flight that often enables them to escape unnoticed.

Note.-A low guttural croak, "cow," “cow," etc., repeated a great many times and sometimes varied with "cow-uh," also repeated many times.

Nest.-Flat, shabby platforms of twigs placed at low elevations in thickets or on the lower branches of trees. The tour greenish-blue eggs are $1.15 \times .85$.

Range.-United States and southern Canada, east of the Rockies. Arrives in May and leaves in September for northern South America. 


\section{BELTED KINGFISHER.}

390. Ceryle alcyon. 13 inches.

The male has the breast band and sides blue-gray, like the back, while the female has chestnut-colored sides and breast band in addition to a gray band.

Kingfishers may be found about ponds, lakes, rivers, the sea-side or small creeks; anywhere that small fish may be obtained. Their food is entirely of fish that they catch by diving for, from their perches on dead branches, or by hovering over the water until the îsh are in proper positions and then plunging after them.

Note.-A very loud, harsh rattle, easily heard half a mile away on a clear, quiet day.

Nest.- At the end of a two or three-foot tunnel in a sand bank. The tunnel terminates in an enlarged chamber where the five to eight glossy white eggs ( $1.35 \mathrm{x}$ 1.05) are laid upon the sand.

Range.-Whole of North America north to the Arctic regions. Winters from southern United States southward.

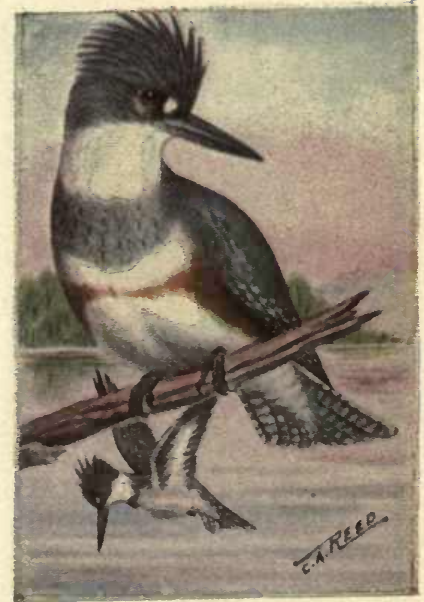




\section{TEXAS KINGFISHER.}

391. Ceryle americana septentrionalis. 8 inches.

The adult male of this species has a rufous breast band, while the female has only a greenish one.

The Texan Green Kingfisher is the smallest member of the family found within our borders. You will notice that all Kingfishers have the two outer toes on each foot joined together for about two-thirds of their length. This has been brought about through their habit of excavating in sand banks for nesting sites. It is quite probable that at some future distant period the three forward toes may be connected for their whole length, so as to give them a still more perfect shovel.

Note.-A rattling cry, more shrill than that of the Belted Kingfisher.

Nest.-'i'he four to six glossy white eggs are laid on the sand at the end of a horizontal burrow in a bank, the end being enlarged into a chamber sufficiently large to allow the parent bird to turn about.

Range.-Southwestern border of the United States, from southern Texas to Arizona. 


\section{IVORY-BILLED WOODPECKER.}

392. Campephilus principalis. 20 inches.

Male with a scarlet crest, female with a black one.

These are the largest and most rare of the Woodpeckers found within our borders. Their decline in numbers is due, to a certain extent, to the killing of them because of their size and beauty, but chiefly on account of cutting off of a great deal of the heavy timber where they nest. They are very powerful birds and often scale the bark off the greater portion of a tree in their search for insects and grubs, while they will bore into the heart of a living tree to make their home.

Note.-A shrill two-syllabled shriek or whistle.

Nest.- In holes of large trees in impenetrable swamps. On the chips at the bottom of the cavity, they lay from three to six glossy, pure white eggs (1.45 x 1.00).

Range.-Formerly the South Atlantic States and west to Texas and Indian Territory, but now confined to a few isolated portions of Florida and, possibly, Indian Territory.

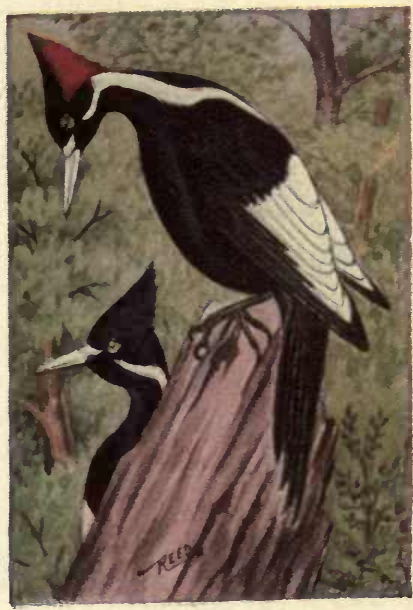




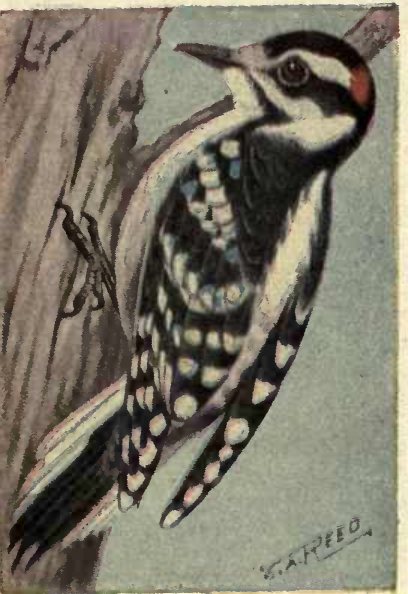

24

\section{HAIRY WOODPECKER.}

393. Dryobates villosus. 9 inches.

In summer these Woodpeckers are found in heavy woods, where they breed, but in winter they are often seen on trees about houses, even in the larger cities, hunting in all the crevices of the bark in the hope of locating the larva of some insect. They are usually more shy than the Downy, from which they can readily be distinguished by their much larger size.

Note.-A sharp whistled "peenk."

Nest.-In holes in trees in deep woods; three to six glossy white eggs $(.95 \times .70)$.

Range.-Eastern U. S. from Canada to North Carolina.

Sub-species.-393a. Northern Hairy Woodpecker (leucomelas), British America and Alaska; larger.393b. Southern Hairy Woodpecker (audubonii), South Atlantic and Gulf States; smaller. The difference between these birds is small and chiefly in size, although the southern bird often has fewer white marks on the wing coverts. Other sub-species are found west of the Roçkies. 
SOUTHERN DOWNY WOODPECKER.

394. Dryobates pubescens. 6 inches.

The male has a red nuchal patch while the female has none. Downies are one of the commonest of our Woodpeckers and are usually tame, allowing a very close approach before flying. They remain in orchards and open woods throughout the summer, and in winter often come to the windows in places where they are fed, as many people are in the habit of doing now. Their food, as does that of nearly all the Woodpeckers, consists entirely of insects, grubs and larvæ.

Note.-A sharp "peenk" or a rapid series of the same note, usually not as loud as that of the Hairy Woodpecker.

Nest.-In holes in trees in orchards or woods, the four to six white eggs being laid on the bare wood; size $.75 \times .60$.

Range.- South Atlantic and Gulf States.

Sub-species.-Northern Downy Woodpecker (medianus), North America east of the Rockies and north of the Carolinas. This variety is slightly larger than the southern; others are found west of the Rockies.

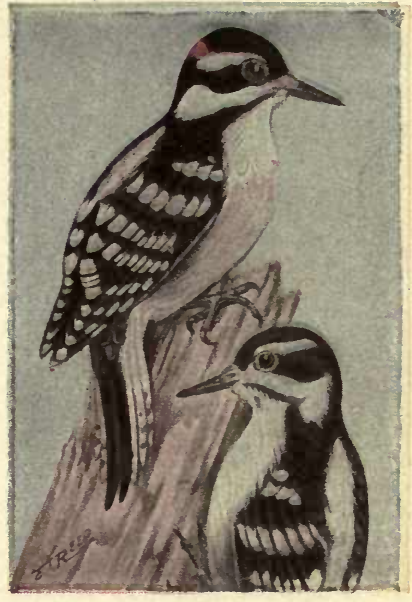




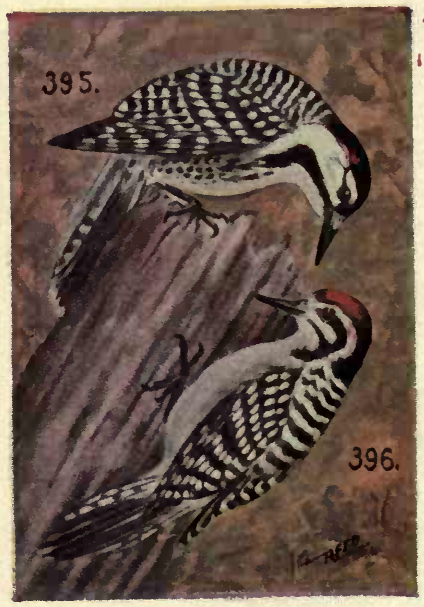

\section{RED-COCKADED WOODPECKER.}

395. Dryobates borealis. $81 / 4$ inches.

Male with a small patch of scarlet on both sides of the head; female without. The actions and habits are very similar to those of the Downy. The birds can readily be identified at a distance by the cross-barring of white on the back. Their notes are harsher than those of the Downy and have more of the nasal quality, like those of the nuthatches.

Range.-Söutheastern United States, west to Texas and north to Virginia.

\section{TEXAN WOODPECKER.}

396. Dryobates scalaris bairdi. $7 \frac{1}{4}$ inches.

On account of its numerous cross bars, this species is often known as the Ladder-backed Woodpecker. They are quite similar to the Nuttall Woodpecker, that is found on the Pacific Coast, but differ in having the underparts brownish-white instead of white, and the outer tail feathers heavily barred. They are found from Texas to southeastern California and north to Colorado. 


\section{ARCTIC THREE-TOED WOODPECKER.}

400. Picoides arcticus. 9.5 inches.

Back glossy black, without any white. Only three toes, two in front and one behind. This is the most common of the two species found within the United States. They breed from the northern edge of the Union north to the limit of trees.

\section{AMERICAN THREE-TOED WOODPECKER.}

401. Picoides americanus. $8 \frac{3}{4}$ inches.

Back barred with white; outer tail feathers barred with black; yellow crown patch on male mixed with white. Except on some of the higher mountain ranges these birds appear in the United States only during winter. They are very hardy and commence nesting before snow leaves.

Note.-A shrill, loud, nasal shriek, sometimes repeated.

Nest.-In holes of trees as is usual with Woodpeckers. The white eggs measure $.95 \times .70$.

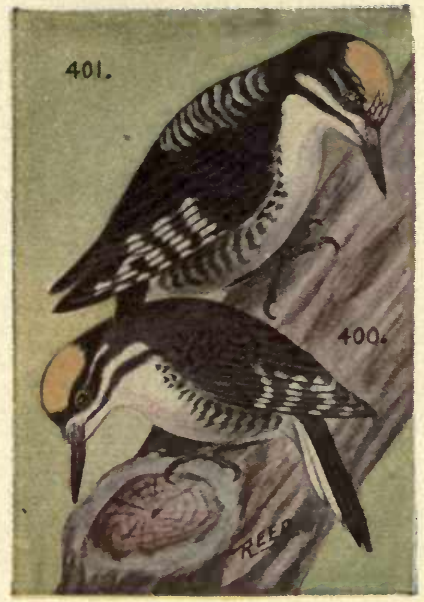

27 


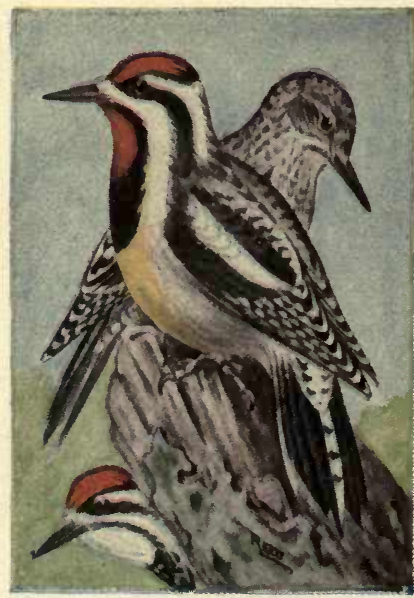

28

\section{YELLOW-BELLIED SAPSUCKER.}

402. Sphyrapicus varius. $81 / 2$ inches.

Male with a scarlet crown and throat; female with a scarlet crown and white throat; young with the head and neck mottled gray and white, with a few scarlet feathers.

This species has gained some ill-repute because of its supposed habit of boring through the bark of trees in order to get at the sap, and thus killing the trees. However, I very much doubt if they do any appreciable damage in this manner. I have watched a great many of them in the spring and fall and have clearly seen that they were feeding upon insects in the same way as the Downy.

iNote.-A loud whining "whee," and other harsh calls similar to the scream of a Blue Jay.

Nest.-In holes in trees, at heights from the ground varying from eight to fifty feet. Late in May they lay from four to seven white eggs $(.85 \times .60)$.

Range.-U. S. east of the Rockies, breeding from Virginia and Missouri to Hudson Bay, and wintering in southern U. S. 


\section{PILEATED WOODPECKER.}

405. Phloeotomus pileatus. 17 inches.

Male with a scarlet crown and crest, and a red moustache or mark extending back from the bill; female with scarlet crest but a blackish forehead and no moustache.

Next to the Ivory-bills, these are the largest of our Woodpeckers. Like that species it is very destructive to trees in its search for food. While engaged in this pursuit, they often drill large holes several inches into sound wood to reach the object of their search. Like all the Woodpeckers, they delight in playing tattoos on dry, resonant limbs with their bills.

Note.-A whistled "cuk," "cuk," "cuk," slowly repeated many times, also a "wick-up" repeated several times.

Nest.- In large cavities in trees, in which they lay four to six white eggs $(1.30 \times 1.00)$.

Range.-Southern United States. The Northern Pileated Woodpecker (abieticola) is locally found in temperate N. A.

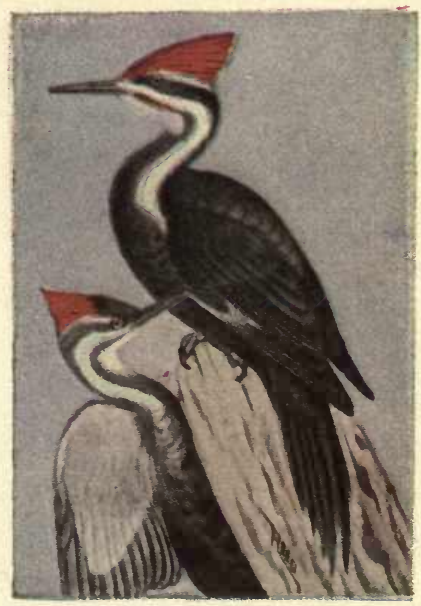

29 


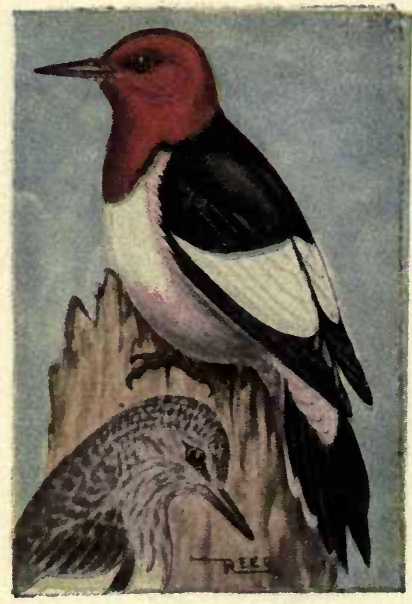

\section{RED-HEADED WOODPECKER.}

406. Melanerpes erythrocephalus. $93 / 4$ inches. Adults with entire head and breast red; young with a gray head and back, streaked with darker.

This very handsome species is common and very well known in the Middle and Central States. They are the ruffians of the family, very noisy and quarrelsome. One of their worst traits is the devouring of the eggs and young of other birds. To partially off set this, they also eat insects and grubs and a great deal of fruit.

Note.-A loud, whining "charr," "charr," besides numerous other calls and imitations.

Nest.-Holes in trees in woods, orchards or along roadsides and also in fence posts or telegraph poles. In May and June they lay four to six glossy white eggs $(1.00 \times .75)$.

Range.-United States east of the Rockies, breeding from the Gulf to New York and Minnesota. Winters in southern United States. 


\section{RED-BELIIED WOODPECKER.}

409. Centurus carolinus. $91 / 2$ inches.

Male with whole top of head and back of neck red; female with forehead and hind head red but crown gray. Both sexes have the center of the belly reddish, and have red eyes.

Like the Red-heads, these birds are noisy, but they have few of the bad qualities of the others. Besides the regular Woodpecker fare, they get a great many ants and beetles from the ground and fruit and acorns from the trees. They are said to also be fond of orange juice. In most of their range they are regarded as rather shy and retiring birds.

Note.-A sharp, resonant "cha," "cha," "cha," repeated.

Nest.-In holes bored usually in live trees and at any height from the ground. Their five or six eggs are glossy white $(1.00 \times .75)$.

Range.-United States east of the Plains, breeding from Florida and Texas to southern Pennsylvania and Minnesota. Winters along the Gulf coast; occasionally strays to Massachusetts.

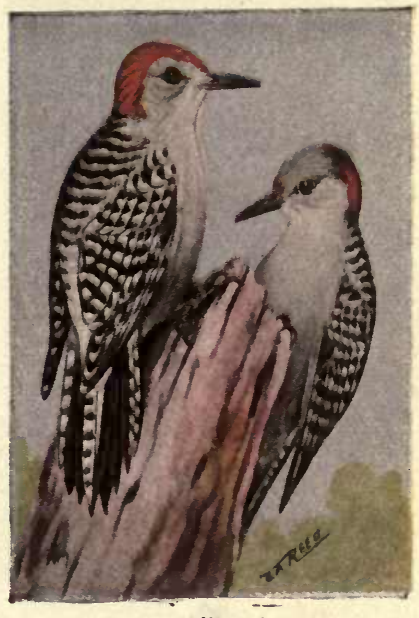

31 


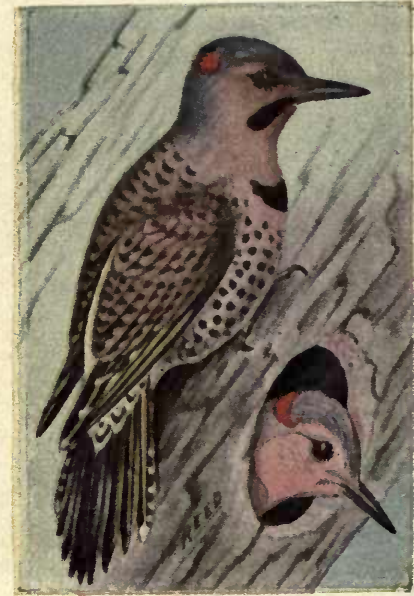

32.

\section{FLICKER.}

412. Colaptes auratus. 13 inches.

Male with a black moustache mark; female without, although young females in the first plumage show some black.

These birds are very often known as "Golden-winged Woodpeckers," "High-holes" and about a hundred other names in different localities. Flickers are found commonly in woods, orchards or trees by the roadside; on pleasant days their rapidly uttered, rolling whistle may be heard at all hours of the day.

Note.-A rapidly repeated whistle, "cuk," "cuk," "cuk"; an emphatic "quit-u," "quit-u," and several others of a similar nature.

Nest.-A cavity in a tree, at any distance from the ground. The white eggs usually vary in number from five to ten, but they have been known to lay as many as seventy-one, where an egg was taken from the nest each day.

Range. - South Atlantic States. The Northern Flicker (luteus) is found in North Amcrica east of the Rocky Mountains. 


\section{RED-SHAFTED FLICKER.}

413. Colaptes cafer collaris. 13 inches.

Crown brown and throat gray, these colors being just reversed from those of the common Flicker.

The male is distinguished by a red moustache mark, which the female lacks. The typical male Red-shafted Flicker lacks the red crescent on the back of the head, but it is often present on individuals, as there are numerous hybrids between this species and the preceding. Flickers are more terrestrial in their habits than are any others of the family; their food consists largely of ants which they get from the ground.

Note.-Same as those of the last; both species often utter a purring whistle when they are startled from the ground.

Nest.-The nesting habits are identical with those of the last and the eggs cannot be distinguished.

Range.-From the eastern slope of the Rocky Mountains to the Pacific.

8

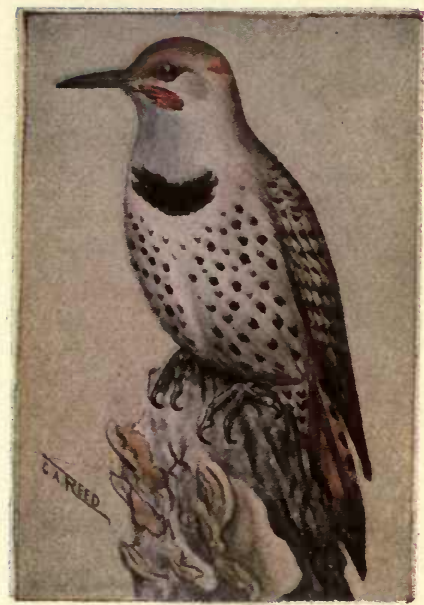




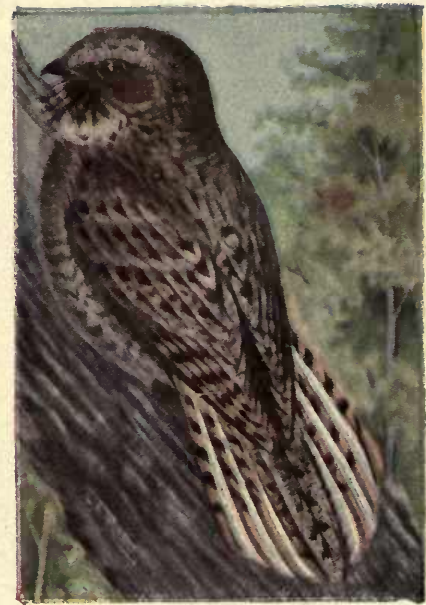

34

\section{CHUCK-WILL'S-WIDOW.}

416. Antrostomus carolinensis. 12 inches.

Male with the end half of the outer tail feathers white, and the edge of the outer vanes rusty; female with no white ends to the feathers. Birds of this family have small bills, but extremely large mouths adapted to catching night-flying moths and other insects. They remain sleeping during the day, either perched lengthwise on a limb or concealed beside a stump or rock on the ground, their colors harmonizing with the surroundings in either case. They fly, of their own accord, only at dusk or in the early morning. This species, which is much the largest of our Goatsuckers, is known to, at times, devour small birds, as such have been found in their stomachs.

Note.-A loudly whistled and repeated "chuck-will'swidow."

Nest.-None, the two eggs being laid on the ground or dead leaves in underbrush. Eggs white, blotched with gray and lavender $(1.40 \times 1.00)$.

Range.-South Atlantic and Gulf States, breeding north to Virginia and Missouri, west to Texas. 


\section{WHIP-POOR-WILL.}

417. Antrostomus vociferus. $93 / 4$ inches.

Male with broad white tips to outer tail feathers; female with narrow buffy tips. These birds are often confounded with the Nighthawk, but are very easily distinguished by the long bristles from base of bill, the black chin, the chestnut and black barred wing feathers and the rounded tail. Whip-poor-wills are more nocturnal than Nighthawks and on moonlight nights continue the whistled repetition of their name throughout the night. They capture and devour a great many of the large-bodied moths that are found in the woods, but are never seen flying over eities like Nighthawks.

Note.-An emphatically whistled repetition of "whippoor-will," "whip-poor-will."”

Nest.-In June they lay two grayish or creamy white eggs $(1.15 \times .85)$, mottled with pale brown, gray and lilac. These are deposited on the ground in woods.

Range.-East of the Plains, breeding from the Gulf to Manitoba and New Brunswick. Winters south of the United States.

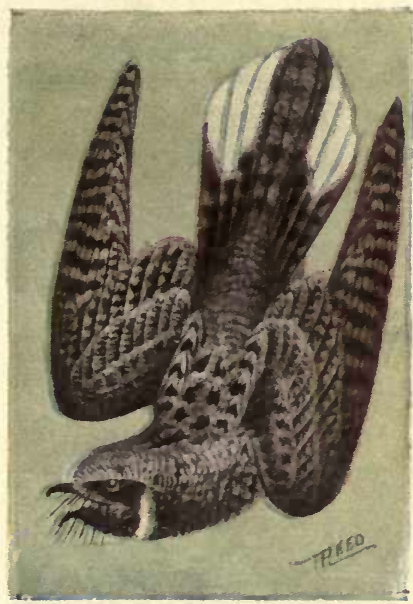

35 


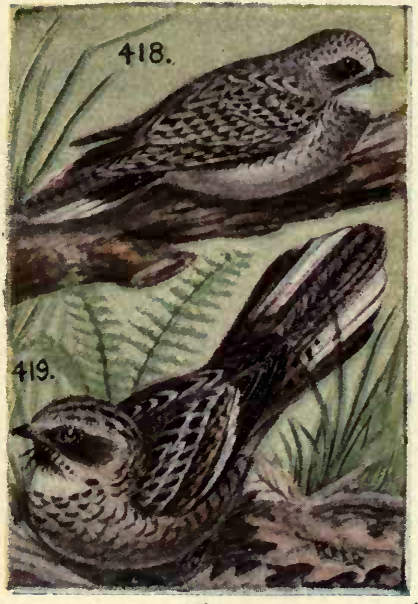

\section{POOR-WILL.}

418. Phalanoptilus nuttalli. $71 / 2$ inches.

The female of this beautiful little Night-jar differs from the male only in having narrow buffy tips to the outer tail feathers instead of broad white ones. Like all the members of this family these birds are dusk fliers, remaining at rest on the ground in daylight. Their frosted gray plumage harmonizes so perfectly with their surroundings that it is almost impossible to see them. Their eggs are nearly immaculate, but usually show traces of the lavender blotches that mark others of the family. Their call is a mournful "poor-will-ee." They are found from the Plains to the Pacific, but are not common east of the Rockies.

\section{MERRILL PARAQUE.}

419. Nyctidromus albicollis merrilli. 13 inches.

As usual with birds of this family, sexual difference in the plumage occurs chiefly on the tips of the outer tail feathers. These birds are common in the Lower Rio Grande Valley in Texas. Their eggs differ from any of the preceding in having a salmon-colored ground. 


\section{NIGHTHAWR.}

420. Chordeiles virginianus. 10 inches.

Male with white throat and white band across tail; female with rusty throat and no white on tail. Notice that the Nighthawk has a forked tail and white band across the wings, thus being readily distinguished at a distance from the Whip-poor-will.

Note.-A loud nasal "peent."

Nest.- None, the two mottled gray and white eggs being laid on bare rocks in pastures, on the ground or under brush, or on gravel roofs in cities; size $1.20 \times .85$. Range.-United States east of the Plains, breeding from Florida to Labrador; winters south of United States. Three sub-species occur:-420a. Western Nighthawk (henryi), west of the Plains; $420 \mathrm{~b}$. Florida Nighthawk (chapmani); 420c. Sennett Nighthawk (sennetti), a pale race found on the Plains north to Saskatchewan.

\section{TEXAN NIGHTHAWK}

421. Chordeiles acutipennis texensis.

This species is found in southern Texas and New Mexico. It differs from the last in having the primaries spotted with rusty, like those of the whip-poor-will.

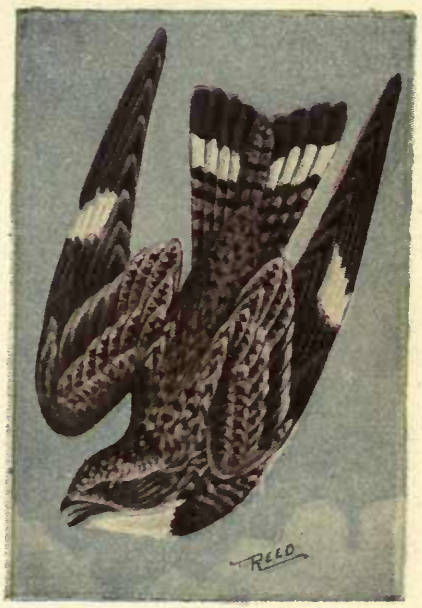




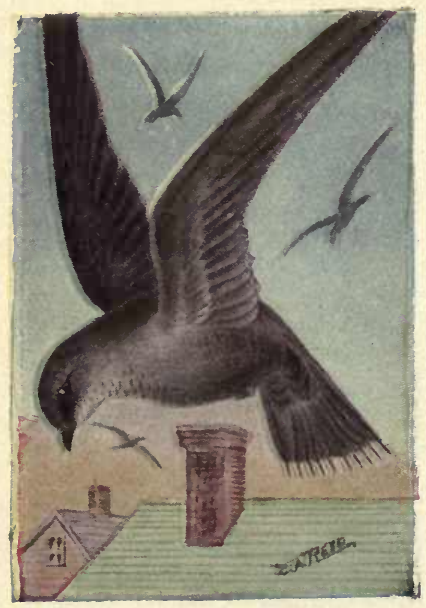

38

\section{CHIMNEY SWIFT.}

423. Chatura pelagica. $51 / 2$ inches.

Unused chimneys of old dwellings make favorite roosting and nesting places for these smoke-colored birds. They originally dwelt in hollow trees until the advent of .man furnished more convenient places, although we would scarcely consider the soot-lined brick surface as good as a clean hollow tree. Spines on the end of each tail feather enable them to hang to their upright walls, and to slowly hiteh their way to the outer world. Throughout the day numbers of them are scouring the air for their fare of insects, but as night approaches, they return to the chimney.

Note.-A continuous and not unmusical twittering uttered while on the wing and also within the depths of the chimney.

Nest.-Made of small sticks or twigs glued to the sides of a chimney and each other by the bird's saliva. The three to five white eggs are long and narrow $(.75 \times .50)$.

Range.-N. A. east of the Plains, breeding from Florida to Labrador; winters south of U. S. 


\section{WHITE-THROATED SWIFT.}

425. Aeronautes melanoleucus. $61 / 2$ inches.

This beautiful swift is one of the most graceful of winged creatures. Its flight is extremely rapid and its evolutions remarkable. They nest in communities, thousands of them often congregating about the tops of inaccessible cliffs, in the crevices of which they make their homes. No bird has a more appropriate generic name than this species-"aeronautes,". meaning sailor of the air; he is a sailor of the air and a complete master of the art.

Note.-Loud, shrill twittering, uttered chiefly while on the wing.

Nest.-Placed at the end of burrows in earthy cliffs or as far back as possible between crevices in rocks; usually in inaccessible places and as high as possible from the ground. It is a saucer-shaped structure made of vegetable materials cemented together with saliva, and lined with feathers. The four white eggs measure $.87 \times .52$.

Range.-From the eastern foothills of the Rockies to the Pacific; north to Montana and northern California

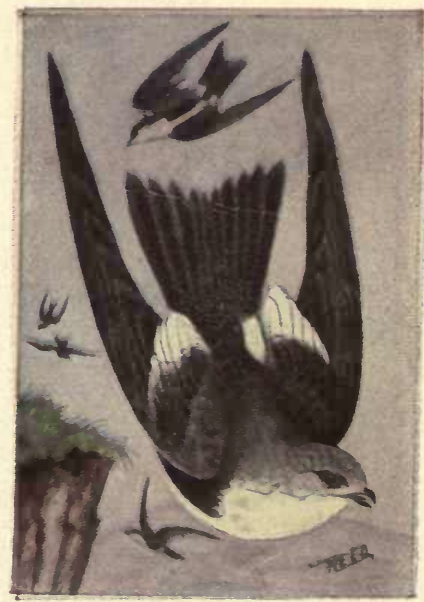




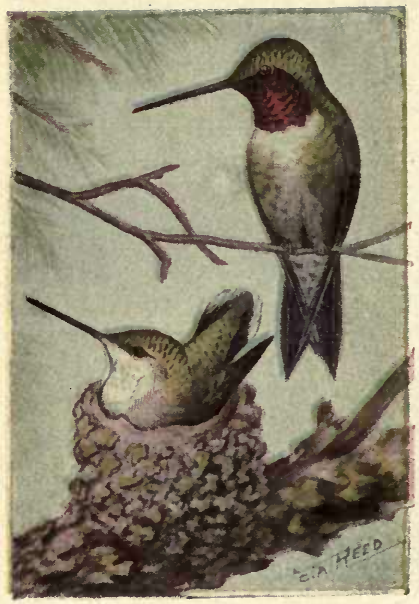

40
RUBY-THROATED HUMMINGBIRD.

428. Archilochus colubris. $3 \frac{1}{2}$ inches.

This little gem is the only one of the family found within the territory included in this book. Owners of flower gardens have the best of opportunities to study these winged jewels, on their many trips to and fro for honey, or the insects that are also attracted thereby. With whirring wings, they remain suspended before a blossom, then-buzz-and they are examining the next, with bill lost within the sweet depths. Their temper is all out of proportion to their size, for they will dash at an intruder about their moss-covered home as though they would pierce him like a bullet. Their angry twitters and squeaks are amusing and surprising, as are their excitable actions.

Nest. - A most beautiful creation of plant fibres and cobwebs adorned with lichens and resembling a little tuft of moss upon the bough on which it is placed. In June two tiny white eggs are laid $(.50 \times .35)$.

Range.-N. A. east of the Rockies, breeding from the Gulf north to Labrador and Hudson Bay; winters south of U.S. 
SCISSOR-TATLED FLYCATCHER.

443. Muscivora forficata. $141 / 2$ inches.

This pretty creature is the most graceful in appearance of the Flycatcher family, if not of the whole order of perching birds. In the southwest it is frequently known as the "Texan Bird of Paradise." Its habits are very much like those of the Kingbird; as it gracefully swings through the air in pursuit of insects, it frequently opens and shuts its scissor-like tail. They are usually found in open country or on the borders of woodland. They rarely alight on the ground, for their long tails make them walk very awkwardly, but when they are a-wing they are the embodiment of grace.

Note.-A shrill "tzip," "tzip," similar to notes of Kingbirds.

Nest.-Quite large; built of all kinds of trash, such as twigs, grasses, paper, rags, string, etc.; placed in any kind of a tree or bush and at any height. The four or five creamy white eggs are spotted with brown $(.90 \times .67)$.

Range.-Breeds from Texas north to Kansas; winters south of U. S.

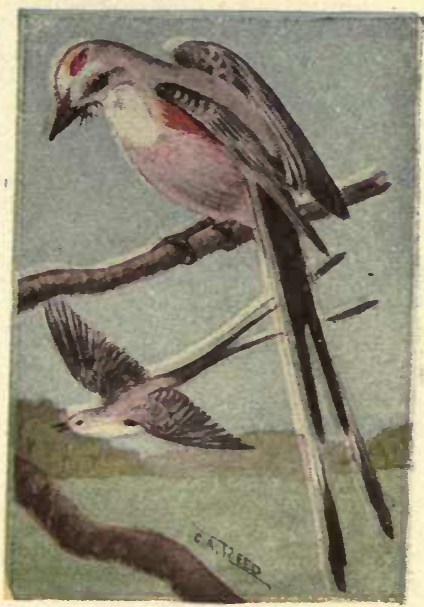




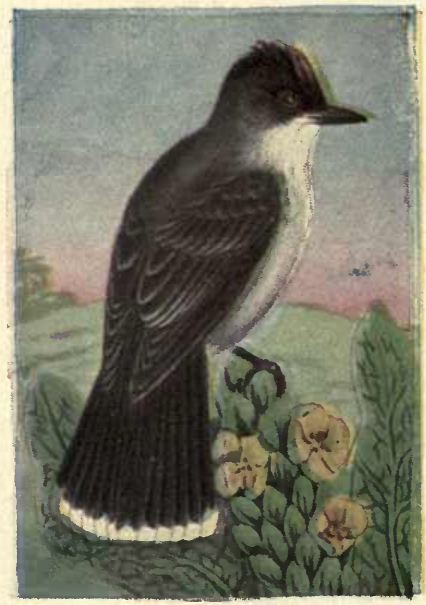

42

\section{KINGBIRD.}

444. Tyrannus tyrannus. $81 / 2$ inches.

Adults with a concealed orange crown patch; young with none. From the time of their arrival in May until they leave us in August, Kingbirds are much in evidence in farmyards and orchards. They are one of the most noisy birds, always quarreling about something, and usually coming off victorious in whatever they niay undertake. Crows are objects of hatred to them, and they always drive them from the neighborhood, vigorously dashing upon and picking them from above and often following them for a great distance. They have their favorite perches from which they watch for insects, usually a dead branch, a fence post, or a tall stalk in the field.

Note.-A series of shrill, harsh sounds like "thsee," "thsee."

Nest.-Of sticks, rootlets, grass, string, etc., placed in orchard trees or open woods at any height. Four or five creamy white eggs, specked and spotted with reddish brown $(.95 \times .70)$.

Range.-Breeds from the Gulf to southern Canada. 


\section{GRAY KINGBIRD.}

445. Tyrannus dominicensis. 9 inches.

Differs from the common Kingbird in being larger and gray above; has black ear coverts, and no white tip to tail.

Like the last species, these are very noisy and pugnacious, and rule their domains with the hand of a tyrant. After they have mated they quarrel very little among themselves, and often several may use the same lookout twig from which to dash after passing flies or moths.

Note.-A rapidly repeated, shrill shriek: "pe-che-ri," "pe-che-ri."

Nest.-Rather more shabbily built but of the same materials as those used by our common Kingbird. Placed in all kinds of trees, but more often in mangroves, where they are commonly found. Three to five pinkish-white eggs, profusely blotched with brown $(1.00 \times .72)$.

Range.-West Indies and Florida, Georgia and South Carolina. Winters in the West Indies and Central America.

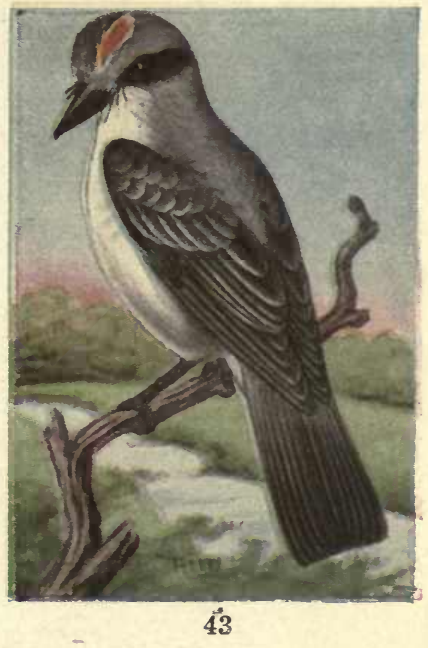




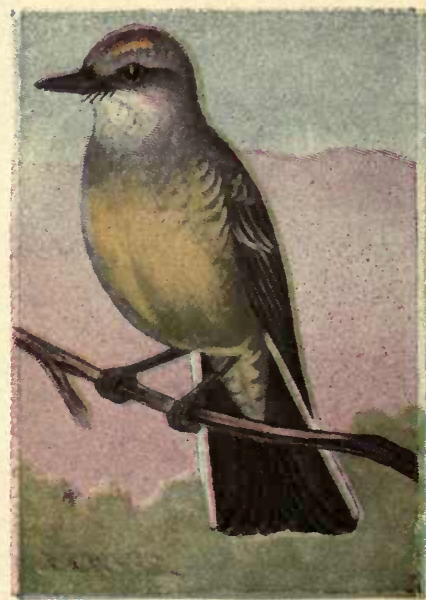

\section{ARKANSAS KINGBIRD.}

447. Tyrannus verticalis. 9 inches.

These tyrant flycatchers are abundant west of the Mis. sissippi, where they are often, and perhaps more aptly, known as the Western Kingbirds. If possible, they are even more noisy and pugnacious than the eastern species. They have a great variety of notes, all rather unpleasant to the ear. Their food, like that of the other Kingbirds, consists of moths, butterflies, ants, grasshoppers, cricketc., etc., most of which they catch on the wing.

Note.-A shrill, metallic squeak; a low twittering and a harsh, discordant scream, all impossible to print.

Nest.-Quite large and clumsily made of paper, rags, twigs, rootlets and grasses, placed in all sorts of locations, frequently in eave troughs or above windows. The eggs are creamy white, spotted with brown (.95 x .65 ).

Range.-Western United States, breeding from Texas to Manitoba and west to the Pacific; winters south of U. S. 


\section{DERBY FLYCATCHER.}

449. Pitangus sulphuratus derbianus. 101/2 inches.

This imposing flycatcher is the largest of the family that is found in North America. As usual with members of the family it is of a quarrelsome disposition, but hardly so much so as either the common or Arkansas Kingbirds. Their large, heavy bodies render them considerably less active than the smaller members of the family. On account of the size of the head and bill, they are often known as Bull-headed Flycatchers.

Notes.-Very varied, but similar in character to those of the eastern Kingbird.

Nest.-It is said to build its nest at low elevations in trees or in thorny bushes-a large structure of twigs and rubbish with an entrance on the side. The three to five eggs have a cream-colored ground and are prominently specked abcut the large end with brown (1.15 $\mathrm{x}$ $.82)$.

Kange.-A Mexican species that is fairly common in the Lower Rio Graude Valley in Texas.

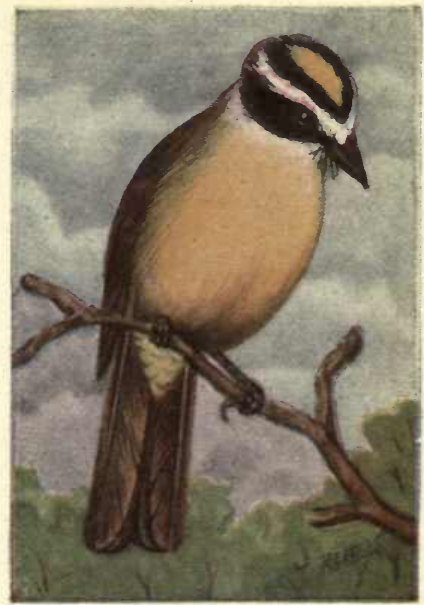




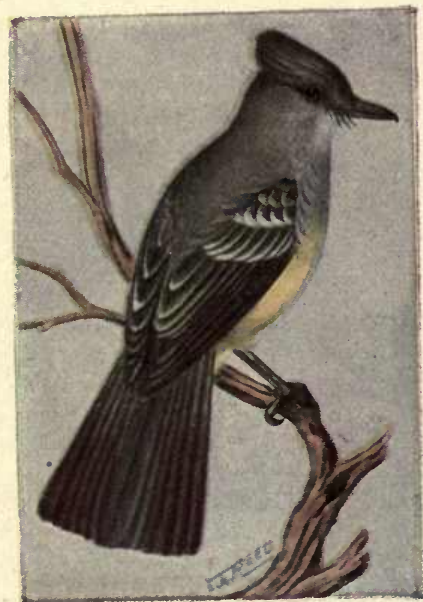

46

\section{CRESTED FLYCATCHER.}

452. Myiarchus crinitus. 9 inches.

These large flycatchers are very noisy in the mating season, but their notes are rather more musical than those of the Kingbirds. They ap. pear to be of a quarrelsome disposition, for rarely will more than one pair be found in a single piece of woods. They also frequently chase smaller birds, but never attack larger ories, as do the Kingbirds. They have a queer habit of placing a piece of snakeskin in the hole in which their nest is located, for what purpose, unless to scare away intruders, is not known, but it seems to be a universal practice.

Notes.-A clear whistle, "wit-whit," "wit-whit," repeated several times. This is the most common call; they have many others less musical.

Nest. - Of straw, etc., in holes of dead limbs. Eggs four to six in number; buffy white, streaked and blotched with brown.

Range.-Eastern N. A. from the Plains to the Atlantic, breeding north to southern Canada. 


\section{PFOEB:.}

456. Sayornis phœbe. 7 inches.

A Phœbe is always associated, in my mind, with old bridges and bubbling brooks. Nearly every bridge which is at all adapted for the purpose has its Phœbe home beneath it, to which the same pair of birds will return year after year, sometimes building a new nest, sometimes repairing the old. They seem to be of a nervous temperament, for, as they sit upon their usual iookout perch, their tails are continually twitching as though in anticipation of the insects that are sure to pass sooner or later.

Note.-A jerky, emphatic "phœ-be," with the accent on the second syllable, and still further accented by a vigorous flirt of the tail.

Nest.-Of mud, grasses and moss, plastered to the sides of beams or logs under bridges, culverts or barns. In May or june four or five white eggs are laid $(.75 \mathrm{x}$ $.55)$.

Range.-N. A. east of the Rockies, north to southern Canada; winters in southern U. S. and southward.

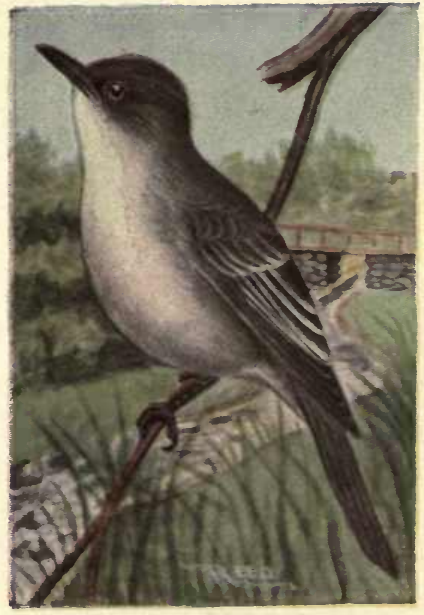




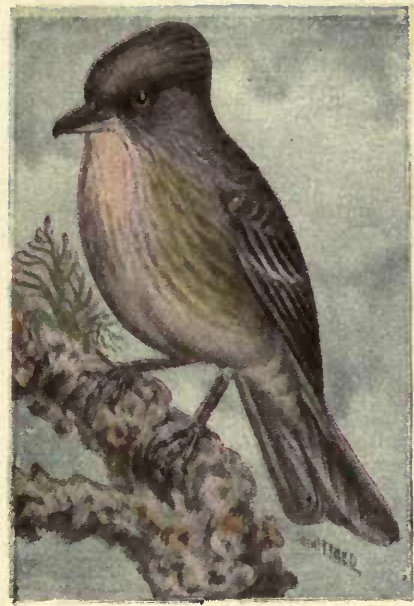

48

\section{OLIVE-SIDED FLYCATCHER.}

459. Nuttallornis borealis. $7 \frac{1}{2}$ inches.

These birds can scarcely be called common anywhere, but single pairs of them may be found, in their breeding range, in suitable pieces of woodland. I have always found them in dead pine swamps, where the trees were covered with hanging moss, making it very difficult to locate their small nests. Their peculiar, loud, clear whistle can be heard for a long distance and serves as a guide-board to their location.

Note.-A loud, clear whistle, "whip-wheeu," the first syllable short and sharp, the last long and drawn out into a plaintive ending.

Nest.-A small structure for the size of the bird, made of twigs and mosses firmly anchored to horizontal limbs or forks. Three to five eggs are laid; a rich creamy ground, spotted about the large end with brown and lavender $(.85 \times .65)$.

Range. -N. A., breeding from the latitude of Massachusetts, and farther south in mountainous regions, north to Labrador and Alaska. 


\section{WOOD PEWBE.}

461. Myiochanes virens. $61 / 2$ inches.

In life, the Pewee can best be distinguished from the larger Phøebe, with which it is often confounded, by its sad, plaintive "pe-ah-wee," "pee-wee," which is strikingly different from the brusque call of the Phœbe. Pewees are aiso found more in high, dry woods where they build their little moss-covered homes on horizontal boughs at quite a height from the ground. Like the other flycatchers they always perch on dead twigs, where their view is as little obstructed as possible.

Note.-A clear, plaintive whistle, "pe-ah-whee," "peewee."

Nest.-One of the most exquisite of bird creations, composed of plant fibres quilted together and ornamented with rock lichens; situated at varying heights on horizontal limbs, preferabiy oak or chestnut, and sometimes in apple trees in orchards. Eggs creamy white, specked with brown $(.80 \times .55)$.

Range.-U. S. from the Plains to the Atlantic and north to Manitoba and New Brunswick; winters in Central America.

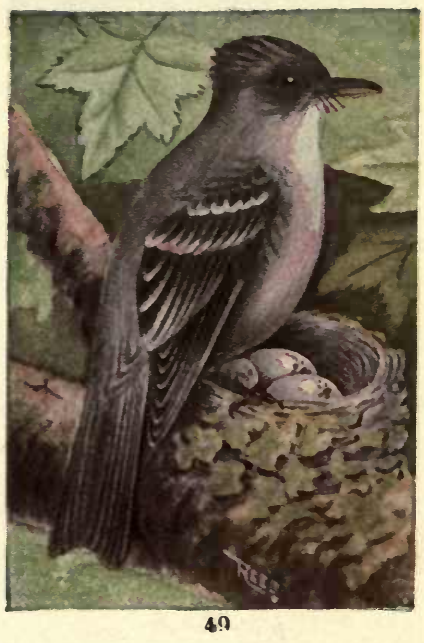




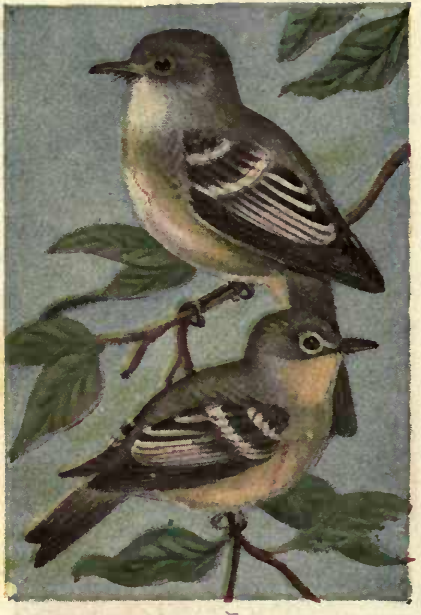

50
YELLOW-BELLIED FLYCATCHER.

463. Empidonax flaviventris. $51 / 2$ inches.

These strange little Flycatchers are found in swamps such as those usually frequented by Olive-sided Flycatchers and Parula Warblers. They are one of the few of the family to nest on the ground or very close to it. Their homes are made in the moss-covered. mounds or stumps found in these swamps.

Range.-N. A. east of the Plains north to Labrador breeding from northern U. S. northward.

\section{GREEN-CRESTED OR ACADIAN FLYCATCHER.} 465. Empidonax virescens. $51 / 2$ inches.

This bird is very similar to the last, but the lower mandible is light, and the throat and belly white. Their favorite resorts are shady woods not far from water. Here they nest in the outer branches of bushes or trees at heights of from four to twenty feet from the ground. The nests are shallow and composed of twigs and moss. Eggs creamy with brown spots.

Range.-U. S. east of Plains, breeding from the Gulf to New England and Manitoba; winters in the Tropics. 
ALDER FLYCATCHER.

466a. Empidonas trailli alnorum. 6 inches.

This species is very similar to, but larger, than the rell-known Least Flycatcher or Chebec. They are found in swampy pastures or around the edges of ponds or lakes, where they nest in low bushes.

Range.-U. S. east of the Mississippi, breeding from New York to New Brunswick.

\section{LEAST FLYCATCHER.}

467. Empidonax minimus. 51/2 inches.

Smaller than the last and with the tail slightly forked. Common everywhere in orchards, swamps or along roadsides. They are very often known by the name of "Chebec," because their notes resemble that word. Their nests are placed in upright forks of any kind of trees or bushes; they are made of plant fibres and grasses closely felted together. The eggs range from three to five in number and are creamy white, without markings; size $.65 \times .50$.

Range.-N. A. east of the Rockies, breeding from middle U. S. north to New Brunswick and Manitoba.

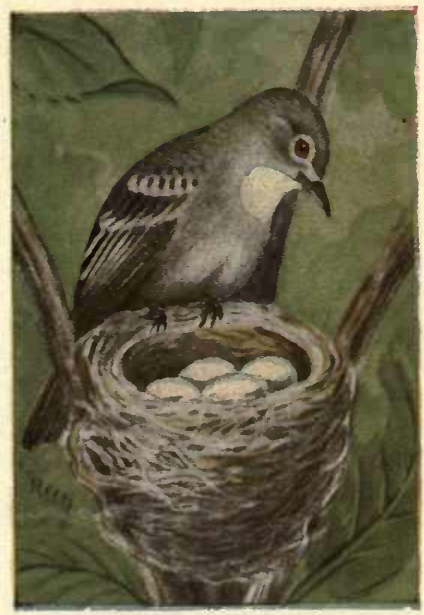




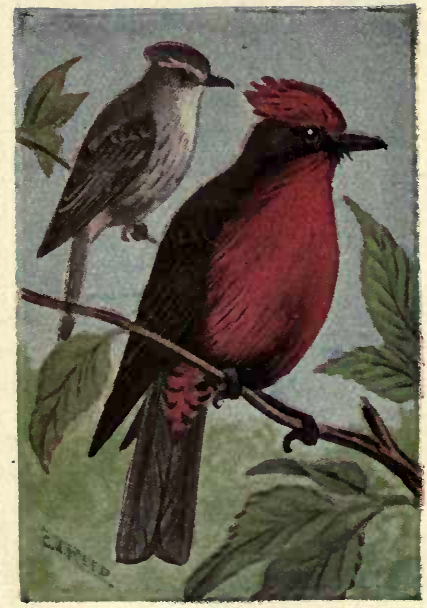

52
471. Pyrocephalus rubinus mexicanus. 6 inches.

Female with only a slight tinge of pink, where the male is brilliant vermilion.

This is the most gorgeously plumaged species of the American Flycatchers. It has all the active traits of the family and, to those who are only accustomed to the demure gray plumage of most eastern species, the first sight of this one as he dashes after an insect is a sight never to be forgotten.

Notes.-During the mating season the male often gives a twittering song while poised in the air, accompanying it by loud snapping of the mandibles.

Nest. - Saddled on limbs of trees at low elevations from the ground; composed of small twigs and vegetable fibres closely felted together and often adorned on the outside with lichens similar to the nests of the Wood Pewee. The four eggs are of a creamy-buff color with bold spots of brown and lilac, in a wreath around the large end $(.73 \times .54)$.

Range.-Mexican border of the United States, from Texas to Arizona. 
HORNED TARK.

474. Otocoris alpestris. $7 \frac{3}{4}$ inches.

This variety, which is larger than its sub-species, is only found in the U. S. in winter, but several of the sub-species are residents in our limits. During the mating season they have a sweet song that is uttered on the wing, like that of the Bobolink.

Notes.-Alarm note and call a whistled "tseet," "tseet"; song a low, sweet and continued warble.

Nest.-A hollow in the ground lined with grass; placed in fields and usually partially concealed by an overhanging sod or stone. The three to five eggs have a grayish ground color and are profusely specked and blotched with gray and brownish $(.85 \times .60)$.

Range.-Breeds in Labrador and about Hudson Bay; south in winter to South Carolina and Illinois.

Sub-species.-474b. Prairie Horned Lark (praticola). A paler form usually with the line over the eye white. found in the Mississippi Valley. 474c. Desert Horned Lark (leucolæma). Paler and less distinctly streaked above than the Prairie; found west of the Mississippi and north to Alberta.

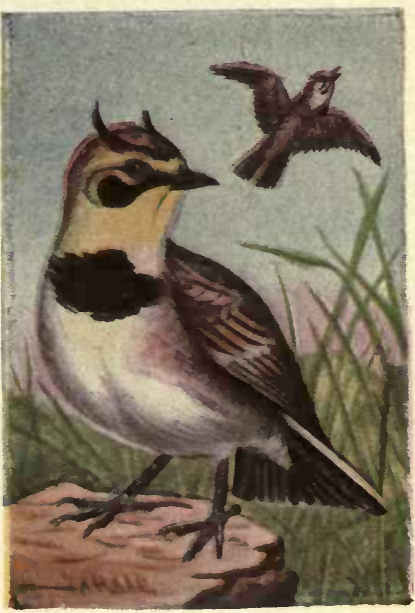




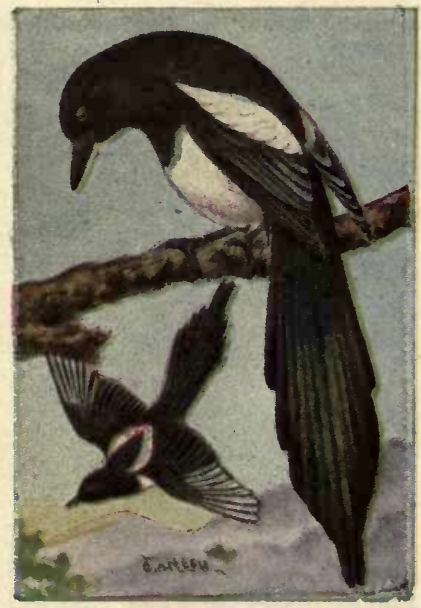

54

\section{AMERICAN MAGPIE.}

475. Pica pica hudsonia. 20 inches.

This handsome member of the Crow family is sure to attract the attention of all who may see him. He is very pert in all his actions, both in trees and on the ground, and is always ready for mischief. In a high wind their long tail often makes traveling a laborious operation for them, and at such times they usually remain quite quiet. They are very impudent and always on the lookout for something to steal; they are also very noisy and forever scolding and chattering among themselves.

Notes.-A loud, harsh "cack," "cack," and an endless variety of whistles and imitations.

Nest.-A large, globular heap of sticks placed in bushes or trees from four to fifty feet from the ground. The entrance to the nest is on one side and the interior is made of grass and mud. The four to six eggs are white, thickly specked with yellowish brown ( $1.25 \times .90)$.

Range.-Western North America, east to the Plaine and north to Alaska; resident. 


\section{BLUE JAY.}

477. Cyanocitta cristata. $11 \frac{1}{2}$ inches.

These are one of the best known and most beautiful birds that we have, but, unfortunately, they have a very bad reputation. They often rob other birds of their eggs and young as well as food and nesting material. They are very active birds and are always engaged in gathering food, usually acorns or other nuts, and hiding them away for future use.

Notes.-A two-syllabled whistle or a harsh, discordant scream. Besides these two common notes they make an endless variety of sounds mimicking other birds.

Nest.-Of twigs and sticks in bushes or low trees, preferably young pines. The four eggs are pale greenish blue specked with brown $(1.10 \times .80)$.

Range.-N. A. east of the Rockies from the Gulf to Labrador, resident in the U. S. The Florida Blue Jay (florincola) is smaller and has less white on wings and tail.

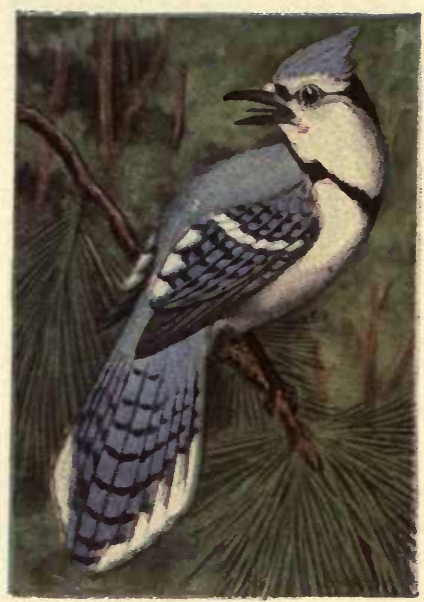




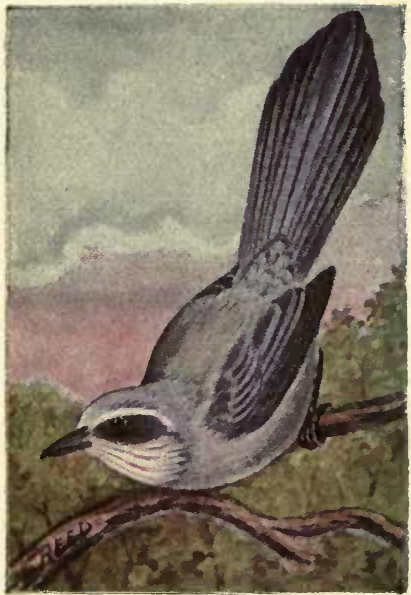

56

\section{FLORIDA JAY.}

479. Aphelocoma cyanea. $11 \frac{1}{2}$ inches.

This Jay is locally distributed chiefly in the southern parts of Florida, being found principally in scrub oaks. Like the Blue Jay, their food consists of animal matter and some seeds, berries and acorns. Their habits are very similar to those of the northern bird and their calls resemble those of our bird, too. They are rather slow in flight and pass a great deal of their time upon the grourid.

Notes.-A "jay," "jay," similar to that of the Blue Jay, and a great variety of other calls.

Nest. - In the latter part of March and in April they build their flat, nests of twigs, usually in bushes or scrub oaks, and lay three or four greenish-blue eggs, with brown spots; size $1.05 \times .80$.

Range.-Middle and scuthern portions of Florida chiefly along the coasts. 


\section{GREEN JAY.}

483. Xanthoura luxuosa glaucescens. 12 inches. These Jays are very beautiful, and we are sorry to have to admit that, like all the other members of the family, they are merciless in their treatment of smaller birds. During the summer their diet consists of raw eggs with young birds "on the side," or vice versa; later they live upon nuts, berries, insects; in fact, anything that is edible.

Notes.-Practically unlimited, being imitations of those of most of the birds in the vicinity.

Nest.- Not easily found, as it is usually concealed in dense thickets. The nests are like those of other Jays, loosely made of twigs and lined with black rootlets. The four eggs that are laid in May have a grayish ground color and are thickly spotted with several shades of brown and lilac. They measure $1.05 \times .80$.

Range.-Fairly common in the Lower Rio Grande Valley in southern Texas.

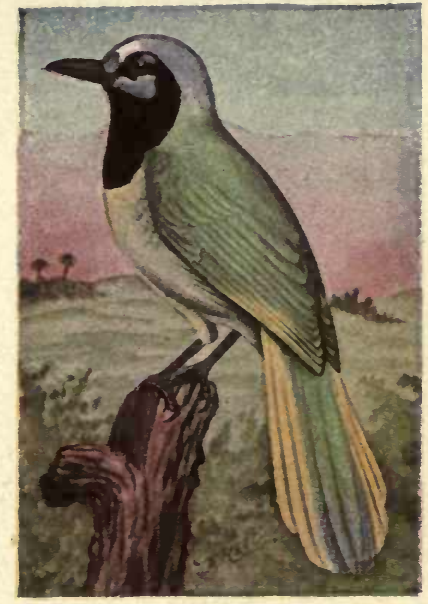

57 


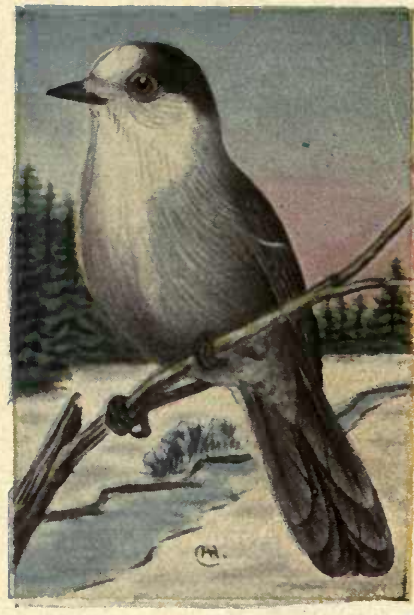

58
CANADA JAY.

484. Perisoreus canadensis. $111 / 2$ inches.

These birds are well known to hunters, trappers and campers in the northern woods. They are great friends, especially of the lumbermen, as some of the pranks that they play serve to enliven an otherwise tedious day. They seem to be devoid of fear and enter camp and carry off everything, edible or not, that they can get hold of They are called by guides and lumbermen by various names, such as Whiskey Jack, Moose Bird, etc.

Notes.-A harsh "ca-ca-ca," and various other sounds. Nest.-Usually in coniferous trees at low elevations; made of twigs, moss and feathers. The three or four eggs are gray, specked and spotted with darker (1.15 x $.80)$. They nest early, usually before the snow begins to leave the ground and often when the mercury is below zero.

Range.-Eastern North America from northern United States northward. 484c. Labrador Jay (nigricapillus), which is found in Labrador, has the black on the hind head deeper and extending forvard aloun $J$ the eye. 


\section{NORTHERN RAVEN.}

486a. Corvus corax principulis. 25 inches.

The habits of all the rayens and crows are identical and are too well known to need mention. They are all very destructive to young birds and eggs. The Raven can be known by its large size, its very large bill and lanceolate feathers on the throat. They are found in the mountains from Georgia and on the coast from Maine northwards.

\section{WHITE-NECKED RAVEN.}

487. Corvus cryptoleucus. $181 / 2$ inches.

This species has the bases of the feathers on the back of the neck white. Found in southwestern United States.

\section{AMERICAN CROW.}

488. Corvus brachyrhynchos. 19 inches.

The common Crow of North America, replaced in Florida by the very similar Florida Crow (pascuus).

\section{FISH CROW.}

490. Corvus ossifragus. 16 inches.

This small species is found on the Atlantic coast north to Massachusetts.

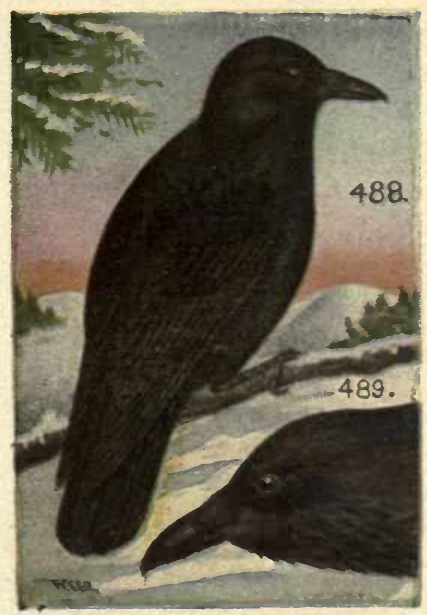




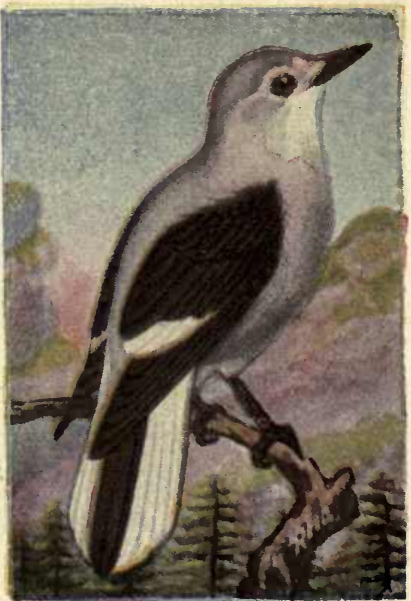

60
CLARKE NOTCRACKER.

491. Nucifraga columbiana. $12 \frac{1}{2} 2$ inches.

Clarke Crows are found abundantly in all coniferous forests on the higher mountains in their range. They are very peculiar birds, having some of the traits of Woodpeckers, but more of those of the Jays.

They are very active, very noisy and very inquisitive, sharing with the Rocky Mountain Jay the names of "Camp Robber," "Moose Bird," etc. They are great travellers and may, one season, be absent where they were abundant the preceding one.

Notes.-Various calls and imitations like those of all others of the Jay family.

Nest.-Of sticks, at high elevations on horizontal boughs of coniferous trees. The four eggs have a pale greenish-gray ground, thickly sprinkled with darker $(1.25 \times .92)$.

Range.-Mountains of western North America, casu ally east to Kansas. 


\section{STARLING.}

493. Sturnus vulgaris. $81 / 2$ inches.

Plumage metallic green and purple, heavily spotted above and below with buffy or white.

These European birds were introduced into New York a number of years ago, and are now common there and spreading to other localities in Connecticut and about New York City. They live about the streets and in the parks, building their nests in crevices of buildings and especially in the framework of the elevated railroads of the city, and less often in trees. They lay from four to six pale-blue, unspotted eggs ( $1.15 \times .85)$. How they will affect other bird life, in case they eventually become common throughout the country, is a matter of conjecture, but from what I have seen of them they are quarrelsome and are masters of the English Sparrow, and may continue their domineering tactics to the extent of driving more of our song birds from the cities.

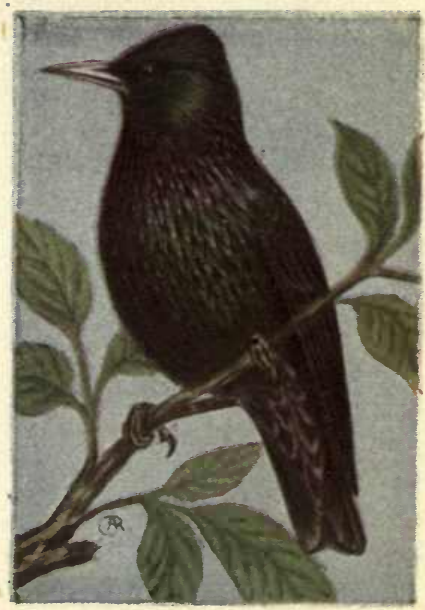




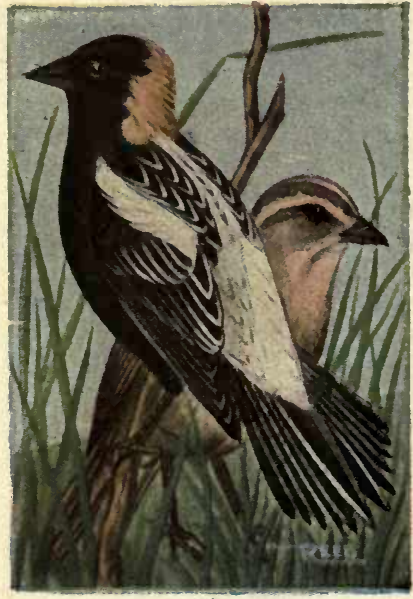

62

\section{BOBOLINK.}

494. Dolichonyx oryzivorus. $71 / 4$ inches.

Bobolinks are to be found in rich grass meadows, from whence their sweet, wild music is often borne to us by the breeze. While his mate is feeding in the grass or attending to their domestic affairs, Mr. Bobolink is usually to be found perched on the tip of a tree, weed stalk, or even on a tall blade of grass, if no other spot of vantage is available, singing while he stands guard. to see that no enemies approach. $\mathrm{He}$ is a good watchman and it is a difficult matter to flush his mate from the nest, for she leaves at his first warning.

Song.-A wild, sweet, rippling repetition of his name with many additional trills and notes. Alarm note a harsh "chah" like that of the Blackbird.

Nest.-Of grasses in a hollow on the ground, in meadows. They lay four to six eggs with a white ground color, heavily spotted, clouded and blotched with brown (.85 x .62).

Range.-N. A. east of the Rockies, breeding from New Jersey and Kansas north to Manitoba and New Brunswick; winters in South America. 


\section{- COWBIRD.}

495. Molothrus ater. $73 / 4$ inches.

Male glossy greenish black, with a krown head; fenale and young, dull gray.

Groups of these birds are often seen walking sedately about among the cows in the pasture, hence their name. They are the only birds that we have that neither make a nest of their own nor care for their young. The female slyly deposits her egg in the nest of a smaller bird when the owner is absent, leaving further care of it to its new owner. Warblers, Sparrows and Vireos seem to be most imposed upon in this manner.

Notes.-A low "chack," and by the male a liquid, wiry squeak accompanied by a spreading of the wings and tail.

Range.-U. S., chiefly east of the Rockies, breeding from the Gulf to Manitoba and New Brunswick; winters in southern U. S. A sub-species, the Dwarf Cowbird (obscurus), is found in southwestern United States; it is slightly smaller.

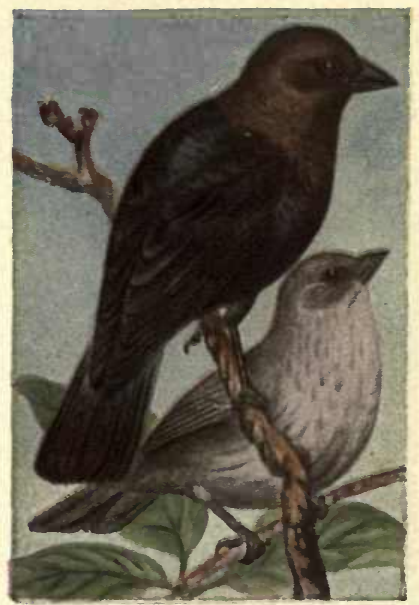

63 


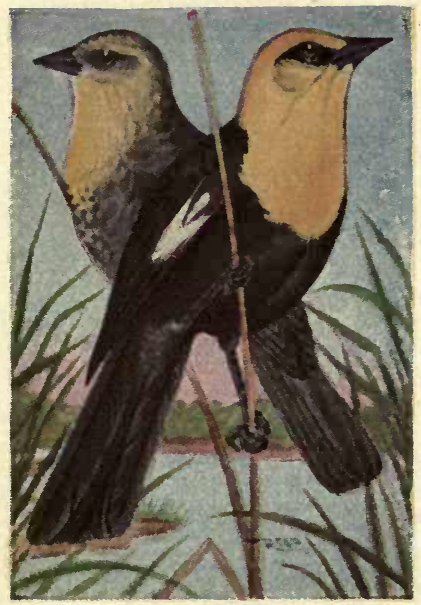

64
YELLOW-HEADED BLACKBIRD.

497. Xanthocephalus xanthocephalus. 10 inches. Male black, with head and breast bright yellow; female more brownish and with head paler and mixed with brown.

These handsome birds are common locally on the prairles, frequenting sloughs and extensive marshes and borders of lakes. They are very sociable birds and breed in large colonies, sometimes composed of thousands of birds.

Notes.-A harsh "chack," and what is intended for a song, consisting of numerous, queer sounding squeaks, they being produced during seemingly painful contortions of the singer.

Nest.-Of rushes woven around upright canes over water, in ponds and sloughs. The nest is placed at from tour inches to two feet from the water and is quite deep inside. The four to six eggs are grayish, profusely specked with pale brown $(1.00 \times .70)$.

Range.-U. S., chiefly west of the Mississippi, north to Britisin Columbia and Hudson Bay; winters on southwestern border of the $\mathrm{U}$ S. 


\section{RED-WINGED BLACKBIRD.}

498. Agelaius phoniceus. $9 \frac{1}{2}$ inches.

Male black, with scarlet and buff shoulders; female brownish black above and streaked below. Nearly all our ponds or wet meaūows have their pair or colony of Blackbirds.

Note.-A harsh cack; a pleasing liquid song, "conkerr-ee," given with much bowing and spreading of the wings and tail.

Nest.-Usually at low elevations in bushes, in swamps or around the edges of ponds, or frequently on the ground or on hummocks in wet pastures. The nest is made of woven grasses and rushes, and is usually partially suspended from the rim when placed in bushes. The three to five eggs are bluish white, scrawled, chiefly around the large end, with blackish $(1.00 \times .70)$.

Range.-East of the Rockies, breeding north to Manitoba and New Brunswick; winters in southern U. S.

Sub-species.-498b. Bahaman Redwing (bryanti). 498c. Florida Redwing (floridanus).

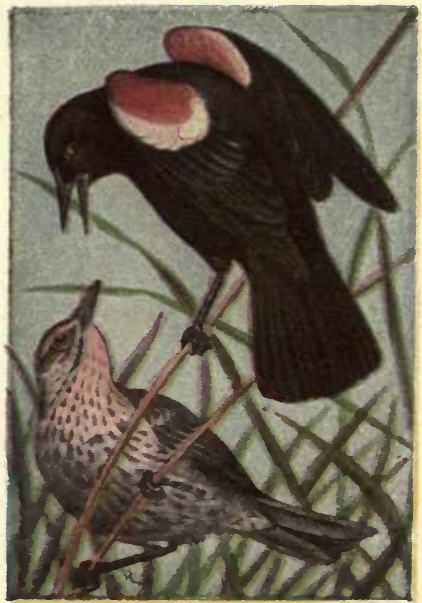




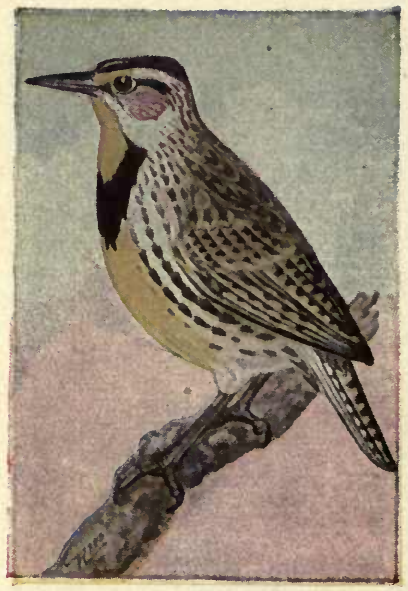

66

\section{MEADOWLARR.}

501. Sturnella magna. $103 / 4$ inches.

Meadowlarks are familiar friends of the hillside and meadow; their clear fife-like whistle is often heard, while they are perched on a fence-post or tree-top, as well as their sputtering alarm note when they fly up before us as we cross the field.

Song.-A clear, flute-like "tseeu-tseeer," and a rapid sputtering alarm note.

Nest.-Of grasses, on the ground in fields, usually partially arched over. Three to five white eggs specked with brown $(1.10 \times .80)$.

Range.-N. A. east of the Plains and north to southern Canada; winters from Massachusetts and Illinois southward.

Sub-species.-501.1. Western Meadowlark (neglecta). This race has the yellow on the throat extended on the sides; its song is much more brilliant and varied than the eastern bird. It is found from the Plains to the Pacific. 501c. Florida Meadowlark (argutula) is smaller and darker than the common. 


\section{AUDUBON ORIOLE.}

503. Icterus melanocephalus audubonii. 91/2 inches.

Within the United States, these large Orioles are found only in southern Texas. They are not uncommon there and are resident. Their notes are loud, mellow whistles like those of the other Orioles. Their nests are semi-pensile and usually placed in mesquite trees not more than ten or fifteen feet, from the ground.

\section{SCOTT ORIOLE.}

\section{Icterus parisorum. 8 inches.}

These beautiful birds are found in southwestern United States, from California to western Texas.

They are said to sing more freely than other members of the family, but the song, while loud and clear, is of short duration. Their nests, which are semi-pensile, are often places in giant yucca trees, or in vines that are suspended from cacti. The three or four eggs are pale blue, scrawled and spotted with black and lavender $(.95 \times .65)$.

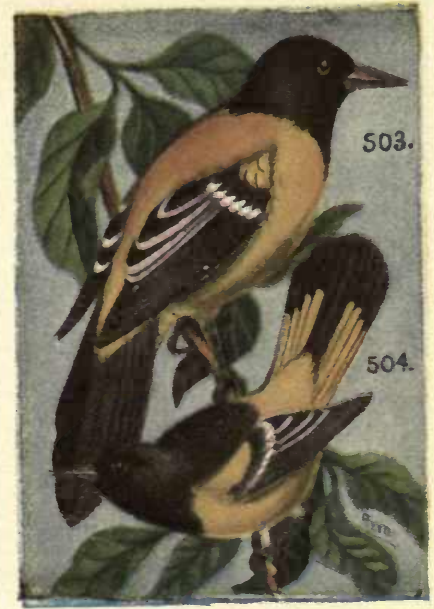




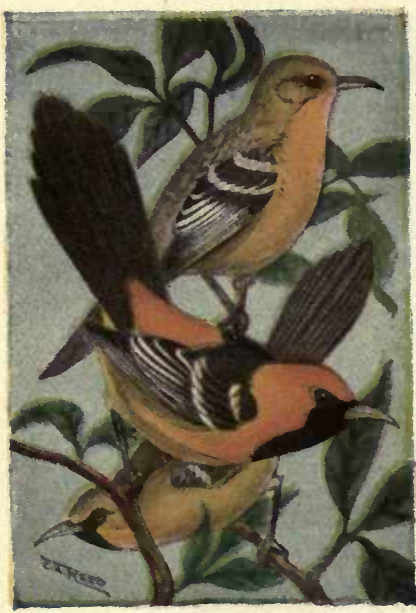

68
HOODED ORIOLE.

505. Icterus cucullatus sennetti. 8 inches.

This very brilliantly plumaged Oriole is, perhaps, the most abundant of the family in southern Texas. It is not as shy a bird as the two preceding species and is more often found in the neighborhood of houses.

With the exception of a few kinds of fruits, their food consists almost entirely of insects; all the Orioles are regarded as among our most beneficial birds.

Notes. - A harsher and more grating whistle than that of most of the Orioles.

Nest.-Usually in bunches of hanging moss, being made by hollowing out and matting the moss together and lining it with finer wiry moss. Others are placed in yucca trees, such nests being made of the fiber of the tree. Eggs dull white, scrawled about the large end with black and lavender $(.85 \times .60)$.

Range.-Found only in southern Texas. A sub. species (nelsoni) is found in New Mexico, Arizona and southern California. 
ORCHARD ORIOLE.

506. Icterus spurius. $71 / 4$ inches.

Male chestnut and black; female dull yellowish and gray; young male, second year, like female, but with black face and throat. These Orioles are usually found in open country and, as their name suggests, have a preference for orchards. They are also found abundantly in shrubbery along streams and roadsides. They feed chiefly upon worms, caterpillars, beetles, grasshoppers, etc., and are one of the most beneficial birds that we have.

Song.-A rich, loud and rapid warble, cheery and pleasing but impossible to describe; a chattering note of alarm.

Nest. - A beautiful basket of grasses woven into a deeply cupped ball and situated in forks of trees or bushes; often they are made of green grasses. Four to six white eggs, specked, scrawled and spotted with black and brown $(.80 \times .55)$.

Range.-U. S. east of the Plains, breeding from the Gulf to Massachusetts and Michigan; winters in Central America.

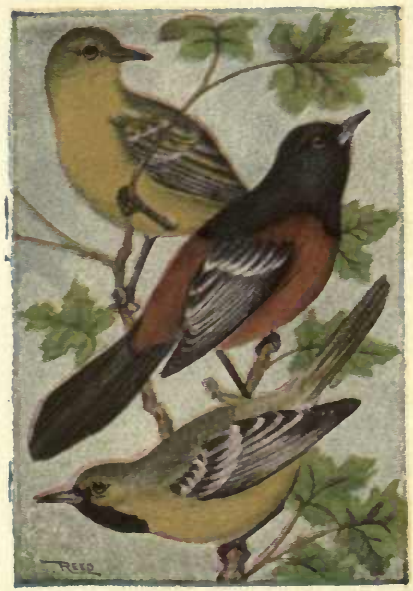

69 


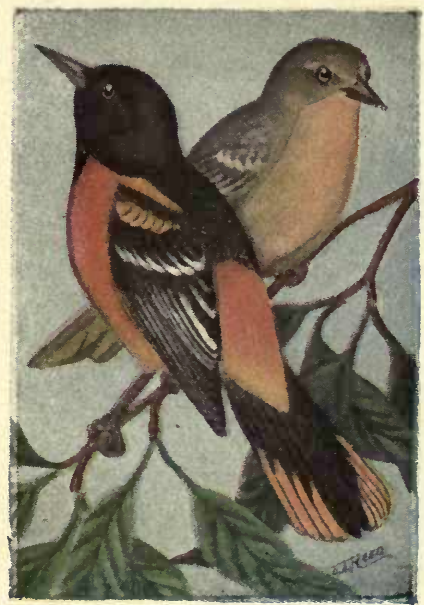

70
BALTIMORE ORIOLE.

507. Icterus galbula. 71/2 inches.

Male orange and black; female dull yellowish and gray.

They are sociable birds and seem to like the company of mankind, for their nests are, from choice, built as near as possible to houses, often being where they can be reached from windows. As they use a great deal of string in the construction of their nests, children often get amusement by placing bright-colored pieces of yarn where the birds will get them, and watch them weave them into their homes.

Song.-A clear, querulous, varied whistle or warble; call, a plaintive whistle.

Nest.-A pensile structure, often hanging eight or ten inches below the supporting rim, and swaying to and fro with every breeze. They lay five or six white eggs, curiously scrawled with blackish brown $(.90 \times .60)$.

Range. $-\mathrm{N}$. A. east of the Rockies and breeding north to New Brunswick and Manitoba. Winters in Central America. 


\section{RUSTY BLACKBIRD.}

510. Euphagus carolinus. $91 / 2$ inches.

Male glossy black; female grayish; both sexes is winter with most of the head and breast feathers tipped with rusty. In the United States we know these birds chiefly as emigrants; but a few of them remain to breed in the Northern parts. Their songs are rather squeaky efforts, but still not unmusical. These birds are found east of the Rockies.

\section{BREWER BLACKBIRD.}

510. Euphagus cyaneocephalus. 10 inches.

Male with a glossy purplish head and greenish-black body; female grayish brown. This is the Western representative of the preceding; it is most abundant west of the Rockies, but is also found on the Plains. Its distribution is not so northerly and it nests commonly in its United States range. Their eggs are whitish, very profusely spotted and blotched with various shades of brown (1.x.75):

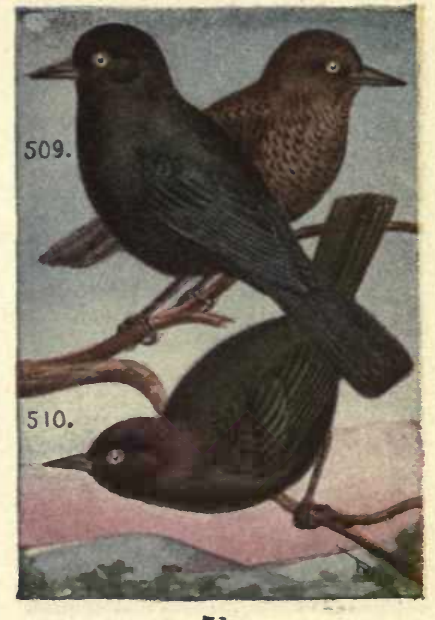




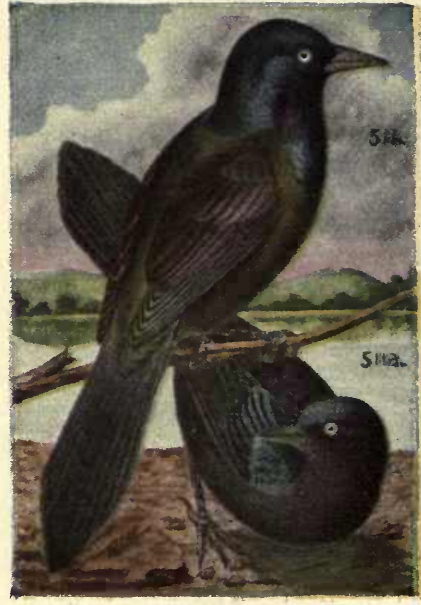

\section{PURPLE GRACKLE.}

511. Quiscalus quiscula. 12 inches.

Male with purple head and greenish back; female brownish gray. All the Grackles are very similar in appearance, the colors varying with different individuals of the same species. Their habits are alike, too, and I consider them one of the most destructive of our birds.

Notes.-A harsh "tchack," and a squeaky song.

Nest.-Of sticks and twigs, usually in pines in the North and bushes in the South. Four eggs, pale bluish gray with black scrawls $(1.10 \times .80)$.

Range.-Eastern U. S., breeding north to Mass.

Sub-species.-511a. Florida Grackle (aglæus), slightly smaller. 511b. Bronzed Grackle (æneus, with a purple head and usually a brassy back. Eastern U. S. breeding north to Labrador and Manitoba.

\section{BOAT-TAILED GRACKLE.}

513. Megaquiscalus major. 15 inches.

Similar in color to the last but much larger, and hav ing the same habits. Eggs also larger $(1.25 \times .95)$. Southeastern U. S. The Great-tailed Grackle (macrourus). found in Texas, is still larger. 


\section{EVENING GROSBEAR.}

514. Hesperiphona vespertina. 8 inches.

Female paler and with white on upper tail coverts. As would be judged from the large bills that these birds have, their food consists almost entirely of seeds, with occasionally a few berries and perhaps insects. In certain localities they are not uncommon, but, except in winter, they are rare anywhere in the U. S. and east of the Mississippi they can only be regarded as accidental even in winter. They have been taken several times in Massachusetts. In winter they usually travel about in small bands, visiting localities where the food supply is the most abundant.

Song.-A clear Robin-like whistle; call, a short whistle.

Nest.-A flat structure of twigs and rootlets placed at low elevations in trees or bushes. Four eggs, greenish white, spotted with brown $(.90 \times .65)$.

Range.-Breeds in mountains of western British America and northwestern U. S. South and east in winter to the Mississippi and rarely farther.

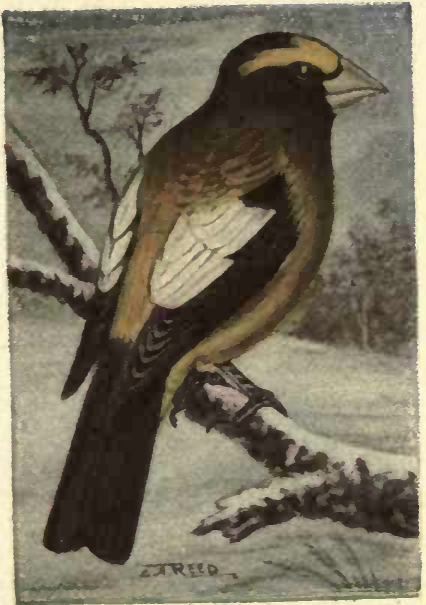

73 


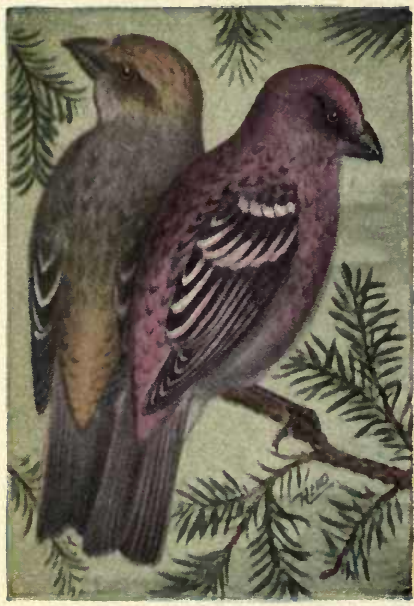

74

\section{PINE GROSBEAK.}

515. Pinicola enucleator leucura. $81 \frac{1}{2}$ inches. Male rosy red; female gray and yellowish. These pretty birds visit us every winter, coming from Canada and northern New England, where they are found in summer. They are very fearless birds and might almost be regarded as stupid; when they are feeding you can easily approach within a few feet of them, and they have often been caught in butterfly nets. They may, at times, be found in any kind of trees or woods, but they show a preference for small growth pines, where they feed upon the seeds and upon seeds of weeds that project above the snow.

Song.-A low sweet warble; call, a clear, repeated whistle.

Nest.-In coniferous trees, of twigs, rootlets and strips of bark; eggs three to four in number, greenish blue spotted with brown and lilac $(1.00 \times .70)$.

Range.-Breeds in eastern British America and northern New England; winters south to New York and Ohio. Several sub-species are found west of the Rockies. 


\section{PURPLE FINCH.}

517. Carpodacus purpureus. 61/4 inches.

Male dull rosy red; female streaked brownish gray.

These beautiful songsters are common in the northern tier of states and in Canada. In spring the males are usually seen on, or heard from, tree tops in orchards or parks, giving forth their glad carols. They are especially musical in spring when the snow is just leaving the ground and the air is bracing. After family cares come upon them, they are quite sllent, the male only occasionally indulging in a burst of song.

Song.-A loud, long-continued and very sweet warble; call, a querulous whistle.

Nest.-Of strips of bark, twigs, rootlets and grasses, placed at any height in evergreens or orchard trees. The eggs resemble, somewhat, large specimens of those of the Chipping Sparrow. They are three or four in number and are greenish blue with strong blackish specks $(.85 \times .65)$.

Range. $-\mathrm{N}$. A. east of the Rockies, breeding from Pennsylvania and Illinois northward; winters throughout the United States.

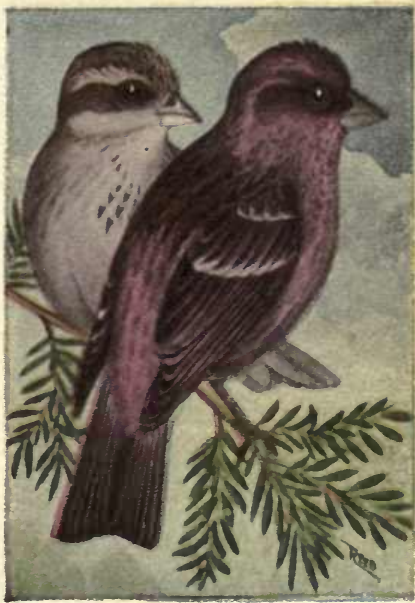




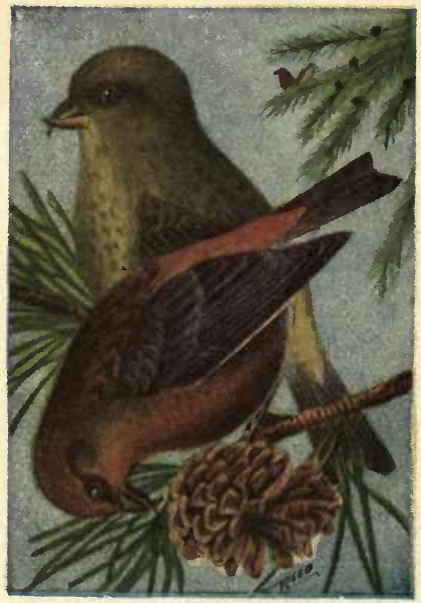

76
AMERICAN CROSSBILL.

521. Loxia curvirostra minor. 6 inches.

These curious creatures appear in flocks on the outskirts of our cities every winter, where they will be found almost exclusively in coniferous trees. They cling to the cones, upon which they are feeding, in every conceivable attitude, and a shower of seeds and broken cones rattling through the branches below shows that they are busily working. They are very eccentric birds and the whole flock of ten takes flight, without apparent cause, only to circle about again to the same trees. The flute-like whistle that they utter when in flight sounds quite pleasing when coming from all the individuals in the flock.

Song.-A low twittering; call, a short, flute-like whistle.

Nest.-In coniferous trees, of spruce twigs, shreds of bark and some moss or grass. The three or four eggs are greenish white spotted with brown $(.75 \times .55)$.

Range.-Breeds from northern New England northward and westward, and south in mountains to Georgia; winters in the northern half of the U.S. 


\section{WHITE-WINGED CROSSBILI.}

522. Loxia leucoptera. 6 inches.

Male, rosy; female, with yellowish.

This species seems to be of a more roving disposition, and even more eccentric than the last. They are not nearly as common and are usually seen in smaller flocks; occasionally one or two individuals of this species will be found with a flock of the American Crossbills, but they usually keep by themselves. While they may be seen in a certain locality one season, they may be absent for several seasons after, for some reason or other. They feed upon the seeds of pine cones, prying the cones open with their peculiar bills. last.

Notes.-Do not differ appreciably from those of the

Nest.- The nesting habits of this species are like those of the last, but the eggs differ in being slightly larger and in having the markings of a more blotchy character $(.80 \times .55)$.

Range.-Breeds from the northern parts of the northern tier of states northward. Winters in the northern half of the U. S.

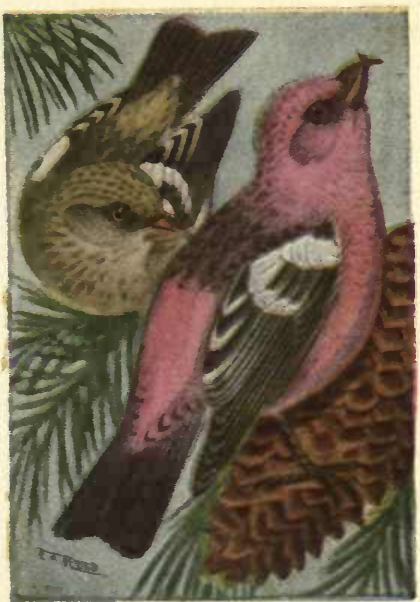




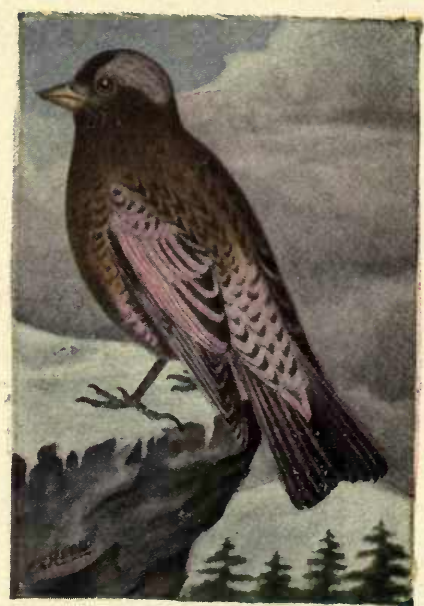

78

\section{GRAY-CROWNED LEUCOSTICTE.}

524. Leucosticte tephrocotis. $61 / 2$ inches.

Female similar to, but duller colored than the male. All the members of this genus are western and northern, this one only being found east of the Rockies and then only in winter, when it occasionally is found east of the Mississippi. They wander about in rocky mountainous regions, feeding upon seeds and berries. They are very restless and stop in a place but a short time before flying swiftly away, in a compact flock, to another feeding ground.

Note.-An alarm note of a short, quick whistle.

Nest.-Built on the ground, usually beside a rock or in a crevice; composed of weeds and grass, lined with finer grass. They lay three or four unmarked white eggs in June.

Range.-Western U. S., breeding in the higher moun. tain ranges; in winter sometimes wandering east to the Mississippi. 


\section{REDPOLL.}

528. Acanthis linaria. $51 / 4$ inches.

Male with a rosy breast; female without.

In winter these northern birds may be found in locks gathering seeds from weeds by the roadside and stone walls. Their actions greatly resemble those of our Goldfinch, but their flight is more rapid.

Song.- Strong, sweet and canary-like.

Nest.-At low elevations in bushes or trees; eggs three to five, pale greenish blue with brown specks.

Range.-Breeds in the extreme north; winters south to northern U.S.

Sub-species.-528a. Holboell Redpoll (holboelli), slightly larger. 528b. Greater Redpoll (rostrata), larger and darker.

\section{GREENLAND REDPOLL.}

527. Acanthis hornemannii. 6 inches.

'A larger and much whiter species found in Greenland and migrating to Labrador in winter. 527b. Hoary Redpoll (exilipes), smaller and darker, but still lighter than the Redpoll; winters south to Massachusetts.

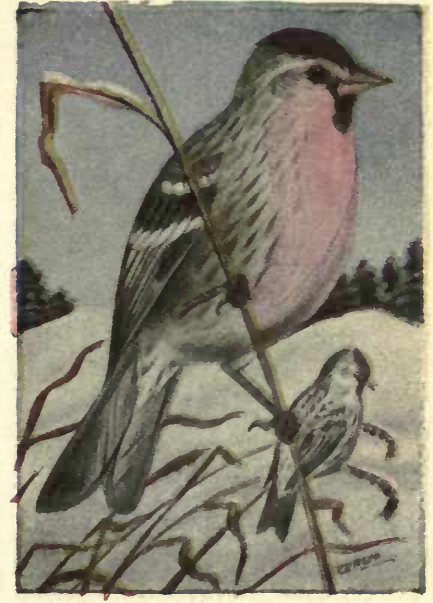

79 


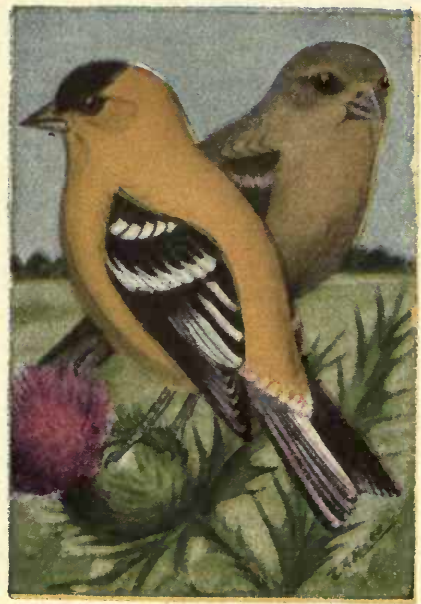

\section{AMERICAN GOLDFINCH.}

529. Astragalinus tristis. 51/4 inches.

These beautiful little creatures are often known as Thistle-birds and Wild Canaries, the former name because they are often seen on thistles, from the down of which their nests are largely made, and the latter name because of the sweet canary-like song. Their flight is a peculiar series of undulations accompanied by an intermittent twitter. They are very sociable and breed usually in communities as well as travel in flocks in the winter. Their food is chiefly of seeds and they often come to gardens in fall and winter to partake of sunflower seeds, these flowers often being raised for the sole purpose of furnishing food for the finches in the winter.

Song.-Sweet, prolonged and canary-like; call, a musical "tcheer," and a twittering in flight.

Nest.-Of thistle down, plant fibres and grasses, in forks of bushes, most often willows or alders near water. Four or five unmarked, pale bluish eggs.

Range. -N. A. east of the Rockies; breeds from Vir ginia and Missouri north to Labrador; winters in U. S. 


\section{WESTERN GOLDEINCH.}

530. Astragalinus psaltria. $41 / 4$ inches.

Cap, wings and tail black; sides of head and back greenish. Female much duller and with no black in the crown. These little Goldfinches are very abundant throughout the West. Their flight is undulatory like that of the preceding, and all their habits are very similar. They spend the winter in bands, roving about the country, feeding on weed seeds; in summer they repair. either in small bands or by single pairs, to the edges of swamps or woodland near water, where they construct their compact homes in the forks of bushes. Their eggs are pale blue like those of the American Goldfinch, but of course are much smaller $(.62 \times .45)$. They are laid in May or June, or even earlier in the western portions of their range.

Song.-Sweet and musical, almost like that of the last species.

Range.-Western United States from the Plains to the Pacific, being abundant west of the Rocky Mountains.

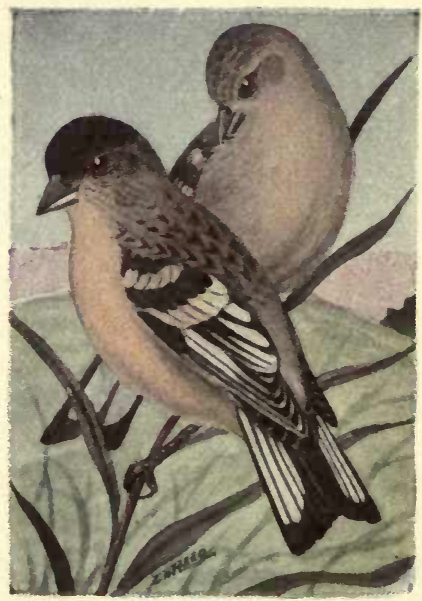

81 


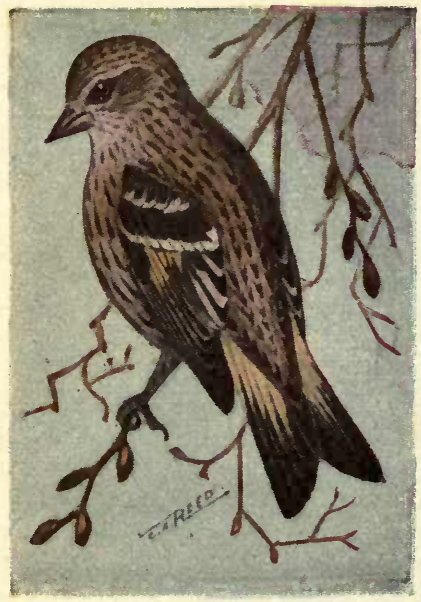

82

\section{PINE FINCH OR SISKIN.}

533. Spinus pinus. 5 inches.

These are also northern birds, being found in the $U$. S., with the exception of the extreme northern parts, only in winter and early spring. Their habits are just like those of the Goldfinches, for which species they are often mistaken, as the latter are dull-colored in winter. Their song and call-notes are like those of the Goldfinch, but have a slight nasal twang that will identify them at a distance, after becoming accustomed to it. They are often seen hanging head downward from the ends of branches as they feed upon the seeds or buds, and when thus engaged they are very tame.

Song.- Quite similar to that of the Goldfinch.

Nest.-In coniferous trees at any elevation from the ground. They are made of rootlets and grasses, lined with pine needles and hair; the three to five eggs are greenish white, speckea with reddish brown $(.65 \times .45)$.

Range.-North America, breeding northward from the northern boundary of the U. S. and farther south in mountain ranges; winters throughout the U. S. 


\section{SNOWFLAKE.}

534. Plectrophenax nivalis. 7 inches.

Adults in summer black and white; in winter, washed with brownish.

When winter storms sweep across our land, these birds blow in like true snowflakes, settling down upon hillsides and feeding upon seeds from the weed stalks that are sure to be found above the snow somewhere. They are usually found in large flocks, and are very restless, starting up, as one bird, at the slightest noise, or continually wheeling about from one hill to another, of their own accord.

Song.-A low twittering while feeding and a short whistle when in flight.

Nest. - Of grass and moss lined with feathers and sunk in the spagnum moss with which much of Arctic America is covered. Three to five eggs, pale greenish white, specked with brown. Size $.90 \times .65$.

Range.-Breeds from Labrador and Hudson Bay northward; winters in northern United States.

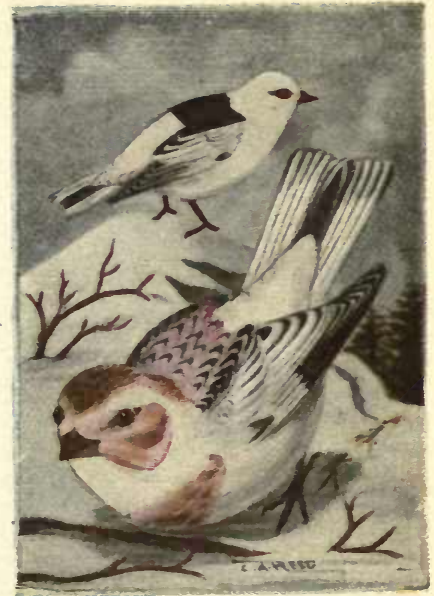




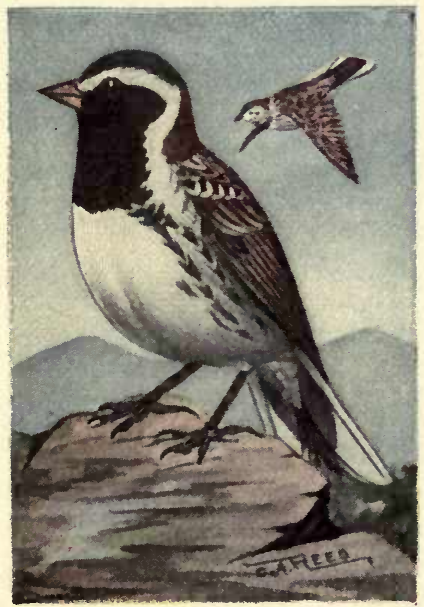

84
IAPLAND LONGSPUR.

536. Calcarius lapponicus. $61 / 4$ inches.

Male in summer with black crown and throat, and chestnut nape; female similar but duller; winter plumage, with feathers of head and neck tipped with grayish so as to conceal the bright markings.

As indicated by its name, this is a Northern species, which spends the cold months in northern U. S., traveling in flocks and resting and feeding on side hills, often wish Snowflakes, or on lower ground with Horned Larks.

Song.-A sweet trill or warble, frequently given while in flight; call, a sharp chip.

Nest.-Of mosses, grasses and feathers placed on the ground in tussocks or on grassy hummocks. In June and July they lay from four to six eggs having a grayish ground color, which is nearly obscured by the numerous blotches of brown and lavender $(.80 \times .60)$.

Range.-Breeds from Labrador northward and winters south to South Carolina and Texas. A sub-species is found in the West. 


\section{SMITH LONGSPUR.}

537. Calcarius pictus. $61 / 2$ inches.

Male in summer with the underparts buffy and sides of head marked with black; female, and male in winter, much duller with all bright markings covered with a brownish-gray wash.

Like the last species, these are Arctic birds found, in winter, on the plains and prairies of middle U. S. They are rarely found within our limits when in their beautiful spring plumage. They are most always found in company with the following species feeding upon seeds, buds and small berries.

Song.-A sweet warble rarely heard in the United States; a clear "cheer-up" constantly uttered while on the wing.

Nest.-Of grasses, weeds and moss, lined with feathers; located on the ground in similar locations to those of the last species. The four or five eggs are similar to those of the last but lighter $(.80 \times .60)$.

Range.-Breeds about Hudson Bay and northward; winters in middle United States.

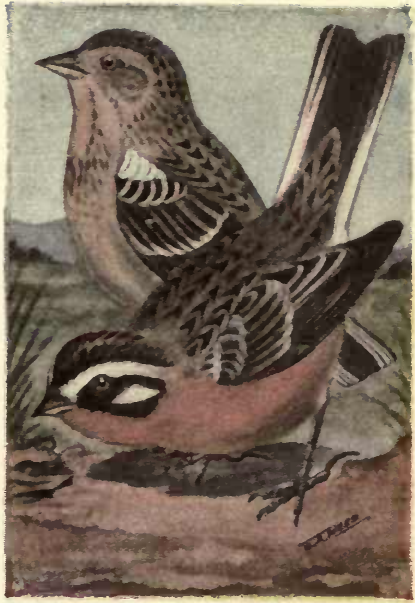

85 


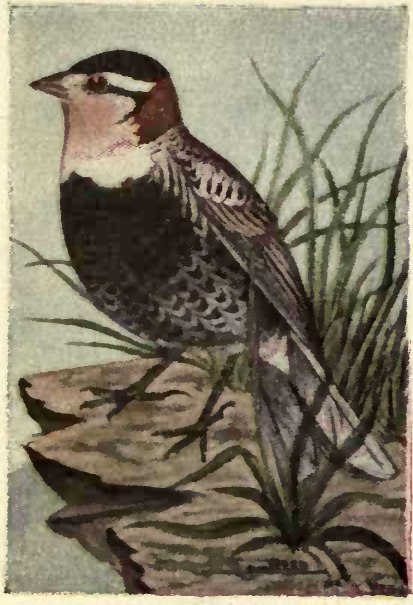

86
CHESTNUT-COLLARED LONGSPUR.

538. Calcarius ornatus. $61 / 4$ inches.

Male in summer with a black breast and crown, and chestnut nape; female, and male in winter, much duller and with all bright markings covered with grayish.

Unlike the preceding Longspurs, these are constant residents in the greater part of the Western Plains, in some localities being classed as one of the most abundant birds. They have a short, sweet song that, in springtime, is frequently given as the bird mounts into the air after the fashion of the Horned Larks. They commonly feed about ploughed fields, along the edges of which they build their nests.

Song.-A short, sweet trill; alarm note a sharp chip and call note a more musical chirp.

Nest.-Of fine grasses, placed on the ground in open prairies or along the edges of cultivated fields, often being concealed beside a tussock; their four or five eggs are clay color marked with reddish brown and lavender $(.75 \times .55)$.

Range.-Breeds in the Great Plains from Kansas and Colorado north to Manitoba; winters south to Mexico. 


\section{M'COWN IONGSPUR.}

539. Rhynchophanes mccovonii. 6 inches.

Male with a black crown and patch on breast, and chestnut shoulders; female, and male in winter, dull colored with all bright markings obscured by brownish gray.

These are also common birds on the plains of middle U. S., but perhaps not so much so as the last species, with which species they are often found breeding. These finches show their close relationship to the famous Skylark of Europe by frequently indulging in the same practice of soaring aloft and descending on set wings, rapturously uttering their sweet song.

Song.-A shrill, twittering warble; call a musical chirp.

Nest.-A neat cup of grasses in a hollow in the ground on prairies or in fields. Their four to six eggs are dull whitish clouded with brownish, the marking not being as distinct as in those of the last species $(.75 \times .55)$.

Range.-Breeds on the Great Plains from Kansas norn to Saskatchewan; winters south to Mexico

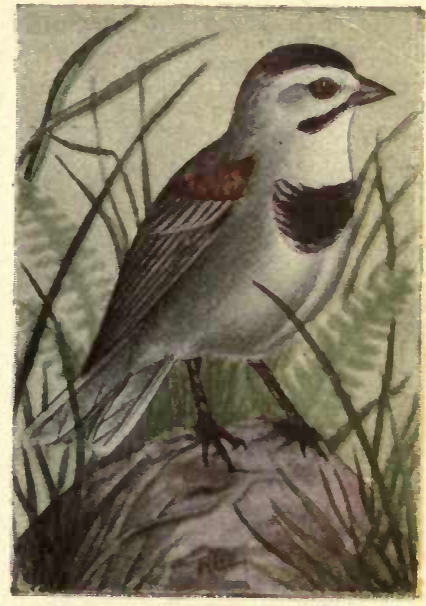

87 


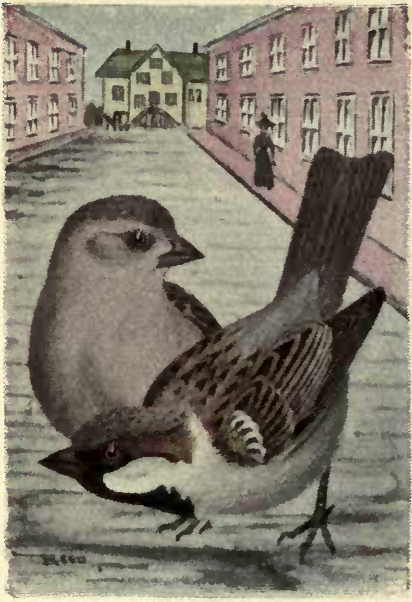

89
ENGLISH SPARROW.

*** Passer domesticus. 61/4 inches.

These street urchins were introduced into our country from Europe about 1850, and have since muitiplied and spread out so that they now are found in all parts of our land from the Atlantic to the Pacific. Heretofore they have confined themselves chiefly in the immediate vicinity of the larger cities and towns, but it is now noted with alarm that they are apparently spreading out into the surrounding country. They are very hardy creatures, able to stand our most rigorous winters. They are fighters and bullies from the time they leave the egg, and few of our native birds will attempt to live in the neighborhood with them.

Notes.-A harsh, discordant sound, which they commence early in the morning and continue until night.

Nest.-Of straw and rubbish piled behind blinds, in the tops of electric lights or crevices of buildings, and sometimes large, unsightly heaps of straw in trees. Tley raise three or four broods a year and in ali seasons; five to seven whitish eggs scratched with black.

Range.-Whole of $\mathrm{U}, \mathbf{S}$. and southern Canaria. 


\section{VESPER SPARROW.}

540. Pocectes gramineus. 6 inches.

The chestnut shoulders and white outer tail feathers distinguish this from any other of our Sparrows.

The name Vesper Sparrow is given this bird because of its habit of tuning up along towards evening; it is perhaps more often known as the "Bay-wiinged Sparrow" or "Grass Finch."

They are found chiefly in dry pastures or along dusty roadsides, where they start from the ground in front of us, their white tail feathers showing prominently as they fly, so that there will be no mistake as to their identity.

Song.-A clear, ascending series of whistles, given from a fence post or bush top; call, a sharp chirp.

Nest.-Of grasses in weedy fields or pastures; four or five whitish eggs marked and blotched with brownish $(.80 \times .60)$.

Range.-Eastern N. A. from Virginia to southern Canada; winters in southern U. S. The similar Western Vesper Sparrow (confinis) is found from the Plains to the Pacific coast ranges.

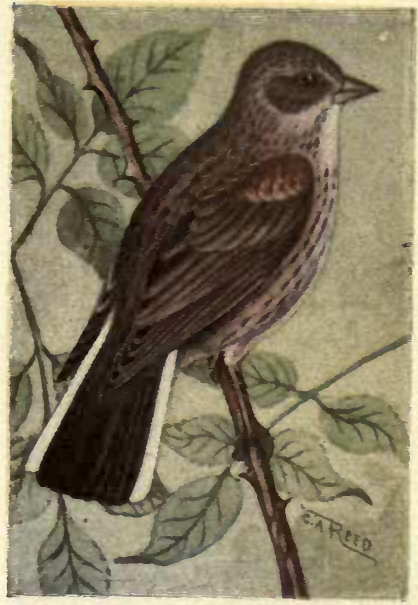

89 


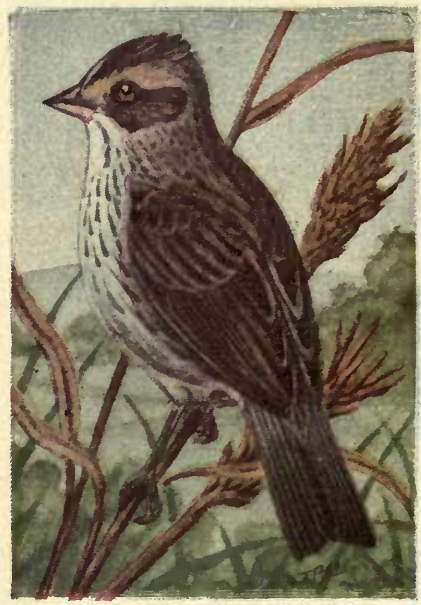

IPSWICH SPARROW.

541. Passerculus princeps. 61/4 inches.

This species is larger and paler colored, but very sim. ilar to the more common and better known Savanna Sparrow. Its habits are the same. It breeds on Sable Island, Nova Scotia, and winters along the Atlantic coast to Virginia.

SAVANNAH SPARROW.

542a. Passerculus sandwichensis savanna. 51/2 inches. Breast and sides streaked with brownish, and yellow before the eye and also on bend of wing.

These finches are very abundant in eastern U. S. during migrations and a few remain in the northern parts through the summer.

Song.-A weak trill or twitter; a short chip.

Nest.-Of grasses in hollows in the ground and concealed by grass or weeds. The four grayish eggs are spotted with brown $(.75 \times .55)$.

Range.-Winters in southern U. S.; breeds from northern U. S. northward. 542b. Western Savanna Sparrow (alaudinus) is found from the Plains west to the coast ranges. It is slightly paler. 


\section{BAIRD SPARROW.}

545. Ammodramus burriti. 5\%/4 inches.

Crown and nape brownish yellow streaked with black; underparts white streaked on the throat, breast and sides with blackish; tail slightly forked and the feathers pointed.

In summer the western plains and prairie ring with the tinkling songs of these little Sparrows; they are especially abundant in Dakota and Montana.

\section{GRASSHOPPER SPARROW.}

546. Ammodramus savannarum australis. $5 \frac{1}{2}$ inches. Crown blackish with a central buffy stripe; nape brown and gray; sides of head, breast and flanks, buffy without streaks.

Song.-A weak, insect-like "zee-e-e-e-e."

Nest.-A grass-lined hollow in a field, with the top arched over so as to keep off the sun and conceal the eggs. In June four or five white, brown-specked eggs are laid $(.75 \times .55)$.

Range.-U. S. east of the Rockies; winters in southern U. S.

546b. Florida Grasshopper Sparrow (floridanus), a

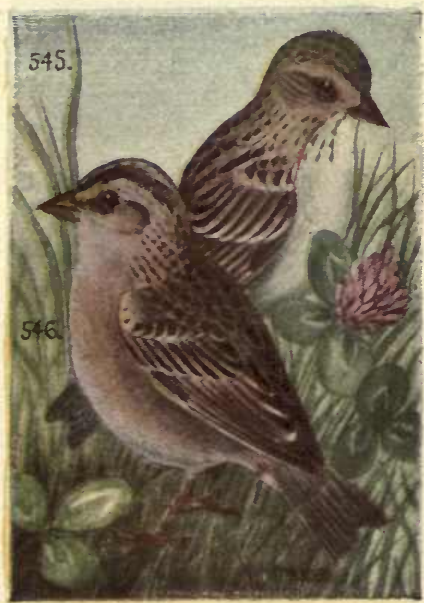




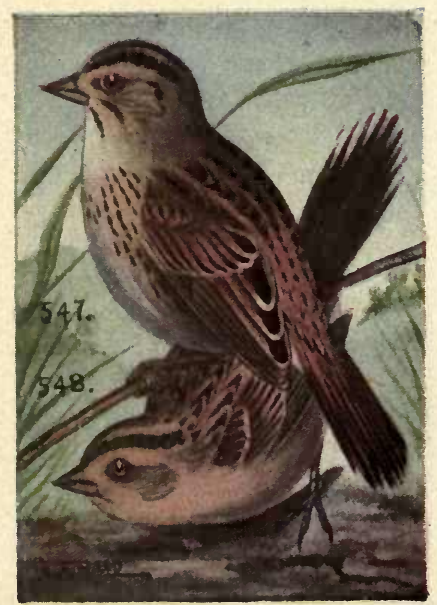

a)

\section{HENSLOW FPARROW.}

547. Passerherbulus henslowii. 5 inches.

Crown and nape greenish, streaked with black; breast and sides buffy, streaked with black; tail feathers narrow and pointed.

This species is of a more southern distribution than the last, being rarely found in New England, but quite common in favorable localities south of Virginia.

\section{LECONTE SPARROW.}

548. Passerherbulus lecontei. 5 inches.

Hind head chestnut and gray; sides of head, throat breast and flanks a rich buff color.

Song.-A grasshopper-like squeaking.

Nest.-Of grasses in hollows of the ground on prairies; eggs greenish white thickly specked with brownish $(.65 \times .50)$.

Range.-Breeds in the Great Plains from Dakota to Manitoba, and winters southeastward to the South Atlantic and Gulf States. 


\section{SHARP-TAILED SPARROW.}

549. Passertherbulus caudacutus. $5 \frac{3 / 4}{4}$ inches.

Back of head greenish; sides of head, breast and flanks buff with black streaks; tail feathers sharp.

Salt marshes along the seacoast or along streams emptying into the ocean are the dwelling places of these finches. They creep about like mice in the salt grass, now running across an open space, now threading their way through the upright stalks.

Song.-A rather weak, squeaky trill.

Nest.-Of seaweed and marsh grass, attached to the grass stalks several inches above ground and often covered by a mass of dry seaweed. Eggs greenish white specked with brown $(.78 \times .56)$.

Range.-Atlantic coast of the U.S.

\section{NELSON SPARROW.}

549a. Passerherbulus nelsoni. 51/2 inches.

Similar to the last but brighter colored and not streaked below. In the Mississippi Valley north to Manitoba. 549a. Acadian Sharp-tailed Sparrow (sub-virgatus), Atlantic coast, breeding from Maine to New Brunswick.

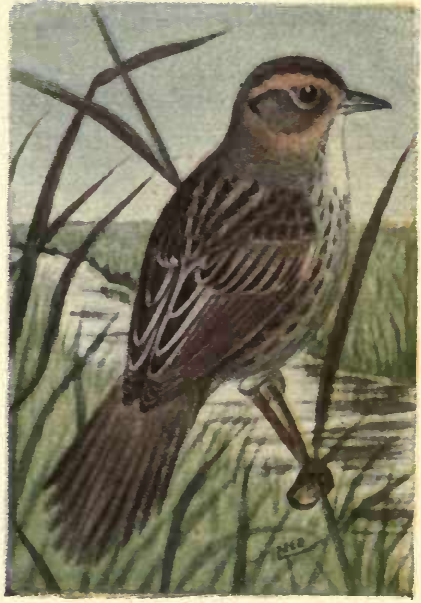




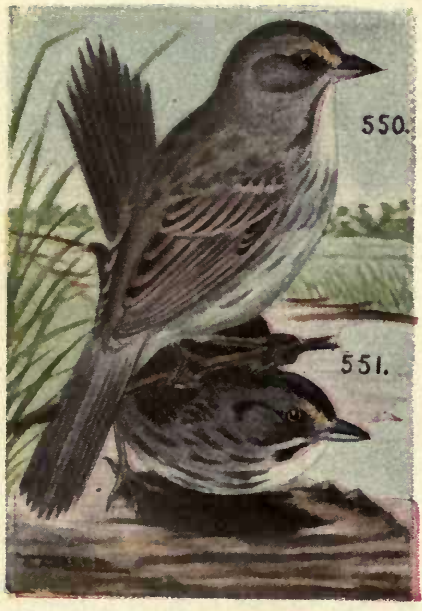

94

\section{SEASIDE SPARROW.}

550. Passerherbulus maritimus. 6 inches.

Yellow spot before the eye. General plumage above grayish green with no black markings. All the habits of the Seaside Sparrows are precisely like those of the Sharp-tailed Sparrows. The nests and eggs are indistinguishable and are often found in the same marshes.

Sub-species.-550a. Scott Seaside Sparrow (peninsulæ), slightly smaller and with the back marked with black and brownish green; South Atlantic coast. 550b. Texas Seaside Sparrow (sennetti), greener above than No. 550; coast of Texas. 550c. Fisher Seaside Sparrow (fisheri), darker above than scotti and with the breast and sides heavily washed with rusty and streaked with black; coast of Louisiana. 550d. Macgillivray Seaside Sparrow (macgillivrayii), coast of South Carolina.

\section{DUSKY SEASIDE SPARROW.}

551. Passerherbulus nigrescens. 6 inches.

Darkest of the Seaside Sparrows. Found only in marshes at head of Indian River, Florida. 


\section{IARK SPARROW.}

552. Chondestes grammacus. $61 / 4$ inches.

These handsome sparrows are very abundant in the Mississippi Valley; their favorite resorts are fields, pastures and prairie lands, or along dusty roadsides. Their song is one of the sweetest of any of the Sparrows, and is freely given throughout the summer.

Song.-A hurried gush of silvery tremulous notes.

Nest.-Sometimes in bushes but usually on the ground; of grasses arranged in a hollow to form a little cup, and usually concealed under a tuft of grass or bunch of clover. The birds usually run some distance from the nest before flying, so that they are quite hard to find. They lay three to five eggs, white, speckea and scrawled sparingly with blackish $(.80 \times \mathrm{x} .60$.$) ,$ wholly different from those of any other Sparrow.

Range.-Mississippi Valley, breeding from Texas to Manitoba; winters in southern U. S. and Mexico.

Sub-species.-552a. Western Lark Sparrow (strigatus) is slightly paler and less heavily marked; found from the Plains to the Pacific.

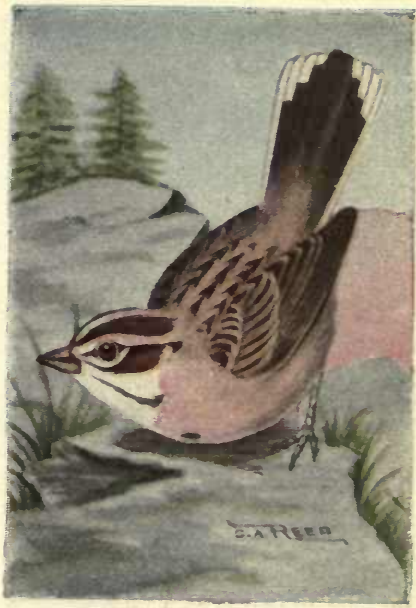




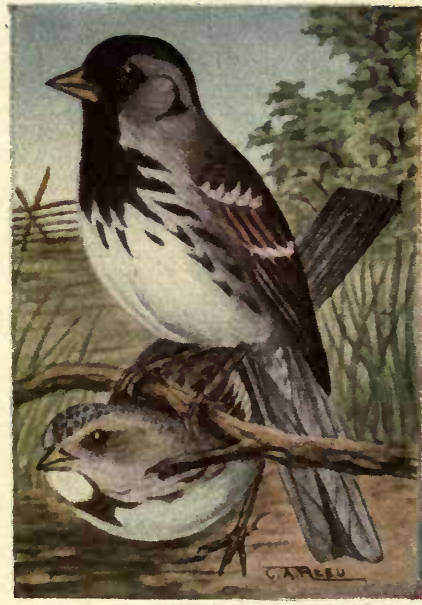

\section{HARRIS SPARROW.}

553. Zonotrichia querula. $7 \frac{1}{2}$ inches.

Adults in summer with the crown, face and throat black; in winter with the black areas mottled with gray.

This species is one of the largest of the Sparrows. It is found abundantly on the prairies during migrations, but about nesting time they all seem to disappear and no one has, as yet, been able to locate their exact breeding range. It is supposed to be among some of the foothills of North Dakota and northward through Manitoba and Saskatohewan, as they have been found during the summer in all these localities. Nests supposed to belong to this species have been found, but they lack positive identification.

Song.-A series of musical, piping whistles.

Nest.-Supposed to be of grass and bark, a few inches above the ground in weed stalks or small shrubs; eggs whitish, thickly spotted with brown $(.95 \times .65)$.

Range.-Interior U. S. from Texas (in winter) north through the Plains and Mississippi to Manitoba. 


\section{WRITE-CROWNED SPARROW.}

554. Zonotrichia leucophrys. 7 inches.

Adults with a white crown bordered by black, the black covering the lores or space before the eye (the sub-species found west of the Rockies have the lores white).

We know these birds in the U. S., except in mountain ranges or in the extreme northern parts, only as migrants, they then being found in brushy woodlots or along roadsides. In the north they are found in deeply wooded ravines and on side hills. While with us they rarely if ever sing, but in their summer home they have a clear tinkling song like that of the Whitethroated Sparrow, with which we see them associated here.

Song.-A clear, sweet, piping "see-dee-dee-dee-de-e;" call note a sharp chip.

Nest.-Usually on the ground under patches of brush or bushes. The four or five eggs are whitish profusely spotted with brown $(.90 \times .63)$.

Range.-N. A., breeding from northern U. S. northward and in high ranges south to Mexico,

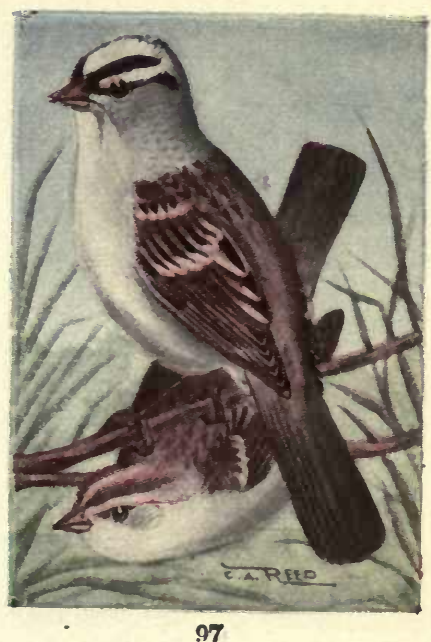

97 


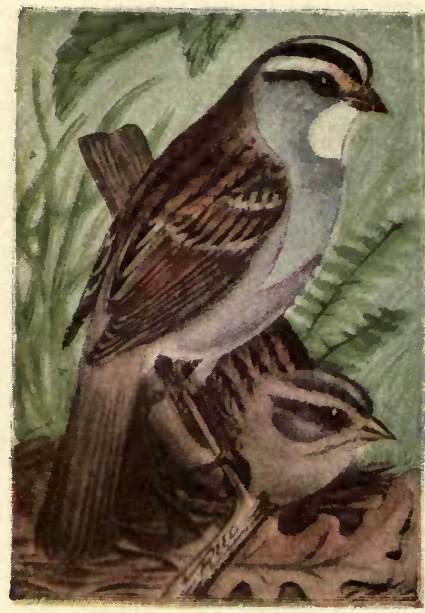

98

\section{WHITE-THROATED SPARROW.}

558. Zonotrichia albicollis. $6 \%$ inches.

In thick underbrush, we hear these birds scratching about among the leaves; occasionally one of them will hop up on a twig and give his clear peabody song, or, hearing or seeing you, give a sharp chirp and dash out of sight again. They are birds of the ground, always busy and always happy. I think that without any exception, they are the handsomest of our Sparrows, their colors are so rich and harmonize and blend together se well.

Song.-A high-pitched, very clear and sweet whistle, "pea-bo-dy-bird." Call and note of alarm, a metallic chirp.

Nest.-Usually on the ground on the borders of woods or in swamps; of grass and leaves, similar to, but larger, than that of the Song Sparrow. Four or five eggs, pale greenish blue, thickly spotted with brown (.85 x .63).

Range. $-\mathrm{N}$. A. east of the Rockies, breeding from northern U. S. to Labrador and Hudson Bay; winters is the southern half of $U$. S. 
TREE SPARROW.

559. Spizella monticola. $61 / 4$ inches.

A blackish-brown spot in middle of breast; crown reddish brown with no black about the head; back and wings with considerable brown.

These Sparrows are summer residents of the Arctic region, passing the winter in the northern balf of the U. S. They bear considerable resemblance to our common Chipping Sparrow, but are larger and have characteristic markings as noted above. They appear in the U. S. in October and many of them pass the winter in the fields and gardens in our northern states.

Note.-A musical chirp; song, strong, sweet and musical and ending in a low warble.

Nest.-Usually on the ground, but sometimes at low elevations in bushes. Eggs pale greenish blue with brown specks over the whole surface, thus being very different from those of the Chipping Sparrow $(.80 \times .60)$.

Range.-N. A. east of the Plains, breeding in Labrador and about Hudson Bay; winters in northern half of the U. S. A sub-species, 559a. Western Tree Sparrow (ochracea) is paler; it is found from the Plains to the Pacific, breeding in the north.

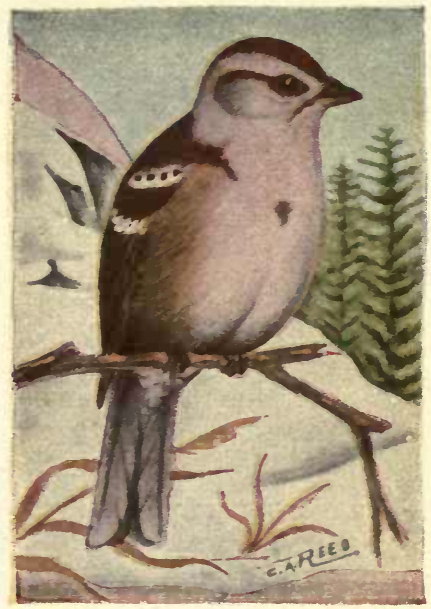




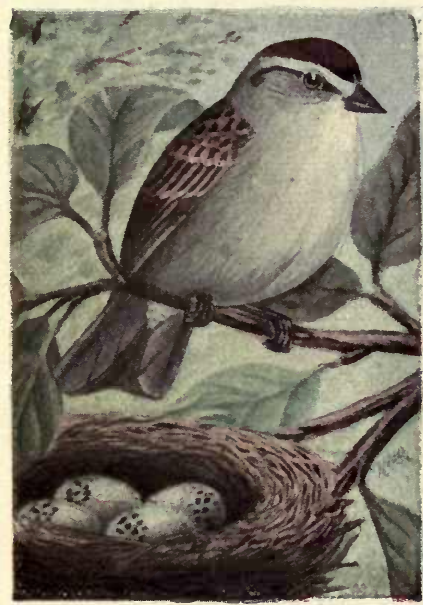

100
CHIPPING SPARROW.

560. Spizella passerina. $5 \frac{1}{4}$ inches.

Crown chestnut; forehead black; line through the eye black.

One of the commonest and most useful of our Sparrows, frequenting orchards, yards and bushy pastures. They are not at all timid and frequently nest in vines, covering porches or the side of the house, provided that English Sparrows are not too plenty. They eat great quantities of insects and worms, and some seeds, feeding their young wholly upon the former.

Song.-A very rapidly chanted chip, chip, chip, chip, continued for several seconds; call, a sharp chip.

Nest.-A small cup-shaped structure of rootlets, lined with horsehair; placed in bushes, trees or vines; eggs three to five, bluish green, specked, chiefly around the large end, with blackish brown $(.65 \times .50)$.

Range.-N. A. east of the Plains, breeding from the Gulf of Mexico north to Newfoundland and Hudson Bay; winters in the Gulf States. A sub-species is found west of the Rockies. 


\section{CLAY-COLORED SPARROW.}

561. Spizella pallida. $51 / 2$ inches.

No reddish brown in the plumage; crown largely black, with a whitish stripe in centre. The habits of these birds are the same as those of the Chippy; they are abundant on the Plains north to Saskatchewan and breed south to the northern portion of the United States. They spend the winter in Mexico. Their nests and eggs cannot be distinguished from those of the preceding, except, perhaps, by the fact that the nest has more grass than hair.

\section{BREWER SPARROW.}

562. Spizella breweri. 51/2 inches.

Like the lest species, the general tone of plumage of this is gray. It differs, though, in having the crown finely streaked with blackish. It is a more western species than the last and is rarely found east of the Rockies. It ranges from British Columbia southward into Mexico.

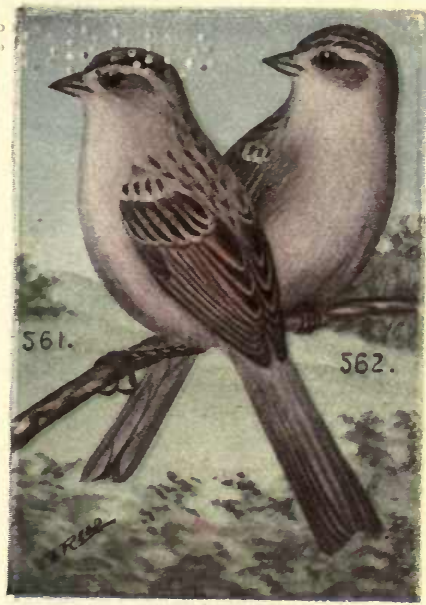




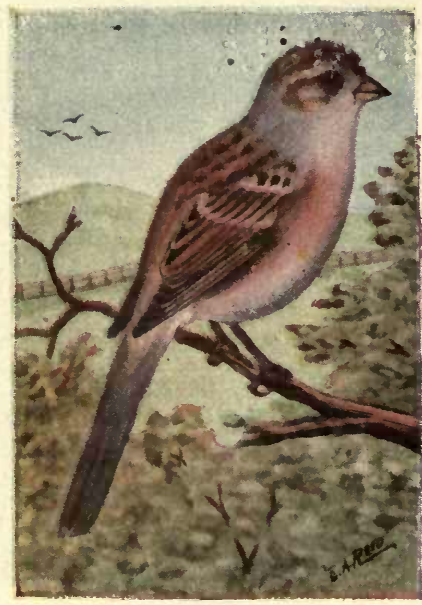

102

\section{FIELD SPARROW.}

583. Spizella pusilla. $51 / 2$ inches.

Bill pinkish-brown; crown and ear covert brown with no black markings; back reddish brown and breast and sides washed with brown.

You will find these birds in dry pastures, stubble fields and side hills. The hotter and dryer a place is, the better they seem to like it. 'They are often the only birds that will be found nesting on tracts of land recently burned over, upon which the sun beats down with stifling heat.

Song.-A series of shrill piping whistles on an ascending scale and terminating in a little trill, "sweesee-see-se-e-e."

Nest.-A frail structure of grasses and weeds, lined with finer grasses; placed either on the ground or in bushes, briars or weed patches; four or five whitish eggs marked with reddish brown $(.68 \times .50)$.

Range.-Breeds from the Gulf States north to southern Canada; winters in southern United States.

Sub-species.-563a. Western Field Sparrow (arenacea), a paler race found on the Great Plains. 


\section{WHITE-WINGED JUNCO.}

566.' Junco aikeni. $61 / 2$ inches.

Slightly larger than the common eastern Junco, and with two white bars on the wing and more white on the tail.

This species cannot be regarded as common anywhere, even locally, and in most sections of its range it is rare. There are no peculiarities in its habits and I believe that its nests and eggs have not, as yet, been discovered.

Range.-Breeds in Wyoming and the Dakotas and winters in Colorado and eastward to Kansas.

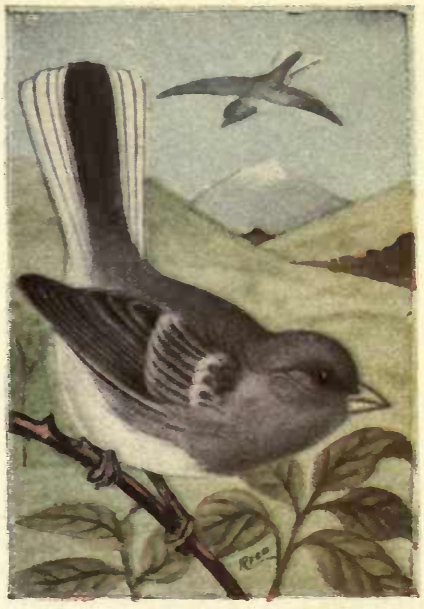




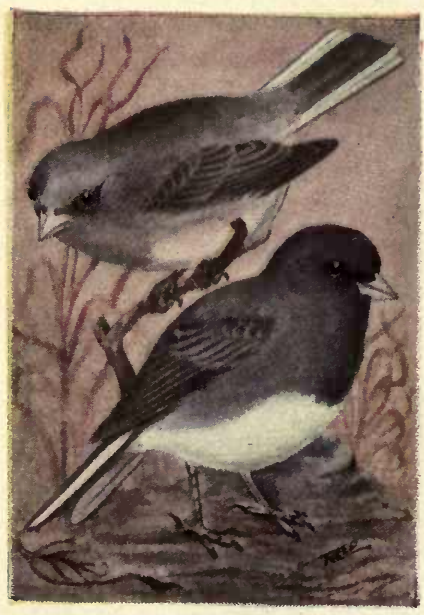

I04
SLATE-COLORED JUNCO.

567. Junco hyemalis. $61 / 4$ inches.

These are one of our most common winter birds, easily recognized, while perching or on the ground, by the white or pinkish bill, and when flying by the white outer tail feathers and the gray and white plumage. They are very common about houses as well as on the edges of woods and in pine groves, being very tame and coming into the dooryard to feed upon crumbs or chaff which is often thrown out for them.

Song.-A sweet simple trill, which has a beautiful effect when given by a whole flock in unison.

Nest.-Of grasses, on the ground, usually beside a stone, in a bunch of weeds or under a small shrub, where it is well concealed. The three or four eggs are whitish, sprinkled with reddish brown $(.75 \times .55)$.

Range.-Eastern N. A., breeding from the northern parts of the northern tier of states northward; winters south to the Gulf.

Sub-species. - 567e. Carolina Junco (carolinensis), found in the Alleghanies from Virginia to Georgia; there are several races found west of the Rockies. 


\section{BLACK-THROATED SPARROW.}

573. Amphispiza bilineata. 51/2 inches.

These little Sparrows are entirely unlike any other North American species. They are found in the southwestern deserts, where they are not uncommon in certain localities, being found in mesquite or chaparral brush.

Note.-An ordinary Sparrow chip; song, a rich metallic "zip-zip-zip-zee-zee-zee," the first three ascending, the second three notes descending.

Nest.-In bushes or cacti at low elevations; eggs plain bluish white $(.70 \times .50)$.

Range.-From Texas north to Kansas in summer. A paler sub-species, the Desert Sparrow (deserticola), is found westward to southern California.

\section{SAGE SPARROW.}

574.1 Amphispiza nevadensis. $61 / 4$ inches.

These birds are found in arid regions, frequenting the aage brush that is found in the Great Basin region, from western Texas to California.

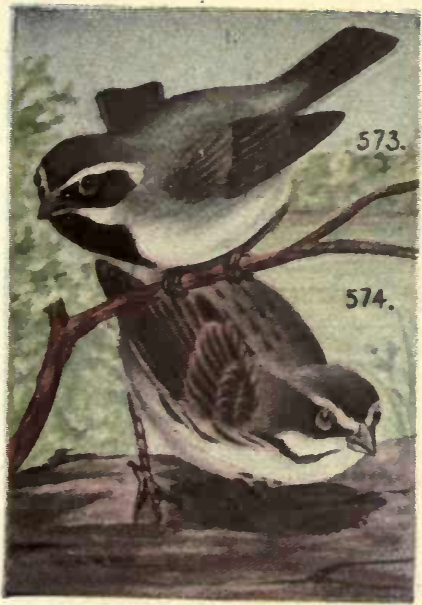




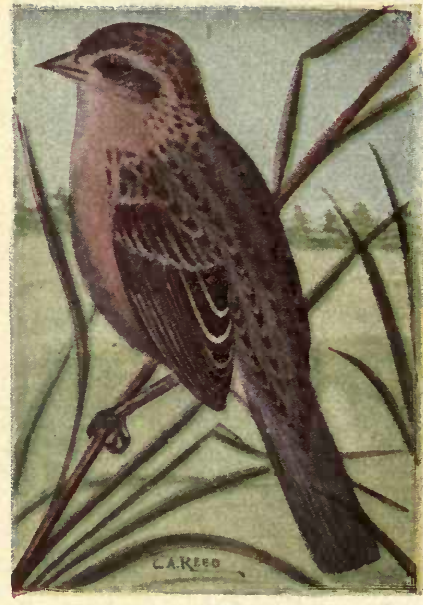

106

\section{PINE-WOODS SPARROW.}

575. Peuccea astivalis. $5 \frac{3}{4}$ inches.

Upper parts streaked with black; back chestnut and gray; under parts buffy white; tail rounded.

These dull-colored birds are abundant on some of the southern pine barrens. Their habits are similar to those of the Henslow Sparrow; they are quite shy and it is almost impossible to make one show itself above the grass, through which it runs and dodges with great swiftness. If it is surprised into taking wing it goes but a few feet, then drops out of sight again.

Note.-A metallic chip; song, similar to that of the Field Sparrow, but reversed; that is, with the trill first. Nest.--Of grasses, on the ground, under shrubs or in tufts of grass; not usually arched as those of Bachman Sparrow seem to always be; four or five pure white eggs $(.72 \times .60)$.

Range.-Georgia and Florida. 575a. Bachman Sparrow (bachmannii) is brighter above but has fewer black streaks; found in the South Atlantic and Gulf States and north to Indiana. 


\section{SONG SPARROW.}

581. Melospiza melodia. $6 \frac{1}{4}$ inches.

This is probably the best known, most abundant and most widely distributed (in its numerous sub-species) of all our birds. They are quite hardy and many of them winter in the northern states, but the majority go farther south, returning to their summer homes about the first of March. They may be found anywhere where there are bushes, vines or hedges, and very often about houses, even in large cities.

Song.-Very pleasing and musical, strongly resembling brilliant measures from that of the Canary.

Nest.-Of grass, either on the ground or in bushes; three to five bluish-white eggs, profusely spotted with brown $(.80 \times .58)$.

Range.-Eastern N. A., breeding from Virginia and Missouri north to southern Canada. Winters from Massachusetts and Ohio southward. Many local races are found west of the Rockies, but only one east of there. 581j. Dakota Song Sparrow (juddi) is found in the vicinity of Turtle Mountains, North Dakota; it is said to be lighter above and brighter below.

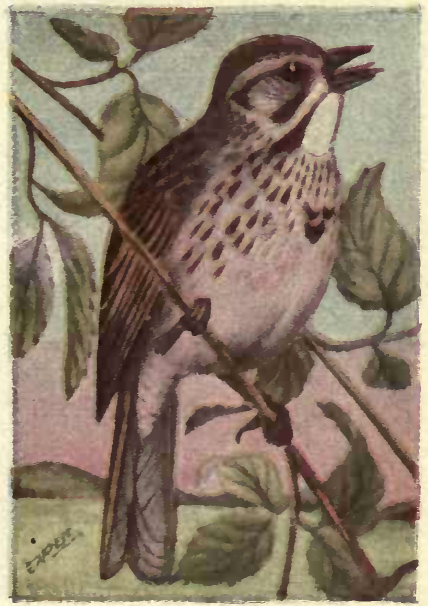




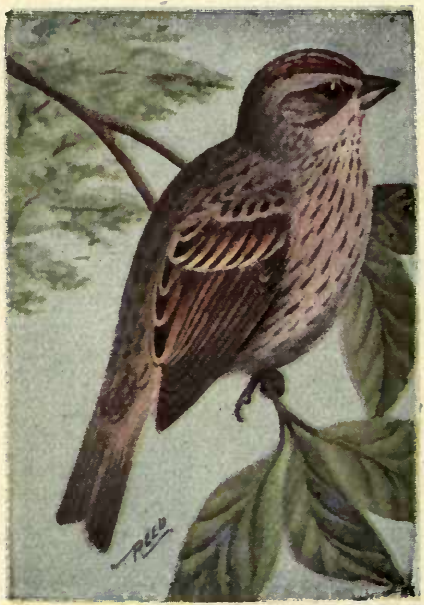

\section{IINCOLN SPARROW.}

583. Melospiza lincolnii. 5\% inches.

Upper parts extensively brown and black; breast and sides bright buff with fine black streaks.

These flinches are quite abundant in the West, especially during migrations, but are rather uncommon in the eastern states. Their habits are similar in some respects to both those of the Song Sparrow and of the Grasshopper Sparrow. They are very lively at all times and in the mating season quite pugnacious. They sit for minutes at a time upon the top of a busn pouring forth their melody, and they have one of the most brilliant songs of any of the family.

Song.-Loud, clear and gurgling, after the style of the house Wren; call, a metallic chirp.

Nest.-Of grass, on the ground, in tufts of grass or under small shrubs; eggs pale greenish white, heavily marked with chestnut $(.80 \times .58)$.

Range.-N. A., breeding from northern U. S. to Labrador and Alaska; winters in southern half of U. S. 


\section{SWAMP SPARROW.}

584. Melospiza georgiana. 5\% inches.

Forehead black; crown chestnut with a gray median stripe; whole upper parts very dark; under parts grayish with brown sides.

A very quiet and unobtrusive species that dwells, as its name implies, chiefly in swamps. They creep about under the rank weeds and underbrush like so many mice; they are especially fond of the soft mires where walking is so difficult for human beings; they patter around on the soft mud with evident enjoyment, occasionally walking across an open space of water on what floating debris they may find available.

Song.-A feeble chant; call, a sharp metallic cheep. Nest.-Of grasses, on the ground in damp places; four or five eggs, having a pale greenish-blue color heavily blotched and clouded with shades of brown $(.80 \times .55)$.

Range.-N. A. east of the Plains, breeding from New Jersey and Missouri north to Labrador and Hudson Bay; winters in southern half of the U. S.

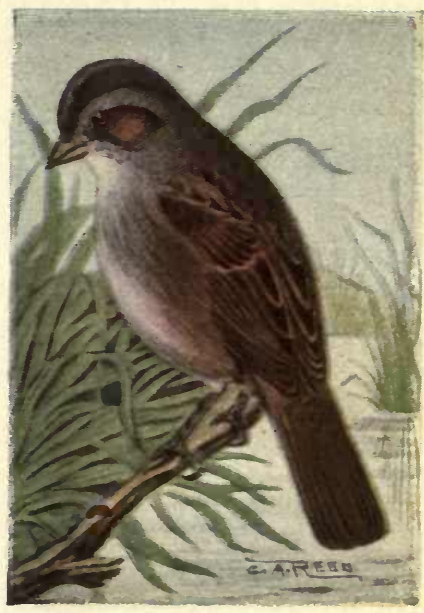

109 


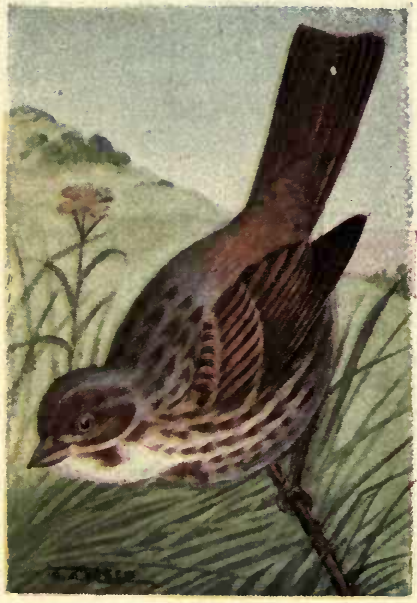

110

\section{FOX SPARROW.}

585. Passerella iliaca. $71 / 4$ inches.

Above bright reddish brown and gray; rump and tail wholly reddish brown, and spots on the breast and sides of the same color.

In winter we find these large Sparrows in quiet - swamps and open woods, where they scratch about among the fallen leaves, after the manner of domestic fowls; they will scratch energetically for a few seconds, then pause to see what they have uncovered. They have a short but loud and joyful song, with which they greet you on clear frosty mornings, and the effect is very beautiful when a large flock of them are singing in chorus. chip.

Song.-A loud, clear and melodious carol; call, a soft

Nest.-Of grass and moss, lined with fine grass and feathers; four or five pale bluish-green eggs, spotted with reddish brown and chestnut $(.90 \times .65)$.

Range.-N. A. east of the Rockies, breeding from New Brunswick and Manitoba northward; winters in the southern states. 


\section{TOWHEE OR CHEWINK.}

587. Pipilo erythrophthalmus. 8 inches.

A bird of swamps, brushy pastures and open woodlands. They are ground birds and usually found scratching among the leaves; the male, with his black, white and brown clothes, makes a conspicuous object, while the female, with her brown and white dress, harmonizes with the leaves so that it is difficult to see her. While his mate is sitting on her nest, the male will frequently sit in a tree top and persistently sing for many minutes at a time.

Song.-Loud and clear, "tow-hee-e-e" or "see-towhee-e-e," with the last notes tremulous; call, a sharp "cherink."

Nest.-Usually on the ground, but rarely in bushes; of strips of bark, grass and leaves; eggs white with reddish-brown dots over the whole surface $(.90 \times .70)$.

Range.-Eastern N. A., breeding from the Gulf States to southern Canada; winters in southern U. S.

Sub-species.-587a. White-eyed Towhee (alleni) has white eyes instead of red and less white on the tail; found on the South Atlantic coast.

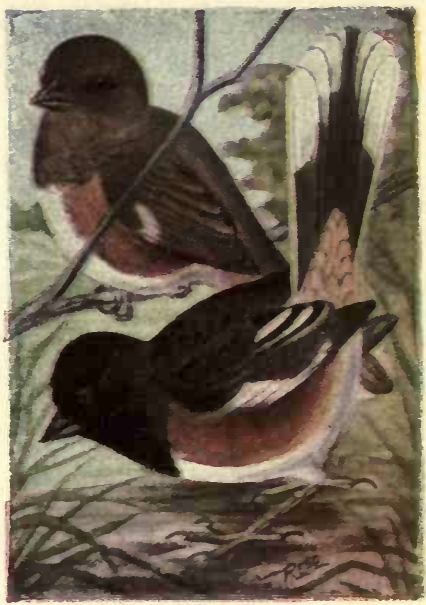

111 


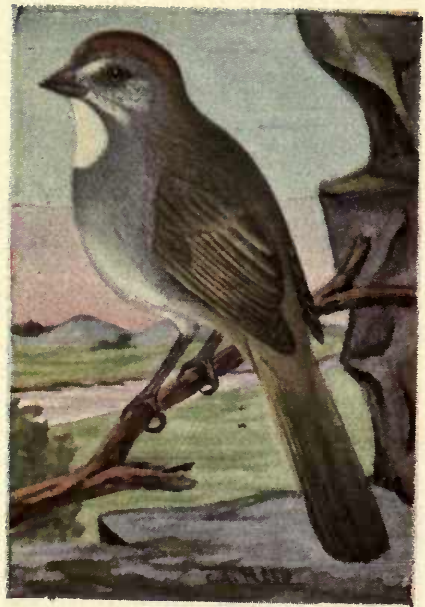

112

\section{GREEN-TAILED TOWHEE.}

592.1. Oreospiza chlorura. 7 inches.

These are characteristic birds of the Western moun. tains. They are typical brush birds, satisfied in living a life of security in their own way, and rarely appear above the surface of the thick shrubbery except to mount to a conspicuous twig, pour forth their sweet melodies and then retreat again.

Notes.-A loud chip; a soft, mewing note; song, finch-like, musical but rather simple

Nest.-Either on the ground or in bushes near the ground. Made of grasses the same as that of any of the sparrows. Eggs pale bluish gray, thickly speckled with reddish brown. The nests are built in very thickly tangled underbrush and are difficult to locate.

Range.-Western United States, from the eastern base of the Rockies west to the eastern slope of the Sierra Nevadas. 
CARDINAT.

593. Cardinalis cardinalis. 9 inches.

Noble in carriage, beautiful of plumage, amiable in disposition and excellent singers are some of the qualifications of these large-billed birds. They are southern birds, rarely seen in northern U. S. unless in cages, for large numbers of them are trapped for this purpose, a practice that is being stopped as rapidly as possible by enforcing the laws which protect them. They are hardy birds, often passing the winter in the northern parts of their range when the ground is covered with snow. They frequent gardens, plantations and open woods, where they glean their food of seeds, berries, fruit and insects. chip.

Song.-A loud, clear and lively warble; call, a low

Nest.-A frail structure of twigs, in thickets or bushes; eggs greenish blue with reddish-brown spots $(1.00 \times .73)$.

Range.-Resident and breeding from the Gulf to New York and Iowa. 593. Florida Cardinal (flori$\underset{8}{d}$ anus) is supposed to be sligbtly smaller and brighter.

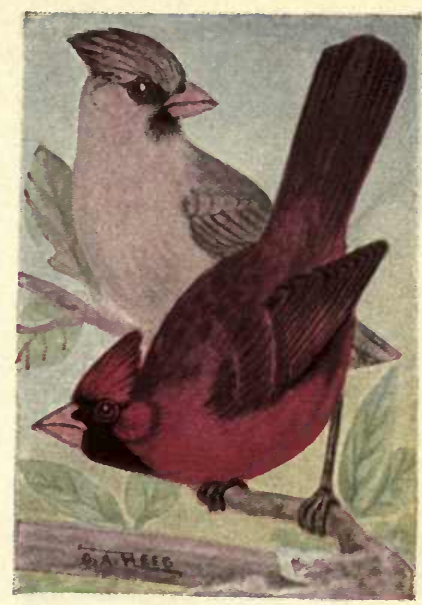

113 


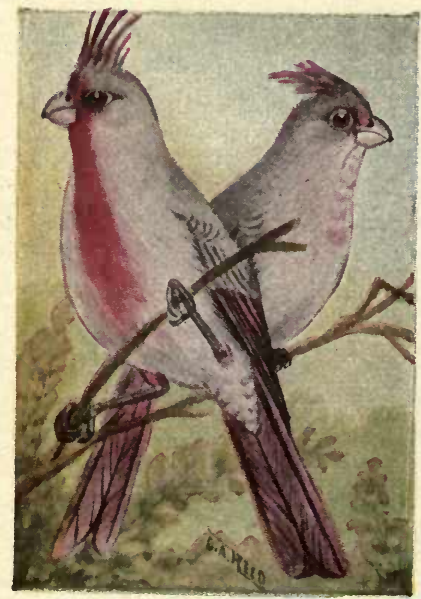

114

\section{TEXAN CARDINAL; PYRRHULOXIA.}

594a. Pyrrhuloxia sinuata texana. $8 \frac{1}{2}$ inches.

Notice that the bill of this species is very stout and short, more like that of a parrot. The crest is also composed of fewer feathers than that of the Cardinal. It is only in the highest of plumages that the red on the underparts is continuous from bill to tail; usually it is broken into patches. The female is much duller in color than the male, but always has a strong tinge of rose color. They frequent more open and exposed positions than do Cardinals and are more shy in their disposition.

Nest.-Shabby platforms of twigs and grasses placed at low elevations in thickets. The three or four eggs are whitish, specked with dark brown, most profusely at the large end $(.90 \times .70)$.

Range.-Abundant in the Lower Rio Grande Valley in southern Texas. 


\section{ROSE-BREASTED GROSBEAK.}

595. Zamelodia ludoviciana. 8 inches.

Male, black and white with rose breast and under wing coverts; female resembling a large striped Sparrow in color.

The center of abundance of these beautiful creatures is in the northern half of eastern U. S. In beauty and song he fully atones for what we northerners lose because of the southerly distribution of the Cardinal. We find them in swamps, small patches of woods, and, sometimes, in orchards. They are rather quiet birds, that is they do not move about much, but they can easily be found by their song.

Song.-A rich, full, whistling carol, almost without exception immediately preceded with a sharp chip. Call, a deep-toned chirp.

Nest.-A loose, frail cradle of twigs at low elevations in trees or thickets; eggs bluish green spotted with brown ( $1.00 \times .75)$.

Range.-U. S. east of the Rockies, breeding in the northern half and in southern Canada; winters in Central America.

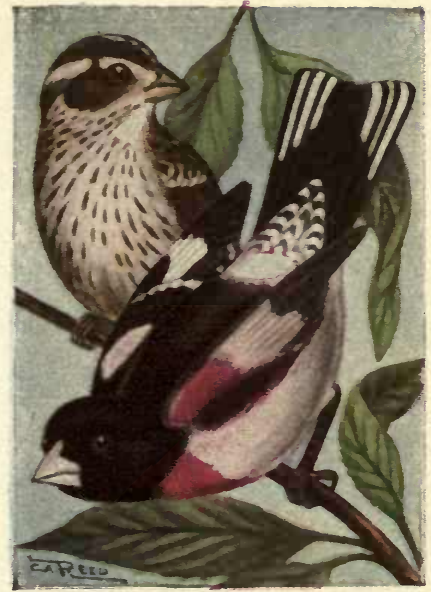

115 


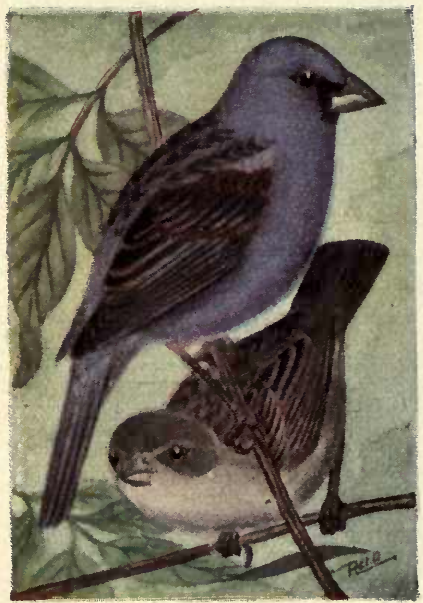

116

\section{BLUE GROSBEAK.}

597. Guiraca carulea. 7 inches.

Male, deep blue with chestnut shoulders; female, grayish brown above and grayish white below.

Open woods, small groves and roadsides are the locations in which these birds will be apt to be found. In some places they are fairly common, but nowhere abundant. Their habits are very similar to those of the Rose-breasted Grosbeak.

Song.-A rapid varied warble, similar to but louder and stronger than that of the Indigo Bunting.

Nest.-Of twigs, weeds and grasses, lined with fine rootlets; placed in thickets, bushes or low trees; four or five plain bluish-white eggs $(.85 \times .62)$.

Range.-Eastern U. S., breeding from the Gulf to Maryland and Illinois; winters south of U.S.

Sub-species.-597a. Western Blue Grosbeak (lazula). Male of a brighter shade of blue than the eastern; found from the Mississippi to the Pacific, breeding north to Kansas, Colorado and northern California. 


\section{INDIGO BUNTING.}

598. Passerina cyanea. $51 / 2$ inches.

Male, indigo blue; female, brownish but usually with a faint indication of blue on the wings or tail.

A jolly summer songster, dwelling with us from the latter part of May until September. You will meet with these Buntings along roadsides lined with scrubby trees or bushes, or in pastures or along the edges of swamps. The male usually has some favorite perch upon which he spends a large portion of his time singing; it is nearly always the top of a tall bush or tree.

Song.-A sprightly little warble with many canarylike notes. Call, a sharp chip.

Nest.-Of grasses at low elevations in shrubs or bushes; eggs four or five in number, very pale bluish white $(.75 \times .52)$.

Range.-U. S. east of the Rockies, and most abundant east of the Mississippi ; breeds north to Manitoba and New Brunswick; winters in Central America.

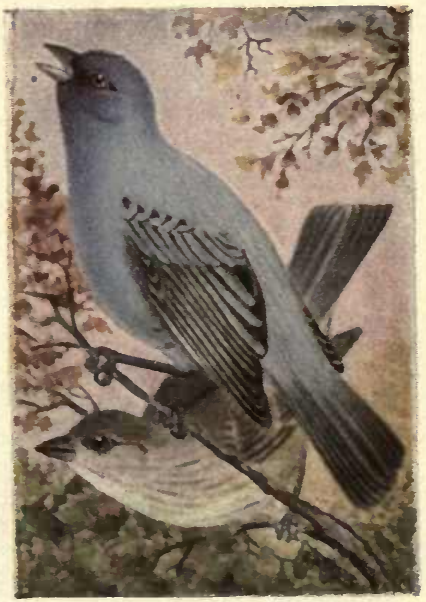

717 


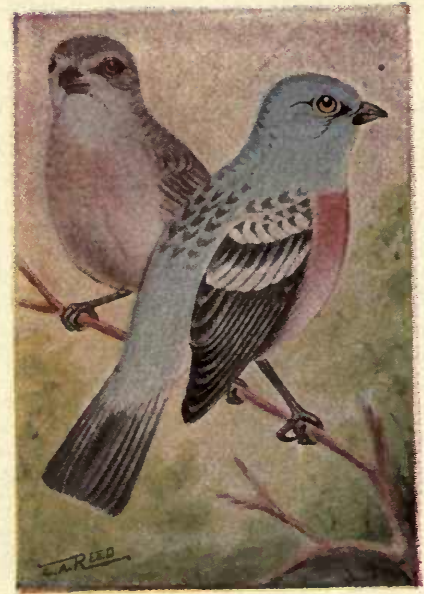

LAZULI BUNTING.

599. Passerina amœna. $5 \frac{1}{2}$ inches.

This species replaces the preceding one west of the Plains. While the plumage of the males is entirely distinctive, that of the females is often confusing. The present species has quite a conspicuous band of rusty buff across the breast and lacks any sign of stripes on the sides, such as show faintly on the last species. Its habits are just like those of the Indigo and it frequents the same kind of territory.

Nest.-Built in a bush or on the lower branches of trees, only a few feet from the ground. The eggs are very pale bluish white $(.75 \times .58)$.

Range.-Western United States from the Great Plains to the Pacific coast; north along the coast to British Columbia; south in winter to Mexico. 


\section{VARIED BUNTING.}

600. Passerina versicolor. $51 / 2$ inches.

This beautiful species is less common than any others of the genus and has a very restricted range in the United States. The plumage of the male birds varies a great deal; that shown in the accompanying illustration is from a brightly colored specimen. They will average duller than this. These birds frequent thickets or brush-studded pasture land. Their song is described as weaker than that of the Indigo Bunting, but having much of the same character.

Nest.-Built of grasses, bark and fine rootlets; a cup-shaped structure placed in forks of bushes, usually in tangled thickets. The three or four eggs cannot be distinguished from those of the last species.

Range.-The Lower Rio Grande Valley in southern Texas. A sub-species (pulchra) is also found in Lower California and southern Arizona.

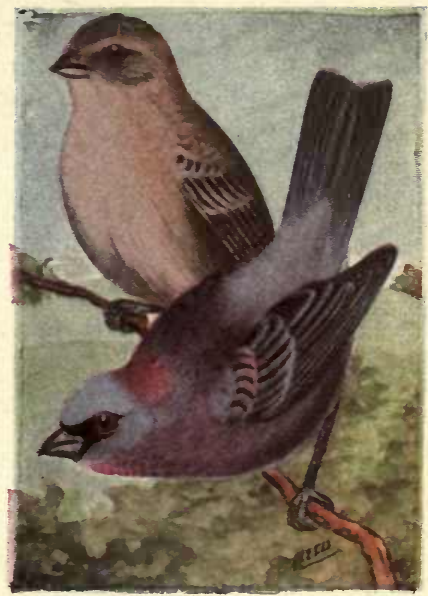

119 


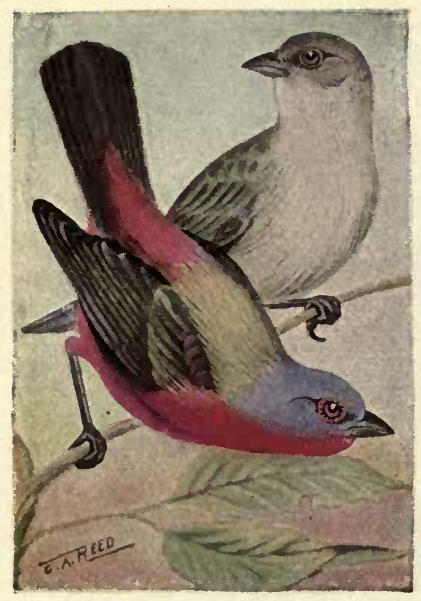

120
PAINTED BUNTING.

601. Passerina ciris. $51 / 2$ inches.

Male, vari-colored; female, greenish gray.

Without any exception, these are the most gaudily plumaged North American birds, but their colors have a harshness of contrast that renders them far less pleasing to the eye than many others of our birds. They are often caged, but in confinement soon lose the natural brilliancy of their plumage. Like the Indigo Bunting, they are found in thickets and hedges; their habits seem to be precisely like those of the last species. Song.- Similar to that of the Indigo but lacking the brilliancy of that of the latter bird.

Nest. - Of grasses, leaves, strips of bark and rootlets, compactly compressed and woven together, situated at low elevations in thickets and low bushes; eggs whitish, specked and blotched with reddish brown $(.78 \mathrm{x}$ $.58)$.

Range.-Southeastern U. S., breeding from the Gulf north to Virginia, Ohio and Kansas; winters in Central America. 


\section{MORELIET SEED-EATER.}

602. Sporophila morelleti sharpei. $4 \frac{1}{2}$ inches.

The male of this interesting little species requires at least three years in which to obtain the perfect plumage as shown in our illustration. The majority of birds seen will be in intermediate stages of plumage between that of the adult female and this one. These little fellows are usually found in thickets or patches of briars and are quite tame.

Note.-During the breeding season the male has a sprightly song similar to that of the Indigo Bunting.

Nest.-The nests are made of fine grass and placed in bushes or young trees. The eggs are bluish green spotted rather evenly with brown (.65 x .48).

Range.-Southeastern Texas and southward into Mexioo.

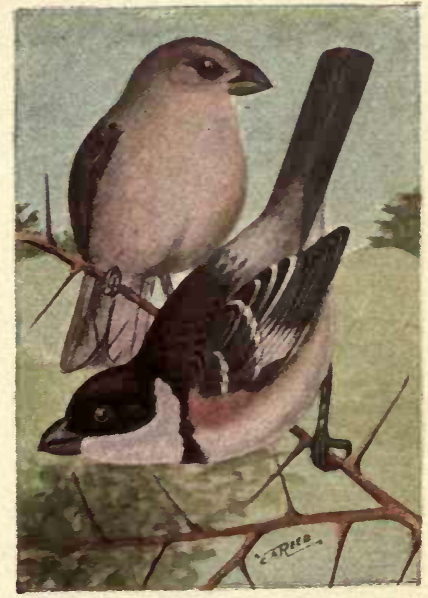

121 


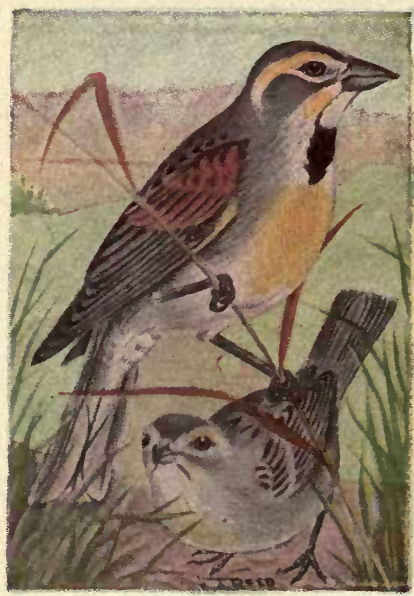

122

\section{DICKCISSEL.}

604. Spiza americana. $61 / 4$ inches.

Male beautifully blended with yellow, white and gray, and with a black throat patch and brown shoulders; female duller.

In the middle portions of the U. S. these birds, or Black-throated Buntings, as they are commonly called, are very numerous, frequenting dry, bushy fields or prairies. They are very persistent songsters, although their song is weak and has little melody. In July and August, when many birds are silent, they continue their plaintive chant even on the most sultry days.

Song.-A simple chanting "chip, chip, che-che-che."

Nest.-Either on the ground, in bushes or thistles, or in trees; of weeds, grasses, rootlets, corn husks, etc.; eggs four or five in number, plain bluish white and hardly distinguishable from those of the Bluebird; size $.80 \times .60$.

Range.-N. A. east of the Rockies, breeding from the Gulf States north to northern U. S.; rare in the Atlantic States north to Connecticut. 


\section{IARK BUNTING.}

605. Calamospiza melanocorys. 7 inches. Male, black and white; female, brown and gray. This species is often known as the White-winged Blackbird, not because it bears any resemblance to any of the Blackbirds, nor because any of the habits are the same, but simply because of its plumage. They are very gregarious and usually fly in flocks even in nesting time.

They seem to be very methodical and well trained; if one of a flock takes wing, the entire flock rises simultaneously and in a very compact body they fly until some leader chooses the next stopping place, when they as suddenly alight. They have the habit of Skylarks in mounting into the air while singing and then descending on set wings.

Song.- A very lively, sweetly modulated warble.

Nest.- On the ground, usually under a tuft of grass or small bush; four or five eggs of a bluish color $(.85$ $x .65$ ), brighter than those of the Dickcissel.

Range.-Western U. S., most abundant from Kansas to Colorado and north to Assiniboia.

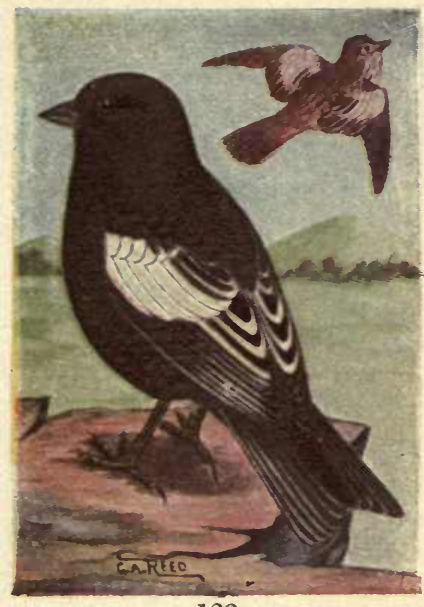

123 


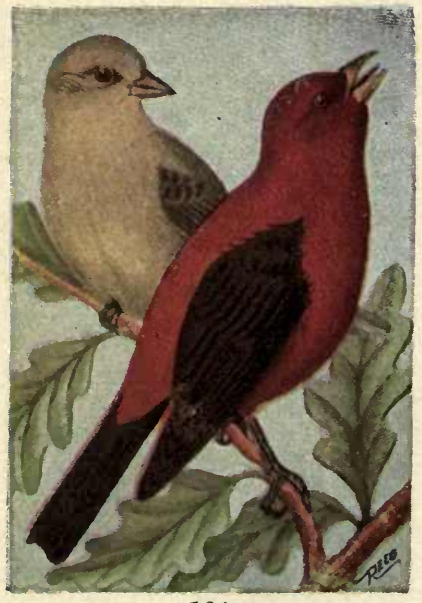

124
SCARLET TANAGER.

608. Piranga erythromelas. $71 / 2$ inches.

Male, scarlet and black; female, greenish yellow and blackish.

These beautiful birds are found in open woods, but they often come out in fields, parks, orchards and sometimes in yards when feeding; one of the prettiest sights that I ever saw was of about a dozen of these birds tripping along the furrows of a ploughed field, where they were feeding on insects. Besides berries and seeds, they live upon quantities of insects, frequently catching them on the wing in true Flycatcher style.

Song.-Resembling that of the Robin, but harsher, less varied and higher pitched. Call, a sharp chip or "chip-churr."

Nest.-Loosely made of twigs and rootlets, on lower branches of trees; eggs four, pale bluish green, spotted with brown $(.95 \times .65)$.

Range.-Breeds in the northern parts of the U. S. from the Atlantic to the Plains; winters in the tropics, whence it arrives about May 15. 


\section{SUMMER TANAGER.}

610. Piranga rubra. $71 / 2$ inches.

Male, rosy red; female, greenish yellow.

These Tanagers have a more southerly distribution than the Scarlet variety, but are found in the same kind of territory. In its localities it is rather more abundant and less retiring than is the latter bird in the north, and more often dwells in public parks. This bird is often called the Redbird and in localities where both the Scarlet Tanager and this species are found, they are frequently known by the same name, as their habits and notes are similar.

Song.-Similar to that of the Scarlet Tanager but said to be sweeter and clearer, and to more nearly resemble that of the Robin.

Nest. - On the outer horizontal limbs of trees in open woods or groves; nest of twigs and rootlets; eggs bluish green, spotted with brown $(.95 \times .65)$.

Range.-U. S. east of the Rockies, breeding from the Gulf to New Jersey and Kansas; winters in Central America. A sub-species is found west of the Rockies.

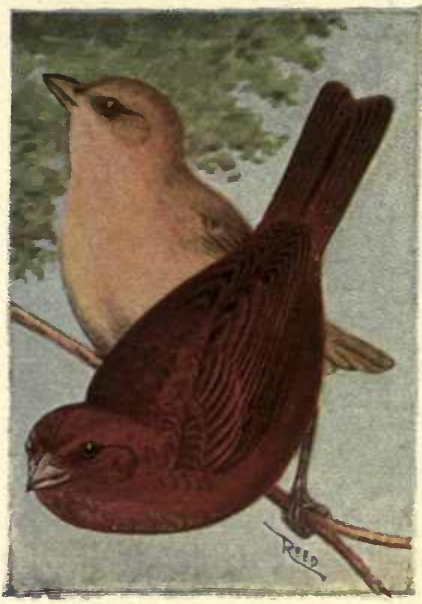

125 


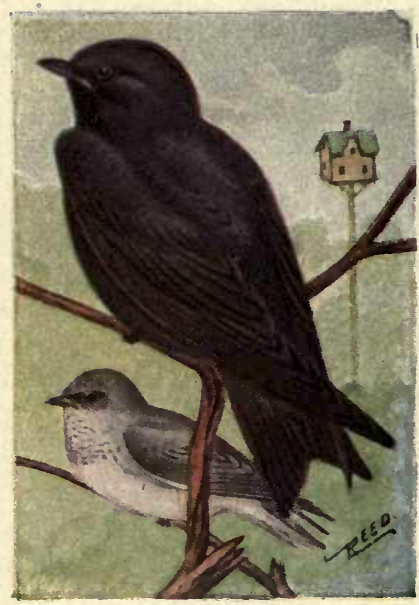

186
PURPLE MARTIN.

611. Progne subis. $73 / 4$ inches.

Male, blue black; female, dull black and grayish.

These large, jolly Swallows are commonly seen about cities and towns within their range. Originally they dwelt in hollow trees, and some do yet, but the majority have recognized the superiority of man's dwelling and now live in houses built especially for them or in cornices of houses or barns. It is no uncommon sight to see a handsome gabled structure of many rooms, perched upon a twelve-foot pole, on the lawns of many wealthy residents; others less bountifully supplied with this world's goods use plain soap boxes for the same purpose, and the Martins seem to like the one as well as the other.

Song.-A strong, varied grating warble or twitter, more forcible than melodious.

Nest.-Of straw, paper, rags, etc., in bird houses, gables or hollow trees; eggs dull white $(.98 \times .72)$.

Range.-N. A., breeding from the Gulf to New Brunswick and Saskatchewan; winters in northern South America. 


\section{CLIFF SWALLOW.}

612. Petrochelidon lunifrons. $5 \frac{1}{2}$ inches.

Adults similar in plumage but the female slightly paler. Easily distinguished from the Barn Swallow by the square tail and light buffy forehead and rump.

This is what is commonly called the Eave Swallow in the East, because of its habit of plastering its nests on the outside of barns or other buildings, up under the eaves. In the West they usually resort to cliffs where, sometimes, large sections of the face will be completely covered with the little mud flasks; often colonies of sereral thousand will build their nests together.

Song.-A continuous twitter, uttered while on the wing or at rest.

Nest.-A flask or gourd-shaped structure of mud, lined with straw and feathers, attached under the eaves to the outside of buildings or on the faces of cliffs; five to seven eggs are laid; white dotted and spotted with reddish brown $(.80 \times .55)$.

Range.-N. A., breeding from the Gulf to Greenland and Alaska; winters in the Tropics.

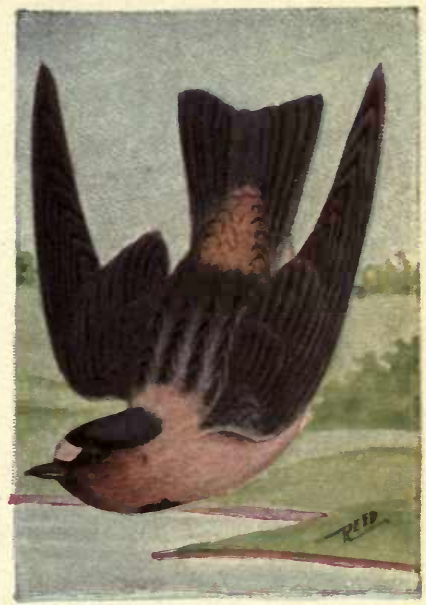




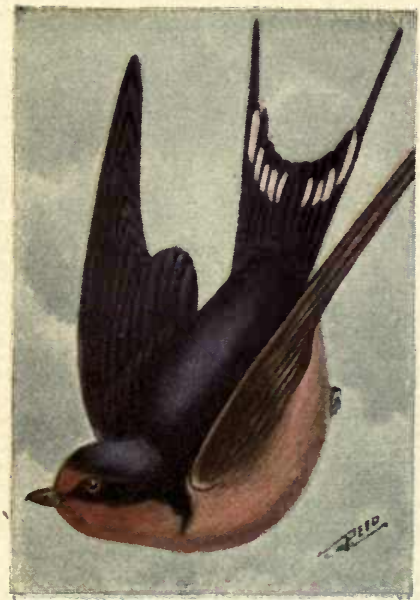

128

\section{BARN SWALLOW.}

613. Hirundo erythrogastra. 71/2 inches.

Female duller plumaged and with a less deeply forked tail than the male. Forehead and throat chestnut and entire under parts buffy; tail deeply forked and with a white spot on the inner web of each feather except the central pair.

This is the most graceful and beautiful of all our swallows, and is the most common about farm houses, the inside beams and rafters of which they appropriate for their own use. They delight in skimming over the rolling meadows or the surface of ponds, now rising with the wind, now swooping downward with the speed of an arrow.

Song.-A continuous, rapid twitter.

Nest.-A bowl-shaped structure made up of pellets of mud cemented together with the birds' saliva, and lined with feathers; attached to rafters in barns, the opening being at the top and not at the side as in the last; eggs exactly like those of the last.

Range:-N. A., breeding north to the limit of trces; winters in northern South America. 
TREE SWALLOW.

614. Iridoprocne bicolor. 6 inches.

Male, steely blue or greenish above; female, duller and often plain gray above, but both sexes always entirely white below.

These Swallows are also abundant about farmyards; except when they are skimming over ponds, they are almost always scouring the air above buildings or fields, at higher elevations than the Barn Swallows. When weary they roost on dead twigs or telephone wires, hundreds often being seen in rows on the latter. Like the Martins, these birds frequently nest in bird boxes, but usually not more than one or two pairs in a single house. lows.

Notes.-A twittering like that of the other Swal-

Nest.-Of grass, lined with feathers, in hollow trees on the border of water or in orchards, or in bird boxes erected for their use; eggs white $(.75 \times .52)$.

Range.-Breeds in the northern half of the U. S. and northward to Labrador and Alaska; winters in southern U. S. and southward.

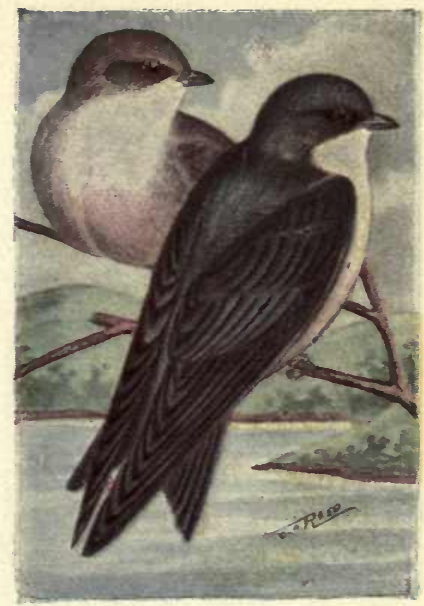

129 


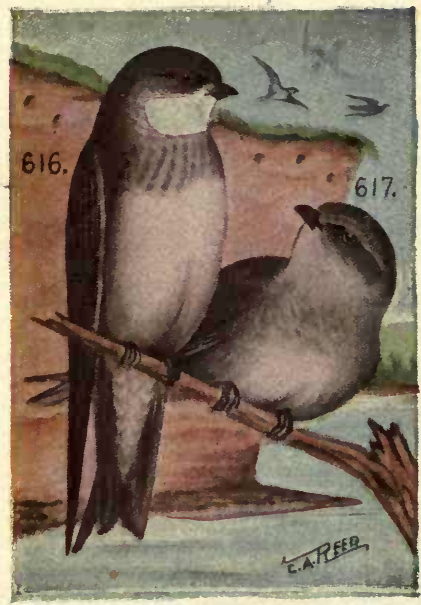

130

\section{BANK SWALIOW.}

616. Riparia riparia. $51 / 4$ inches.

These are the smallest of our Swallows; this species can be distinguished, even at a distance, by the conspicuous band across the breast, showing in bold relief against the lighter throat. They are found throughout North America, breeding from the middle of the U. $\mathrm{s}$. north to the Arctic regions.

They nest in colonies in holes in banks, laying the four to seven white eggs on a grass nest in an enlarged chamber at the end of the tunnel.

\section{ROUGH-WINGED SWALLOW.}

617. Stelgidopteryx serripennis. 51/2 inches.

In this species the throat is gray as well as the breast. The outer vane of the outer primary is stiff and bristly, thus giving the species its name. These birds breed from the Gulf north to Massachusetts and Washington, in banks or in crevices of stone bridges. The eggs cannot with certainty be distinguished from those of the Bank Swallow. They measure .75 $\times$.52. 


\section{BOHEMIAN WAXWING.}

618. Bombycilla garrula. 8 inches.

Larger and grayer than our common Cedar Waxwing and with yellow and white on the wing; it is a northern species and is only casually found in eastern U. S. They nest within the Arctic Circle and only a few of their nests have ever been found. In winter they are found in flocks, roving restlessly about the country, often appearing where least expected and utterly deserting other places where they are usually found.

Nest. - Of small twigs and moss, lined with feathers, usually placed at low elevations in spruce or coniferous trees; eggs dull bluish white specked sparingly with black $(1.00 \times .70)$, similar to those of the Cedar Waxwing but larger.

Range.- Northern parts of the northern hemisphere, breeding within the Arctic Circle and wintering casually south to Massachusetts, Pennsylvania, Kansas and California.

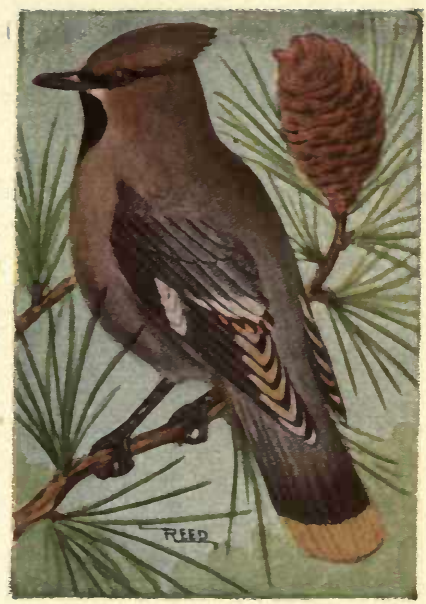

131 


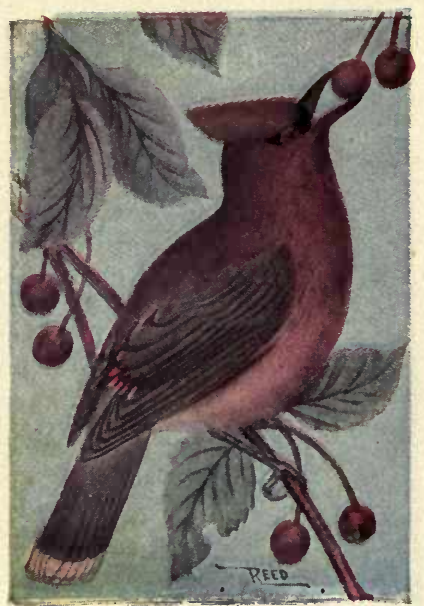

182

\section{CEDAR WAXWING.}

619. Bombycilla cedrorum. 7 inches.

Plumage very soft colored with a general brownish tone, shading to gray on the rump. The Waxwings are named from the curious wax-like appendages attached to the tips of the secondaries, and rarely to the tail feathers. They are very sociable and usually feed in flocks. They live chiefly upon fruit and are especially fond of cherries, for which reason they are very often known as Cherry-birds. They are very tame and allow anyone to almost touch them while they are feeding or sitting upon their nests.

Note.-An insignificant lisping hiss.

Nest.-A substantial structure of twigs, mosses, twine, etc., lined, with fine grasses; placed in cedar trees or, when near habitations, usually in orchard trees; the four or five eggs are dull bluish white, specked with black $(.85 \times .60)$.

Range.-N. A., breeding from-Virginia, Missouri and northern California north to Labrador and southern Alaska; winters throughout the United States. 


\section{NORTHERN SHRIKE.}

621. Lanius borealis. 10 inches.

This shrike is larger than any of the species found in summer in the United States and has the breast quite distinctly barred.

Shrikes are cruel, rapacious and carnivorous birds, feeding upon insects, grasshoppers, lizards and small birds. As they have passerine feet, the same as all our small birds, they are unable to hold their prey between the feet while tearing it to pieces, so they impale it upon thorns or the barbs of a wire fence, so they may tear it to shreds with their hooked bill.

Song.-Loud snatches consisting of various whistles and imitations suggesting that of a Catbird.

Nest.-They breed chiefly north of the U. S., placing their rude, bulky structures of twigs and weeds in thorny trees or hedges; their four to six eggs are grayish white with spots of light brown and darker gray $(1.08 \times .80)$.

Range.-N. A., breeding chiefly in the northern parts of Canada; winters south to Pennsylvania, Kansas and California.

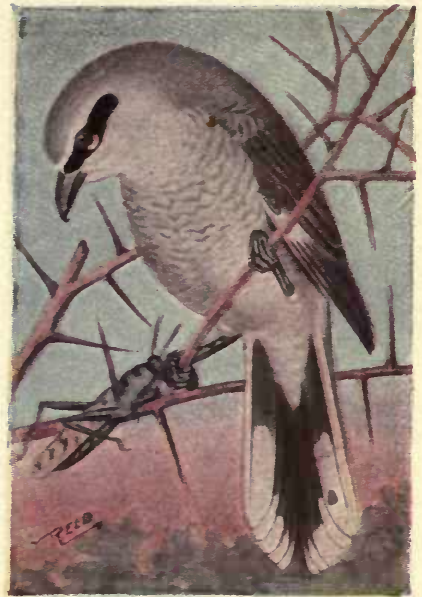




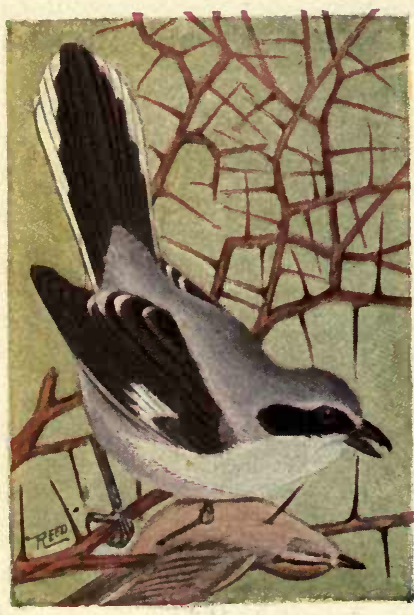

134
LOGGERHEAD SHRIKE.

622. Lanius ludovicianus. 9 inches.

Pure white below and with the markings above, intense black instead of the brownish or grayish black of the last species. Although smaller, these Shrikes have the same destructive habits of the northern species. All the Shrikes do considerable good to mankind, for they eat quantities of grasshoppers and mice, and probably resort to their diet of small birds when other food is unusually scarce. It cannot be denied that they are cruel, for they often kill more than they can eat and leave it impaled on thorns to decay.

Song.-Of harsh, discordant whistles.

Nest.-In scrubby hedges and thickets; of twigs, weeds, leaves, etc.; eggs four to seven in number, grayish white, spotted with shades of brown and gray.

Range.-Eastern U. S., breeding from the Gulf tc southern New England and Manitoba; winters in southern states.

Sub-species.-622a. White-rumped Shrike (excubitorides), paler and with a white rump; found from the Plains to the Pacific in the U. S. 


\section{RED-EYED VIREO.}

624. Vireosylva olivacea. 6 inches.

Crown slaty gray with a black border; white stripe above eye; eye reddish brown.

Throughout the United States this is one of the most abundant of the family. All through the spring and summer months their warble is heard from woodland and roadside, often becoming so monotonous as to be irritating. Oftentimes during the spring migrations of Warblers, Vireos are so numerous and singing so lustily that it is impossible to hear or distinguish the songs of any of the smaller birds.

Song.-Delivered in parts with intermission of a few seconds between, from morning until night; a short varied warble; call, a petulant mew.

Nest.-A basket woven of strips of bark and fibres, and often with pieces of newspaper worked in, lined with fine grass; eggs white with a few blackish-brown specks on the large end (.85 x .55).

Range.-U. S. east of the Rockies, breeding from the Gulf to Labrador and Manitoba; winters in Central America.

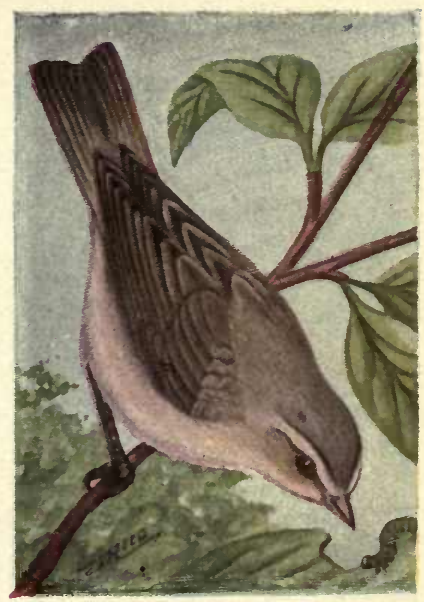




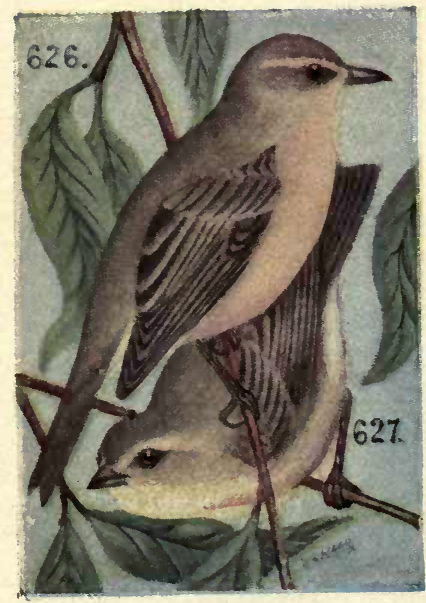

\section{PHILADELPHIA VIREO.}

626. Vireosylva philadelphica. 5 inches.

This is one of the least common of the eastern Vireos, although it is more common than most people know; its song is not distinctive and it keeps high up in trees, so it is not usually noticed. Their nests are swung from branches at high altitudes and are seldom found.

\section{WARBLING VIREO.}

627. Vireosylva gilva. 5 inches.

Above olive-green; crown grayer but with no black border. These are among the most common of the Vireos and may be found even in the hearts of large cities, swinging their pretty little nests high up in shade trees. Their song is after the style of that of the Purple Finch, very different from that of the Red-eye. The eggs are white with a few brown specks on the large end. These birds breed throughout the U. S. and southern Canada. 


\section{YELLOW-THROATED VIREO.}

628. Lanivireo flavifrons. $5 \frac{3}{4}$ inches.

Upper parts greenish; throat, breast and line over eye yellow; two prominent whitish wing bars.

A handsome Vireo found in localities such as are frequented by the Red-eyed species. Nowhere do they appear to be as abundant as that species, however; they are more abundant than many suppose, but the difficulty of clearly seeing the yellow breast when they are feeding in the tree tops, combined with the similarity of their songs, usually caused them to be passed by without inspection.

Song.-Similar to that of the Red-eye, but louder and more nasal, less varied and not uttered as often.

Nest.-A pensile structure of strips of bark, grasses, etc., with the outside often ornamented with lichens; three to five eggs with a creamy or rosy-white tint, specked, more profusely than those of the Red-eye, with reddish brown $(.82 \times .60)$.

Range.-Eastern U. S., breeding from the Gulf to southern Canada; winters in Central America.

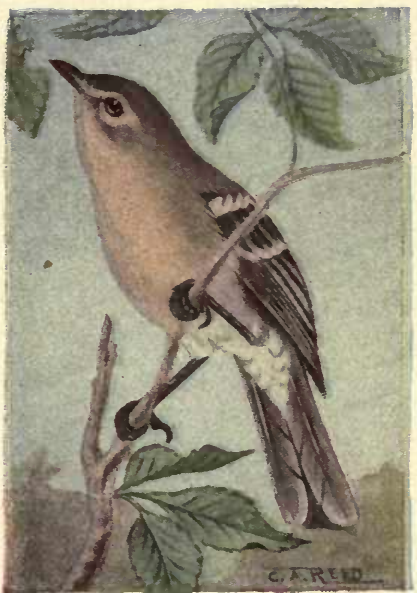

137 


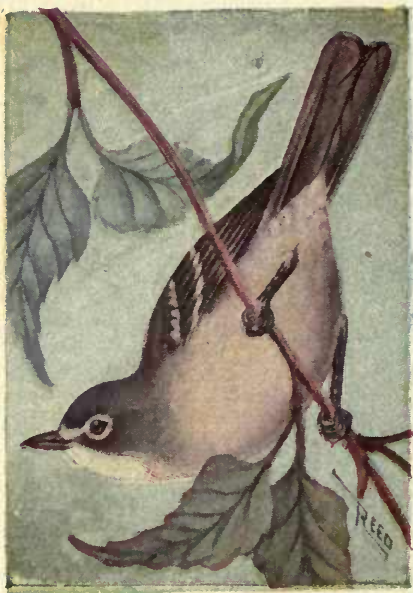

138

\section{BLUE-HEADED VIREO.}

629. Lanivireo solitarius. $5 \frac{3}{4}$ inches.

Crown and sides of head bluish slate; lores, eye-ring and underparts white; back and flanks greenish yellow; two whitish wing bars.

This species, to my eye, is the prettiest of the Vireos, all the colors being in just the right proportion and blending and harmonizing perfectly. They are solitary, in that they are usually found in deep woods, glens or ravines, and seldom is more than one pair found in a single woods.

Song.- Similar to that of the Yellow-throated Vireo but longer and more varied.

Nest.-A handsome, finely woven basket, with the outside covered with spider webs and often with lichens; eggs pale creamy white with chestnut specks.

Range.-Eastern N. A., breeding from the Gulf tc New Brunswick and Manitoba; winters south of the United States.

Sub-species.-629c. Mountain Solitary Vireo (alticola), head darker and back less greenish; Alleghanies from North Carolina to Georgia. 


\section{BLACK-CAPPED VIREO.}

630. Vireo atricapillus. $4 \frac{1}{2}$ inches.

Male, with crown and sides of head glossy black, lores and eye-ring white; female, duller colored.

This strange and comparatively rare Vireo frequents brushwood on the prairies of Kansas, Indian Territory and central and western Texas. Their habits in all respects resemble those of the more common Vireos or Greenlets as they are otherwise called.

Notes. - Similar to those of the White-eyed Vireo.

Nest.-Suspended as usual from forked branches at low elevations; made of fibres and bark strips closely woven together with spider webs. The four eggs are pure white, unmarked $(.70 \times .52)$.

Range.-Breeds from central and western Texas north to southern Kansas; winters in Mexico.

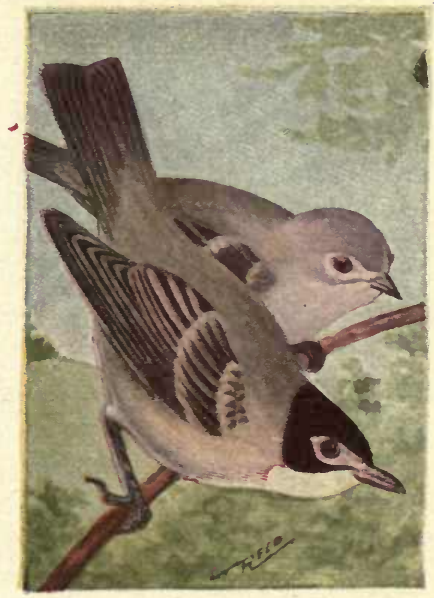

139 


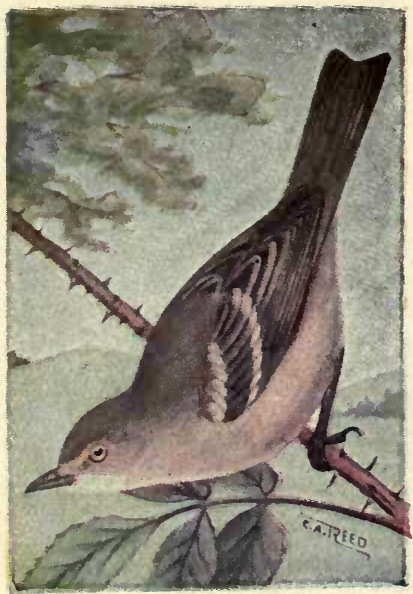

140

\section{WHITE-EYED VIREO.}

631. Viroo griseus. 5 inches.

This species shows a partiality for low, swampy places, covered with briars or tangled thickets of black. berry vines. Their habits are entirely different from any of the preceding Vireos. They do not seem to sing as they eat, but feed in silence, then, the task ended, mount to the tops of the brush and indulge in an endless variety of calls and whistles. notes.

Song.- A great variety of clear whistles and squeaky

Nesi.-A bulky structure of strips of bark, leaves, paper, etc., either placed in the branches or partially suspended in a fork; eggs white with minute brown specks $(.75 \times .55)$.

Range.-Eastern United States, breeding from the Gulf to Massachusetts and Manitoba; winters in Mexico.

Sub-species.-631a. Key West Vireo (maynardi), southern Florida. 631b. Bermuda White-eyed Vireo (bermudianus), resident in the Bermudas. 631c. Small White-eyed Vireo (micrus); southeastern Texas. 


\section{BLACK AND WHITE WARBLER.}

636. Iniotilta varia. $5 \frac{1}{4}$ inches.

Male, heavily streaked with black below; female, with only a few streaks on the sides.

These Warblers are usually known as Black and White Creepers because of their habit of creeping along the limbs and branches of trees. They are abundant in northern United States, being found in open woods, swamps and often in parks, gleaning insects and grubs from crevices in the bark.

Song. - A weak, thin, wiry "tsee, tsee, tsee."

Nest.-Of grasses and strips of bark on the ground at the foot of a stump or tree trunk or beside a rock; they lay four or five eggs, white with a wreath of reddish brown around the large end $(.65 \times .55)$.

Range.-Eastern N. A., breeding from Virginia and Louisiana north to Labrador and Hudson Bay; winters in northern South America.

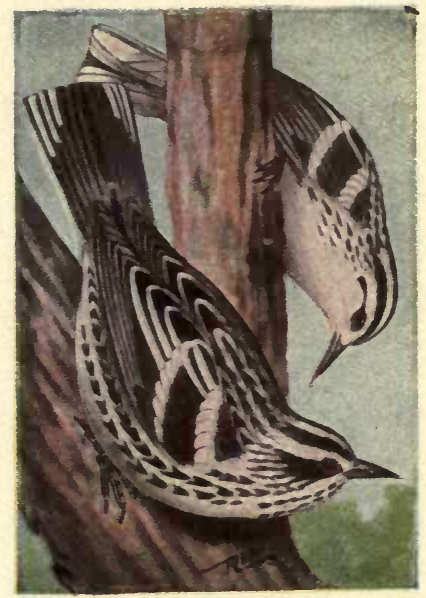

141 


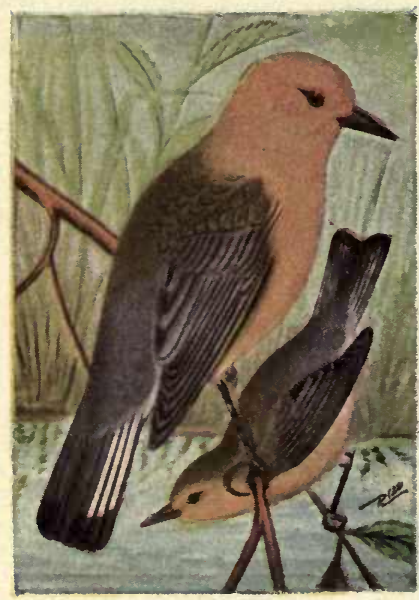

142

\section{PROTHONOTARY WARBLER.}

637. Protonotaria citrea. 51/4 inches.

Whole head and underparts intense yellow, almost orange on the head of the male; tail with white spots near the tip; female, duller.

A common species in the interior, found in bushy swamps and the willows around the borders of pools and lakes; they are found in the latter localities with Tree Swallows and often Chickadees all nesting in holes in hollow stubs along the bank, they being one of the few members of this family to make use of such locations for their nests.

Song.-A loud, ringing "tweet, tweet, tweet."

Nest.-In hollow stubs near or over water, the cavity of the stump being partially filled with moss, leaves and grasses hollowed on the top to receive the four to six creamy-white eggs which are heavily spotted over the entire surface with reddish brown $(.72 \times .55)$.

Range.-Eastern U. S., breeding from the Gulf north to Virginia, Illinois and Minnesota; winters in Central America. 


\section{SWAINSON WARBLER.}

638. Helinaia swainsonii. 5 inches.

Upper parts brownish; underparts whitish; a white superciliary stripe and a brown stripe through the eye. Some of the habits of this species are similar to those of the last but they are even more aquatic; they like swamps or stagnant pools thickly grown with rushes and tangled underbrush; unless cognizant of their habits, one would never look for a Warbler in the places frequented by these birds in company with Least Bitterns and Marsh Wrens. Until within a few years these were regarded as rare birds but are now found to be not uncommon in certain of the South Atlantic states, notably Georgia.

Song.-A series of descending, loud, clear whistles with a ventriloquial effect.

Nest.-Quite large structures consisting mostly of leaves with strips of bark, roots and pine needles. The four or five eggs are plain white, being the only eggs of American Warblers that are unmarkel.

Range.-Southeastern U. S. from Georgia to Louisiana and north to North Carolina and Missouri.

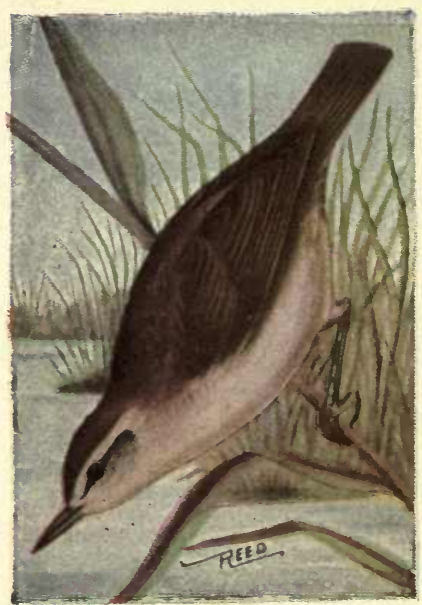

143 


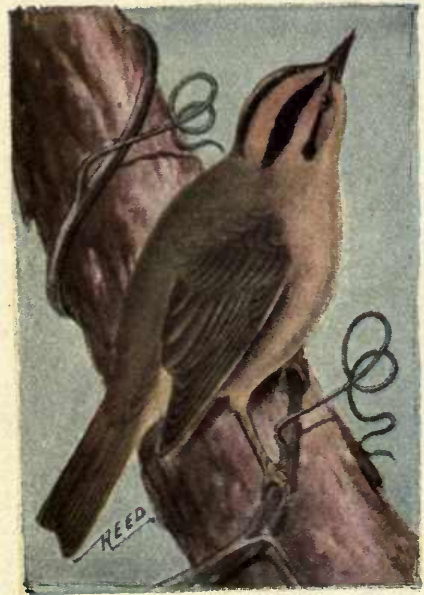

144

\section{WORM-EATING WARBLER.}

639. Helmitheros vermivorus. $51 \frac{1}{2}$ inches.

Crown buffy with two black stripes; back, wings and tail olive green with no white markings; below buffy white.

These birds are very unsuspicious and easy to approach; they spend the greater portion of their time on or near the ground; they are very fond of spiders and find quantities by overturning bits of bark and leaves. They also glean part of their living from the under side of the foliage much as do the Vireos. They are met with in open woods and brush-grown pastures.

Song.-A weak, rapid chipping.

Nest.-On the ground in depressions under logs, stones or bushes; of leaves and grass, lined with fine grass or hair; eggs four or five in number, white, spotted principally around the large end with brownish $(.70 \times .55)$.

Range.-Eastern U. S., breeding from the Gulf north to Connecticut, Ohio and Iowa; winters in Central America. 


\section{BACHMAN WARBLER.}

640. Vermivora bachmani. $41 / 4$ inches.

Male, with a yellow forehead, shoulders and underparts; black cap and breast patch; female, duller and with less black.

This species was first discovered by Dr. John Bachman near Charleston, S. C.

Song.-An insignificant warble or twitter, similar to the song of the Parula.

Nest.-In low bushes or briers, one to three feet above ground. Made of fine grasses and leaf skeletons, lined with black fibres. Found breeding by Widmann in Missouri, by Embody in Kentucky and by Wayne in South Carolina. Eggs 4 in number; pure white $(.63 \times$ .48).

Range.-Southeastern U. S., north to North Carolina and west to Missouri. Rare and local in distribution. 10

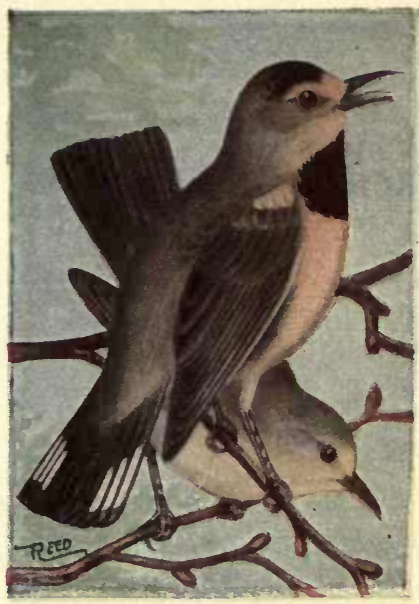

145 


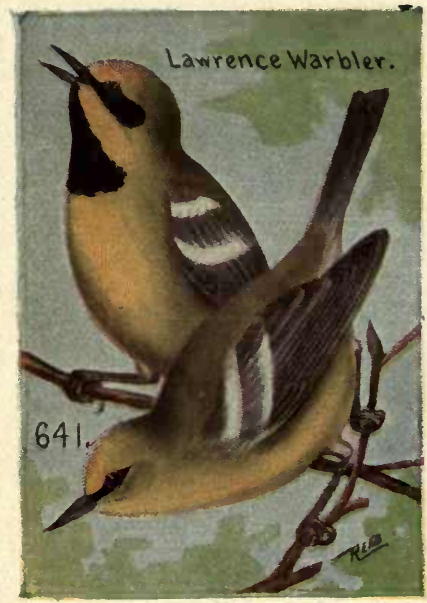

146
BLUE-WINGED WARBLER.

641. Vermivora pinus. $4 \% \frac{3}{4}$ inches.

Crown and underparts yellow; a narrow black line through the eyes; two broad whitish wing bars.

A common bird of the southeastern states and north to Connecticut, frequenting open woods, thickets and gardens. They are ground birds, spending most of their time on the ground or in low bushes which they clean of the insects which are destructive.

Song.-A loud, rapid chirrup, similar to that of the Grasshopper Sparrow but loud and distinct.

Nest.- Of leaves and strips of bark, lined with fine grasses; on the ground in clumps of weeds or blackberry vines; eggs white, sparingly spotted around the large end with rufous $(.65 \times .50)$.

Range.-Eastern U. S., breeding north to southern Connecticut and Wisconsin; winters in the tropics.

Hybrids.-Lawrence Warbler, which is a hybrid between this species and the next; it has the general plumage of this species with the black ear patches and throat of the Golden-winged Warbler. It is found chiefly in southwestern Connecticut and New York. 


\section{GOLDEN-WINGED WARBLER.}

642. Vermivora chrysoptera. 5 inches.

Crown and two large wing bars yellow; throat and ear patches black; rest of plumage gray and white; female with less black.

The distribution of this beautiful Warbler is about the same as that of the last, with which it seems to have many habits in common. It seems to prefer low ridges and side hills covered with small bushes.

Song. - A buzzing "zwee-ze-ze."

Nest.-Of leaves, rootlets, strips of bark and grass; located on the ground among clumps of weeds, usualty in moist places; eggs white with brown specks $(.62 \mathrm{x}$ $.48)$.

Range.-Eastern U. S., breeding north to Connecticut and Michigan; winters in Central America.

Hybrid.-Brewster Warbler is a hybrid between this species and the last. It resembles the Golden-winged Warbler without the black, but with a yellow patch on the breast and the black line of the Blue-wing through the eye.

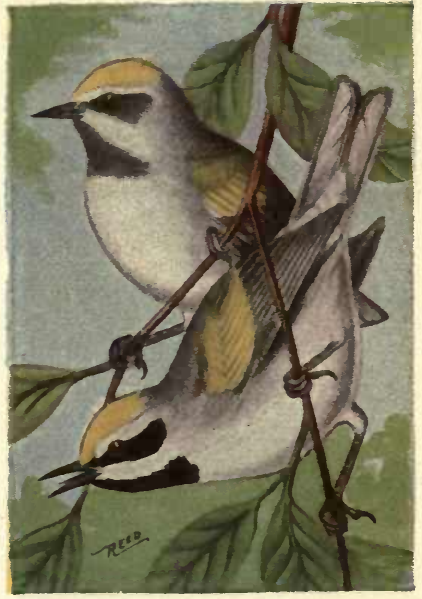




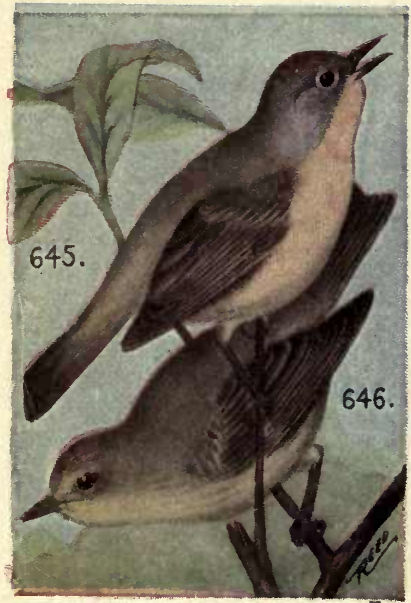

$\cdot 148$
NASHVILLE WARBLER.

645. Vermivora rubricapilla. $4 \% / 4$ inches.

Male with a brown crown patch; female duller colored and with no crown patch. Dry side hills covered with young trees are favorite resorts for the Warblers. They conceal their nests on the ground under tufts of dead grass or overhanging stones. They are often rather shy and hard to sight, but you can usually hear their song, a lazy sounding "ker-chip-chip-chip-cherr-wee-e-e," ending in a short trill. These birds breed in the northern half of the U. S. and southern Canada, wintering in Central America. A sub-species is found on the Pacific coast.

\section{ORANGE-CROWNED WARBLER.}

646. Vermivora celata. 5 inches.

This species is fairly common in the Mississippi Valley but is rare in New England. Its habits are much like those of the last species and it is often mistaken for that bird. These birds breed only north of the U. S. and winter in Mexico. A sub-species, the Lutescent Warblers, nests from California to Alaska. 


\section{TENNESSEE WARBLER.}

647. Vermivora peregrina. 5 inches.

Male, with a gray head and greenish back; female, with the top of the head the same color as the back.

A dull-colored bird that, with the exception of the bill, bears a strong resemblance to some of the Vireos. Like many others of our birds, this one has received an inappropriate name, because the first specimen was shot on the banks of the Cumberland River, while the bird is no more abundant in Tennessee than in other states during migration.

Song.-A simple ditty similar to that of the Chipping Sparrow.

Nest.-Either on the ground or at low elevations in bushes; of grasses and fibres lined with hair; eggs white, sparsely specked with reddish brown $(.62 \times .45)$.

Range.-Eastern N. A., breeding from the northern parts of the northern tier of states northward to the limit of trees; winters in Central and South America.

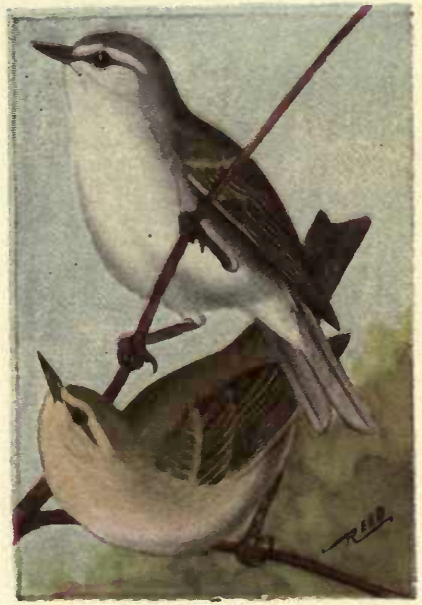

149 


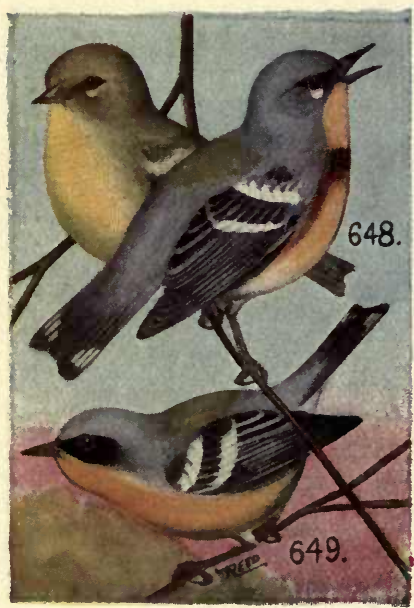

150
PARULA WARBLER.

648. Compsothlypis americana. $41 \frac{1}{2}$ inches.

In the summer Parulas are found in wet swamps where the ground is covered with a carpeting of moss which only partially keeps your feet from the water below; the dead trees are covered with a growth of long, drooping moss; the ends of this moss are turned up and formed into a neat cradle within which the eggs are laid.

Song.-A little lisping trill.

Range.-Breeds in the southern half of the U. S. The Northern Parula (usnea), No. 648a, breeds in the northern half of the U.S. and southern Canada; it is brighter colored than the southern form. Both varieties winter from the Gulf States southward.

\section{SENNETT WARBLER.}

649. Compsothlypis pitiayumi nigrilora. $4 \frac{1}{2}$ inches.

A smaller similar bird from southern Texas. Note the black ear patches and lack of black on breast. 


\section{CAPE MAY WARBLER.}

650. Dendroica tigrina. 5 inches.

Male, with a chestnut wash on the ears and throat; female, duller and with little or no chestnut.

In the greater part of eastern North America, Cape May Warblers are regarded as rare birds; they appear to migrate in compact bodies, not spreading out over the country as do most of the others; consequently they may be very common in restricted areas while lacking entirely in others. I have never met with but two specimens in Massachusetts. While passing through the United States you may meet with them in open woods, parks or in shade trees along the streets of cities.

Song.-A thin, high-pitched whistle repeated several times.

Nest.-Of small cedar twigs lined with horse hair, placed within a few feet of the ground in small cedar trees; eggs white spotted with brown $(.68 \times .50)$.

Range.-Eastern N. A., breeding in eastern Canada and, rarely, northern New England; winters south of the U. S.

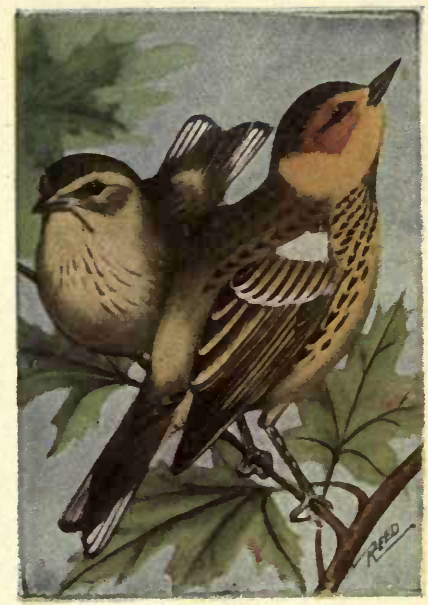

151 


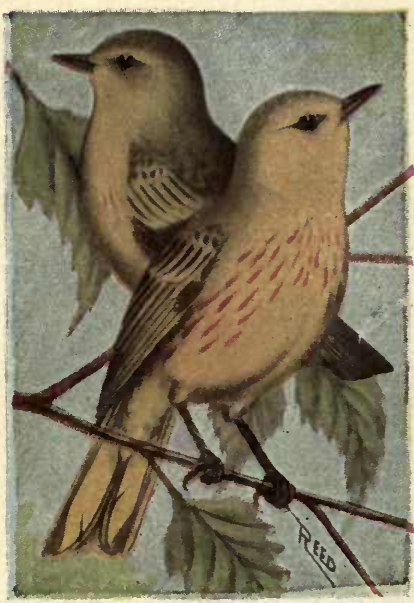

152

\section{YELLOW WARBLER.}

652. Dendroica astiva. 5 inches.

Male, with chestnut streaks on the sides; female, duller and without the streaks.

An abundant bird everywhere in woodland, park, orchard or garden and one of the most vivacious of the family. Arrives in the north soon after May first and is seen flitting about like a gleam of sunshine snatching insects from the foliage or darting after them in the air. Often known as the Summer Yellowbird. It frequently nests in garden or orchard trees, where it is a most welcome tenant.

Song.-A sharp, vigorous "che-wee, che-wee, che-wee."

Nest. -A beautiful and compact structure of vegetable or plant fibres firmly quilted together, and fastened to upright forks of bushes or trees at low elevatíons. Willows along creeks, ponds or rivers are favorite resorts.

Range.-N. A., breeding from the Gulf to Labrador and Alaska; winters in Central America. 
BLACK-THROATED BLUE WARBLER.

654. Dendroica corulescens. 51/4 inches.

Male, grayish blue above and with a black face, throat, breast and sides; female, grayish olive above, whitish below. Both sexes always have a white patch or speck at the base of the primaries.

You will find these birds in damp woods or swamps, or less often in parks or open woods. They are usually seen at low elevations in scrubby underbrush. Their notes are very peculiar and will draw attention to them anywhere.

Song.-A deep grating whistle with a sharply rising inflection, "zee-zee-zwee."

Nest.-In deep, swampy woods, especially common in laurel; of grape vine bark and rootlets lined with fine black roots and hair; the four eggs are white or buffy white with reddish-brown spots and blotches.

Range.-Eastern N. A., breeding from Connecticut (sparingly) and Michigan north to Labrador and Hudson Bay; winters in Central America. 654a. Cairns Warbler (cairnsi) is said to be darker on the back; found in the southern Alleghanies.

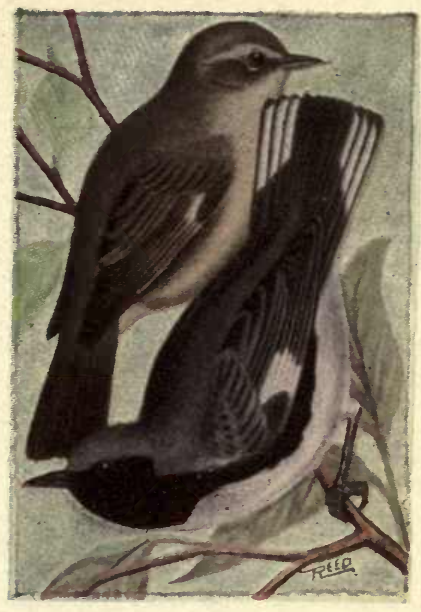

153 


\section{MAGNOLIA WARBLER.}

657. Dendroica magnolia. 5 inches.

Male, with black ear patch, back, and necklace; female, with the black replaced with grayish; both sexes have a yellow rump and white spots midway of the tail feathers.

One of the prettiest of the Warblers and one of the least timid. I have often had one or more of these birds follow me the whole length of a piece of woods apparently out of curiosity, coming down to the nearest twigs within arms' reach of me. Birch woods are their favorites during migrations, although a few of them will be found almost anywhere.

Song. - A short, rapidly uttered warble.

Nest.-Usually in coniferous trees, far out on the longer branches, where they are often difficult to get at; of rootlets lined with fine black rootlets and hair; four or five white eggs with small spots of ehestnut around the large end (.60 $\mathrm{x} .48)$.

Range.-Eastern N. A., breeding from Massachusetts and Michigan northward; winters south of the U. S.

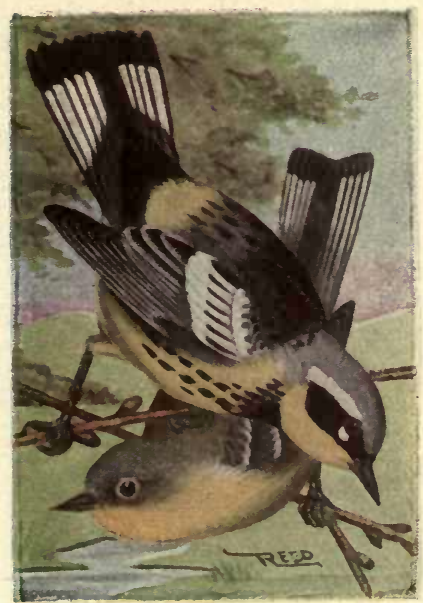

155 


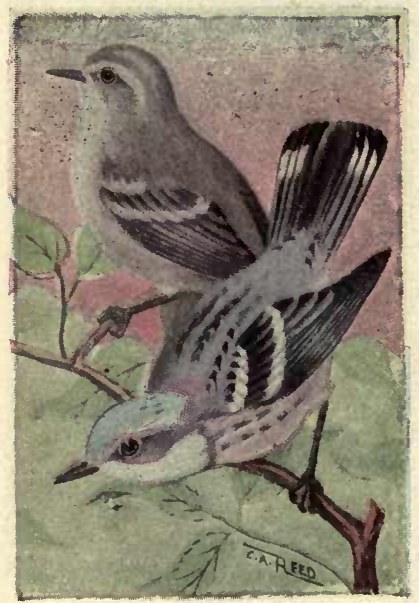

156

\section{CERULEAN WARBLER.}

658. Dendroica cærulea. 5 inclies.

Above grayish blue with black streaks, below white with a bluish breast band and streaks on the sides; female washed with greenish above and yellowish below; both have white patches near the ends of the tail feathers.

These dainty little Warblers are not abundant anywhere, but seem to be most so in the central states. They are birds of the tree tops, rarely coming down so that they can be distinctly seen. They may be more common than supposed, for so small a body at such heights can readily be orerlooked.

Song.-A little warbling trill, "zee-zee-ze-ee-eep."

Nest.-In the higher outer branches of large trees usually in deep woods; compactly made of dry grasses and cobwebs, adorned with a few lichens; eggs white specked at the large end with brownish $(.65 \times .50)$.

Range.-Interior portions of the U. S., breeding north to Michigan and Minnesota; east to western New York and, rarely, southern New England; winters ir. northern South America. 
CHESTNUT-SIDED WARBLER.

65.9. Dendroica pensylvanica. 5 inches.

Yellow crown, black line through eye and on side of throat, and broad chestnut stripe on sides; female, paler and with less chestnut; young greenish yellow above and with no chestnut.

Nearly everry swamp or bush-covered pasture within their range shelters one or more pairs of these Warblers. While they sometimes feed in the tree tops, they are birds of the lower foliage and are usually seen in low bushes.

Song.-Similar to that of the Yellow Warbler but more choppy.

Nest. - In low bushes or weeds, and often in sweet fern or briars; similar to that of the Yellow Warbler but coarser, being made more with grasses than with fibres, situated in upright forks or attached to several weed stalks; eggs white, specked around the large end with reddish brown $(.68 \times .50)$.

Range.-Eastern N. A., breeding from New Jersey and Ohio north to Manitoba and New Brunswick; winters south of U. S.

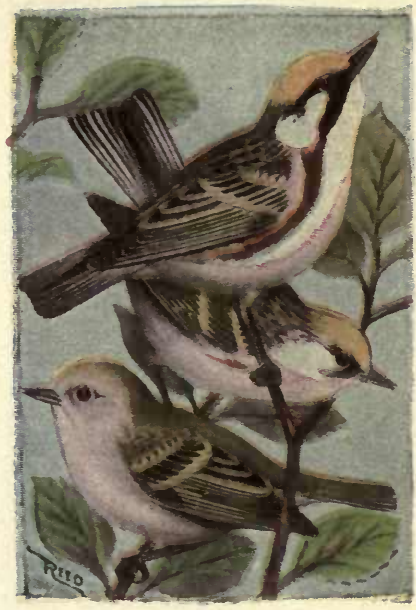

157 


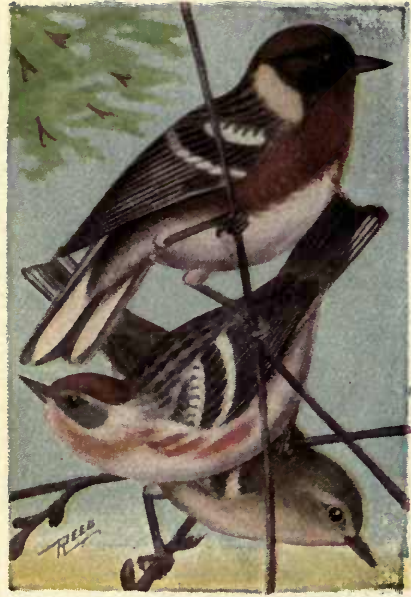

158

\section{BAY-BREASTED WARBLER.}

660. Dendroica castanea. 51/2 inches.

Male, with crown, throat and sides rich chestnut; female, paler; young and adults in winter, greenish above, streaked with black and with a trace of chestnut on the flanks.

These Warblers are only locally abundant during migrations, while in eastern New England they are rare. They are active insect hunters, darting rapidly about the tree tops or, less often, in brush; their habits most nearly resemble those of the Chestnut-sided Warbler.

Song.-A low, liquid warble.

Nest.-At low elevations in trees in swampy woods; compact, cup-shaped structures made of fine shreds of bark, rootlets and grass; eggs bluish white, finely specked around the large end with reddish brown $(.70 \mathrm{x}$ $.50)$.

Range.-Eastern N. A., breeding from the northern edge of the U.S. northward; winters south of the U. S. 
BLACKBURNIAN WARBLER.

662. Dendroica fusca. $51 / 4$ inches.

Male, black above with large white patch on wing, and bases of outer tail feathers white; throat and oreast intense orange; female, duller and with the orange replaced by dull yellow.

Without exception, this is the most exquisite of the whole family; it is the most eagerly sought bird by bird lovers, in the spring. Some years they are very abundant, while others few are seen, their routes of migration evidently varying. They arrive about the time that apple trees are in bloom, and are frequently seen among the blossoms, dashing after insects.

Song.-A high-pitched lisping "zwe-zwe-zwe-see-ee-ee," ending in a thin, wiry tone, almost a hiss; it is very distinct from the song of any other bird.

Nest.-In coniferous trees at any height from the ground; of shreds of bark, fine cedar twigs, rootlets, etc.; eggs greenish white blotched with brown.

Range.-Eastern N. A., breeding from Massachusetts (rarely) and Minnesota northward; winters in Central America.

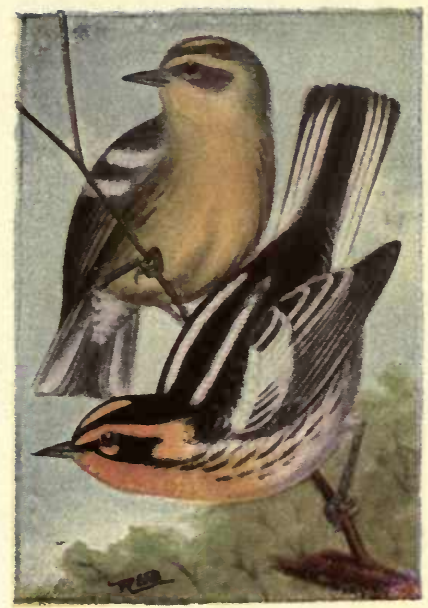

$15 \%$ 


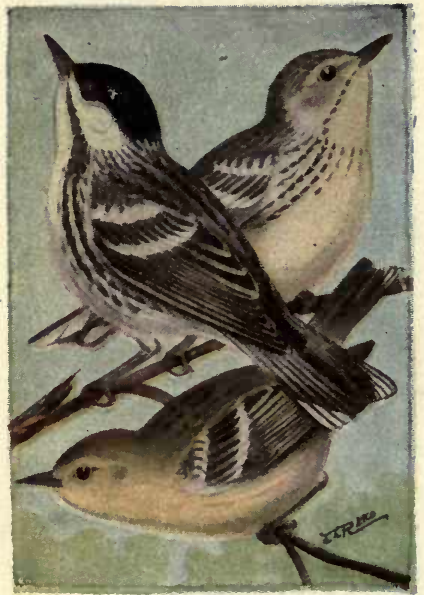

160
BLACK-POLL WARBLER.

661. Dendroica striata. $51 / 2$ inches.

Whole crown black; female, without black cap, greenish gray above streaked with black; young paler than the female.

These birds are one of the latest of the migrants to arrive, reaching northern United States about the last of May, but coming in such numbers that they are found everywhere. While their plumage somewhat resembles that of the Black and White Warbler, their habits are entirely different.

Song.-A high-pitched, hissing whistle similar to that of the Black and White Warbler but uttered more deliberately and with an instant's pause between each note.

Nest.-At low elevations in thick coniferous trees; made of slender twigs, rootlets and lichens, lined with hair or feathers; eggs whitish, thickly spotted with brown $(.75 \times .52)$.

Range.-Eastern N. A., breeding from northern New England, Minnesota and Wyoming north to the Arctic regions; winters south of the United States. 
YELLOW-THROATED WARBLER.

663. Dendroica dominica. 51/4 inches.

Throat, breast and line from eye to bill yellow.

This species has habits very similar to those. of the Black and White Creeper, being often seen creeping around the trunks or over the branches of trees with almost as much facility as the Nuthatches. They are southern birds and are only rarely or accidentally found in the northern half of the U.S., and they are one of the few members of the family that winter in the southern parts of our country.

Song.-Loud and similar to that of the Indigo Bunting, but shorter.

Nest.-Usually high up in pines and often concealed in tufts of moss; made of fine twigs and strips of bark, held together with cobwebs and Spanish moss; eggs greenish white, spotted with various shades of brown.

Range.-Southeastern U. S., breeding north to Virginia; winters in the West Indies. 663a. Sycamore Warbler (albilora) is like the Yellow-throated, but is white before the eye; found in the Mississippi Valley north to Illinois and Iowa; winters in Mexico.

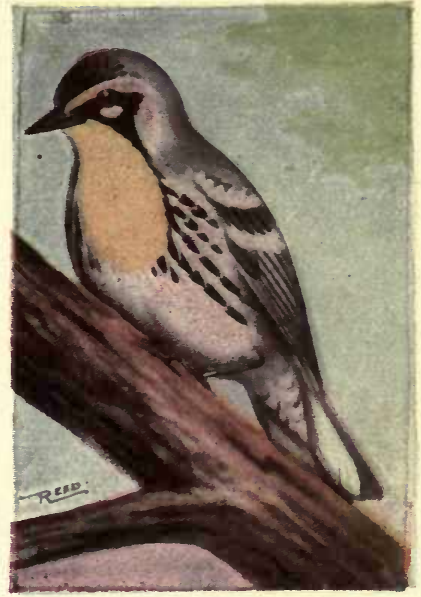

16] 


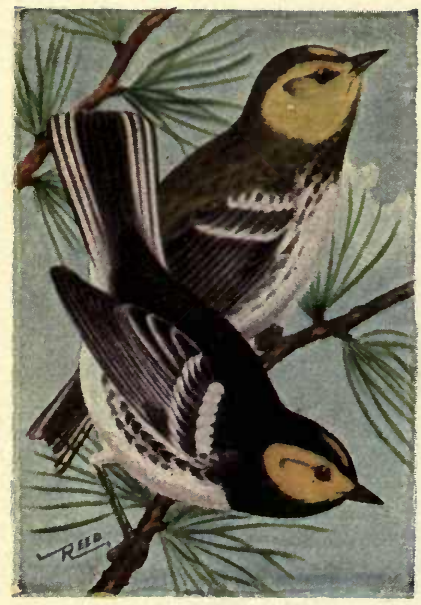

162

\section{GOLDEN-CHEEKED WARBLER.}

666. Dendroica chrysoparia. $4 \frac{3}{4}$ inches.

In some plumages these birds may be confused with the Black-throated Green. Notice that the adult male has a short median line of yellow on the crown, otherwise the top of head and entire back are intense black. Young birds, which bear the closest resemblance to the next species, can be distinguished because their underparts are white, those of the Black-throated Green being tinged with yellow.

These rare Warblers have a very restricted distribution, but are said to be not uncommon within their range. Notes.-Song with the usual Warbler quality, but entirely distinctive: "sweah-sweah-swee-e-e."

Nest.-Of strips of bark, usually located in juniper trees six to twenty feet above ground. Eggs white, splashec about the large end with reddish brown (.65 x.56, .

Range.-Central Texas southward into Mexico. 


\section{BLACK-THROATED GREEN WARBLER.}

667. Dendroica virens. 5 inches.

Throat black; two wing bars and outer tail feathers white; female with little black on the throat.

A common bird in pine groves in northern United States, or during migrations in birch woods. I have found them most abundant on side hills covered with low-growth pines. They seem to be very nervous and are greatly excited if you appear near their nests. They often have the habit of building several nests, whether with the deliberate intent to deceive or whether because the first was not satisfactory as to location is not known.

Song.-Entirely different from that of any other bird; a rather harsh "zee" repeated six times, with the fourth and fifth syllables lower.

Nest. - Of rootlets and fine grasses, lined with hair; placed high up in pine trees; eggs white with fine brown specks around the large end $(.60 \times .50)$.

Range.-Eastern North America, breeding from southern New England and Illinois north to Nova Scotia and Hudson Bay; winters in Central America.

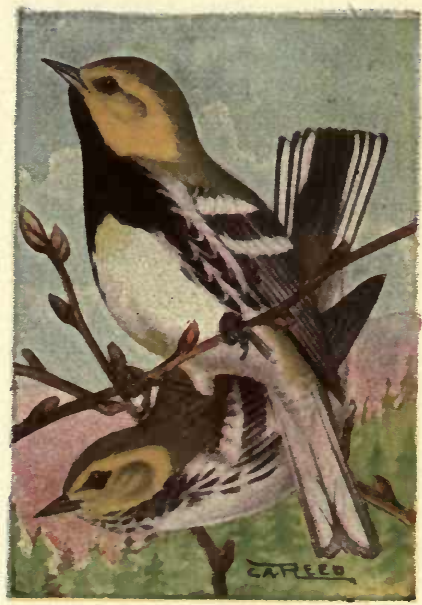




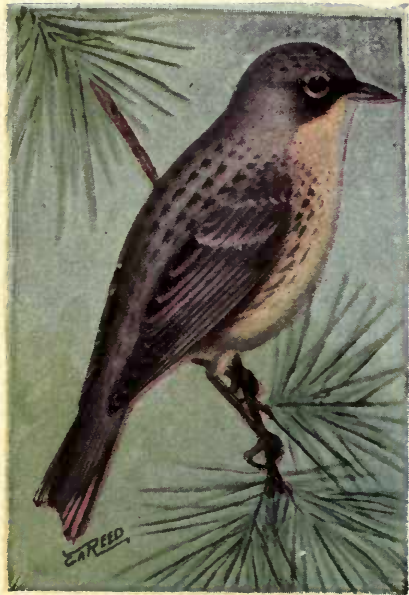

164

\section{KIRTLAND WARBLER.}

670. Dendroica kirtlandi. $51 / 2$ inches.

Above bluish gray streaked with black; underparts pale yellow streaked on the side with black.

This is one of the rarest of American Warblers, and until 1903 but little was known of their habits or range; in that year they were discovered nesting in Oscoda County, Michigan. They were found near the banks of a river in Jack pines, building on the ground and remaining in the underbrush near it.

Song.-Loud and clear and said to resemble that of the Maryland Yellow-throat.

Nest.-In depressions in the ground at the foot of pine trees and probably also under bushes; made of strips of bark and vegetable fibres; eggs white, wreathed about the large end with brown $(.72 \times .56)$.

Range.-Breeds in Michigan and migrates southeast through Ohio, Missouri, Tennessee, Virginia, the Carolinas and Florida to the Bahamas. 


\section{PINE WARBLER.}

671. Dendroica vigorsi. $51 / 2$ inches.

Greenish yellow above, brighter below; two white wing bars and white spots on outer tail feathers; female, duller and grayer.

Found only in tracts of coniferous trees, except during migrations, when they are often in company with other kinds of Warblers. They like dry hillsides covered with scrub pines and are often quite abundant in such localities. They are rather quiet in their manners, creeping about among the tree tops like Black and White Warblers and occasionally giving their clear little trill.

Song.-Nearest like that of the Chipping Sparrow, but easily distinguishable; a long, clear trill.

Nest.-A small, compact structure of black rootlets lined with hair; placed in the extreme tops of scrub pines, where it is very difficult to see them; eggs white specked with reddish brown $(.62 \times .50)$.

Range.-Eastern N. A., breeding from the Gulf north to southern Canada; winters in southern U.S.

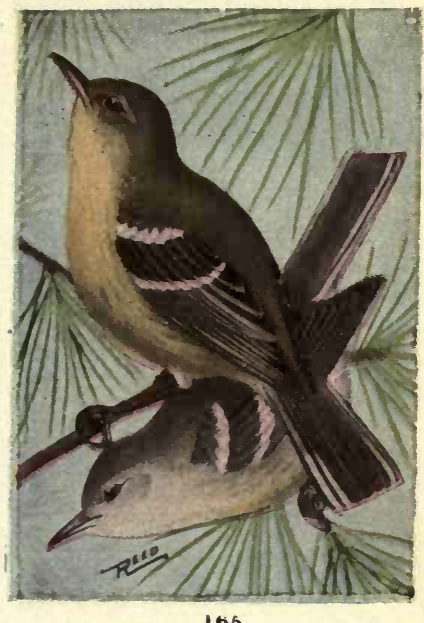

Iths 


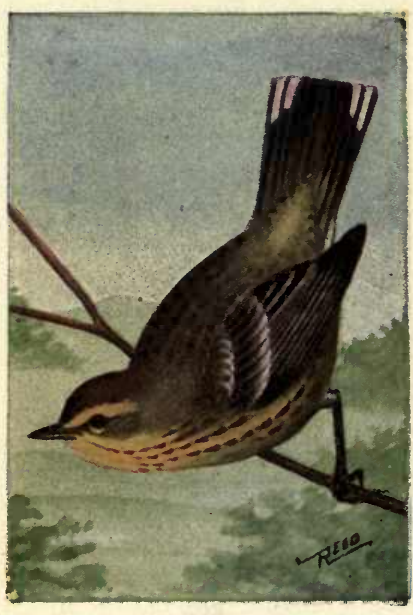

166
PALM WARBLER.

672. Dendroica palmarum. $51 / 4$ inches.

No wing bars, but white spots on the outer tail feathers; crown, cheeks and streaks on the sides chestnut.

During migrations you will find these Warblers along roadsides, in open woods and scrubby pastures. They are of a very nervous temperament and, when at rest or when walking, are continually flirting their tail, a habit which none of the Warblers, except the Water-thrush, seem to have. They are one of the earliest of the family to appear in the spring, reaching northern United States in April.

Song.-A short trill; an ordinary Warbler chirp.

Nest.- Un the ground under shrubs, or sunken in moss; made of fine grasses, bark and moss; the four eggs are creamy white with reddish-brown spots.

Range.-Interior of N. A., breeding in the interior of British America; winters in southern U. S. 672a. Yellow Palm Warbler (hypochrysea) is brighter yellow below; it is found in eastern N. A., breeding north of Nova Scotia; winters along the Gulf. 


\section{PRAIRIE WARBLER.}

673. Dendroica discolor. $4 \frac{3}{4}$ inches.

Above greenish with chestnut spots on the back; below yellow with black markings; female paler.

These are very locally distributed birds and will often be found breeding abundantly in a small patch of brushcovered pasture, while many others apparently just as well suited for their purposes will be shunned by them. They are very active, flitting rapidly from one bush to another, the male occasionally mounting to a bush top to hurriedly deliver his song, then diving out of sight below the foliage.

Song.-An energetic, rather harsh "zee-zee-zee-ee" on an ascending scale.

Nest.-A neat cup of grasses and vegetable fibres, lined with black rootlets or horsehair; located in low shrubs or bushes from one to two feet above ground; eggs whitish with blackish-brown specks about the large end $(.65 \times .48)$.

Range.-Eastern U. S., breeding from the Gulf to Massachusetts and southern Michigan; winters in the West Indies.

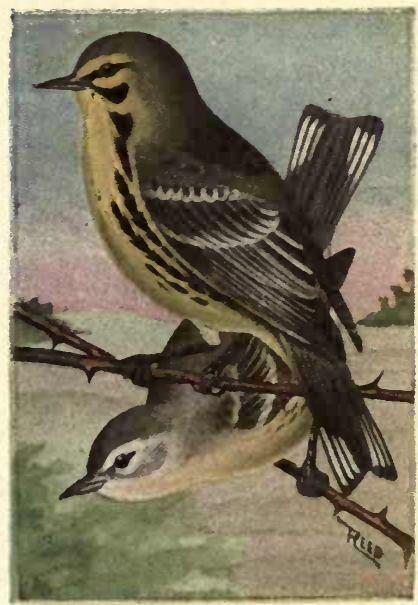

107 


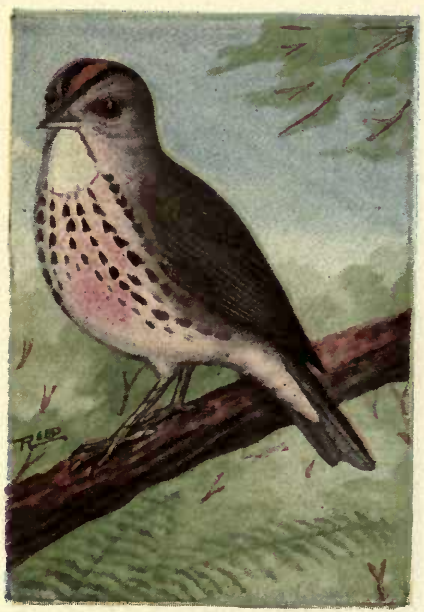

168

\section{OVEN-BIRD.}

674. Seiurus aurocapillus. 6 inches.

Crown orange brown bordered by black; no white in wings or tail.

This bird is found in open woods, where it builds its arched nest on the ground among the leaves or pine needles. It is the peculiar oven-like construction of their nests that gives them their name. They are essentially ground birds, only mounting to the lower branches of trees to sing or when scolding an intruder.

Song.-A peculiar ascending song resembling the word teacher, repeated five or six times and gathering strength and volume with each syllable; call, a sharp chip.

Nest.-Of leaves, strips of bark and grass arched over the top so as to leave a very small opening; placed on the ground in woods; four to six white eggs spotted with reddish brown $(.78 \times .58)$.

Range.-Eastern N. A., breeding in the northern half of the U. S. and north to Labrador; winters chiefly south of U.S. 


\section{WATER-THROSH.}

675. Seiurus noveboracensis. 6 inches.

This species always has a yellowish tinge to the underparts and the stripes beneath are narrow, but prominent. These Warblers are found in tangled underbrush near water. They have a habit of continually flirting their tails, thus giving them the local name of Water-Wagtail. Their call is a sharp metallic "chink"; their song a loud, liquid "quit-quit-quit-que-quewe-u." Breeds from the northern edge of the U.S. northwards; winters south of U. S.

\section{LOUISIANA WATER-THRUSH.}

676. Seiurus motacilla. 61/4 inches.

Larger, grayer above and whiter below than the preceding; stripes fewer and broader. This is a more southern species and breeds from the Gulf to Connecticut and southern Minnesota. Its notes are wild and ringing, like those of the last. They build their nests under the roots of trees or under the edges of overhanging banks. The eggs are creamy white, boldly blotched with brown.

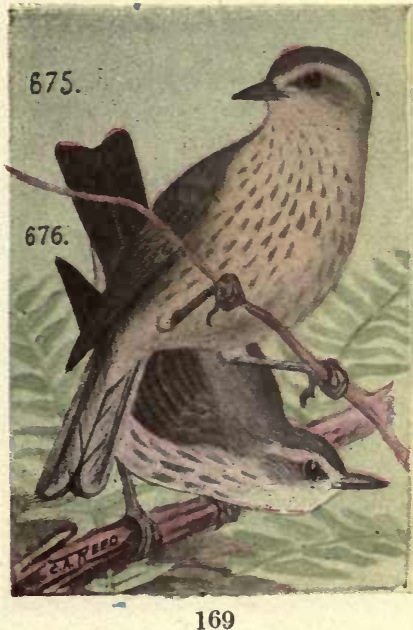




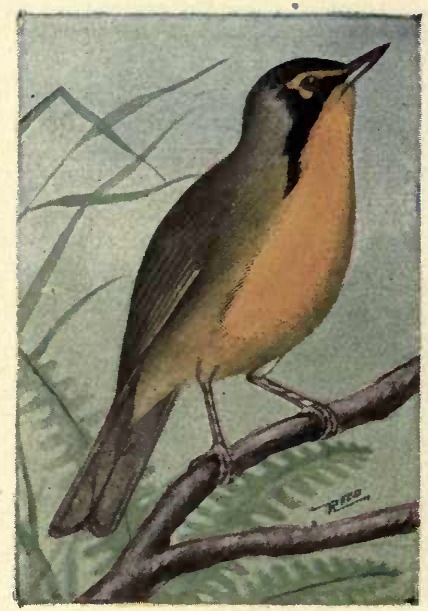

170
KENTUCKY WARBLER.
677. Oporornis formosa. $5 \frac{1 / 2}{2}$ inches.

Crown and ear coverts black, underparts and line over eye yellow; no white in the plumage.

These birds are found in about such localities as are frequented by Ovenbirds, but with a preference for woods which are low and damp. They are locally common in some of the southern and central states. They are active gleaners of the underbrush, keeping well within the depths of tangled thickets. Like the Maryland Yellow-throat, which has similar habits to those of this bird, they are quite inquisitive and frequently come close to you to investigate or to scold.

Song.-A loud, musical, Wren-like warble.

Nest.-A bulky structure of leaves, bark and grasses, lined with black rootlets or horsehair; placed on the ground in bunches of weeds or at the foot of a small bush; the four or five eggs are quite heavily speckled, chiefly at the large end, with reddish brown.

Range.-Eastern U. S., breeding from the Gulf north to New York and southern Michigan; winters in northern South America. 
CONNECTICUT WARBLER.

678. Oporornis agilis. 51/2 inches.

Male with a bluish slate-colored head; eye ring white and completely encircling the eye; female with a saffroncolored head.

In the United States we find this Warbler only in spring and fall migrations. They appear to be much more rare in the spring than in the fall; while I have seen perhaps a hundred in the fall I have never seen but one in spring. They frequent wild tangled thickets, such as you often find Maryland Yellow-throats in. As they do most of their feeding upon the ground and remain in the depths of the thickets, they are rarely seen unless attention is drawn to them.

Song.- Somewhat like that of the Maryland Yellowthroat; call, a sharp, metallic "peenk."

Nest.-In thickets or clumps of briars, either on the ground or just above it; made of strips of bark and skeletons of leaves, lined with hair; eggs whitish sparingly specked at the large end with brown $(.75 \times .56)$. Range.-Eastern N. A., breeding north of the U. S.; winters in northern South America.

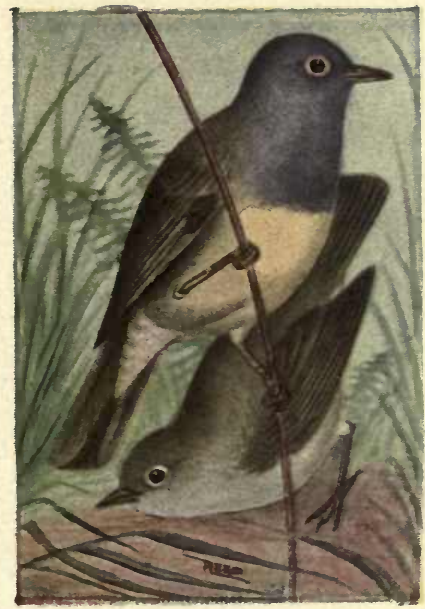

171 


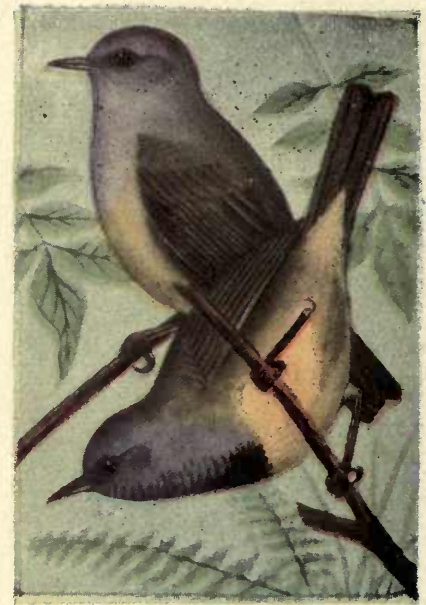

172

\section{MOURNING WARBLER.}

679. Oporornis philadelphia. $51 / 2$ inches.

Similar to the last, but with no eye ring and with a black patch on the breast.

These birds are found in swamps and thickets, as well as among the bushes and weeds along walls, fences and the edges of woods. Their habits are like those of the Maryland Yellow-throats, they being found on or near the ground, scratching about among the leaves or gleaning insects from the foliage of the low shrubbery. They appear to be the most abundant in the middle States and northward.

Song.-Similar to the liquid song of the WaterThrush; call, a sharp "peenk," like that of the last.

Nest.-On or near the ground in thickets or tangled vines; made of fine bark strips and fibres, lined with hair; eggs white specked with reddish brown (.71 x.54). Range.-Eastern U. S., breeding from northern New England, Ohio and Michigan north to southern Canada; winters south of the U. S. 
MARYLAND YELLOW-THROAT.

68i. Geothlypis trichas. 51/4 inches.

One of our most common birds in swamps and also in shrubbery along roadsides or walls. They are very inquisitive, and their bright eyes will peek at you from behind some leaf or shrub as long as you are in sight.

Song.-A lively "witchity-witchity-witch"; call, a deep chip; also a rattling note of alarm.

Nest.-Of grapevine and grasses, located in clumps of weeds on or nearly touching the ground; eggs white with brown specks $(.70 \times .50)$.

Range.-Eastern N. A., breeding from the Gulf to New Jersey.

Sub-species.-68la. Western Yellow-throat (occidentalis), said to be brighter; found chiefly west of the Rockies, but east to the Plains. 681b. Florida Yellowthroat (ignota), South Atlantic and Gulf coasts. 681d. Northern Yellow-throat (brachidactyla), slightly larger and deeper colored; found in northeastern U. S. and southeastern Canada, west to Dakota and south through the Mississippi Valley to the Gulf.

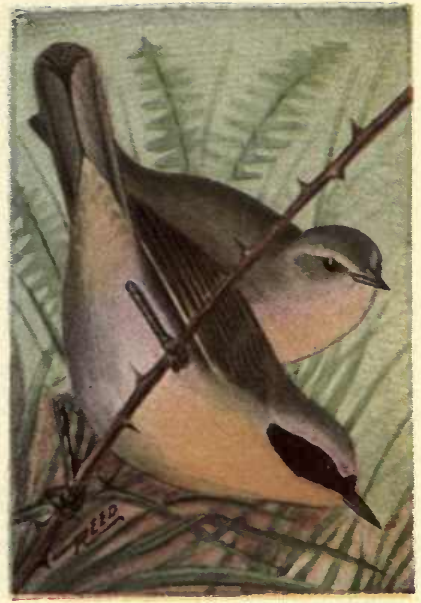

173 


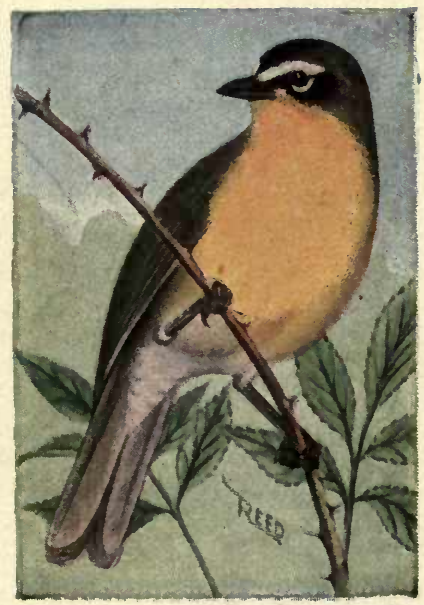

174

\section{YELLOW-BREASTED CHAT.}

683. Icteria virens. $71 / 2$ inches.

Breast yellow, lores black, line over the eye and underparts white; no white on wings or tail.

Dry side hills and ravines covered with thick under brush are the places to look for Chats. Usually if they are present they will make themselves heard long before you see them. They are one of the most odd birds both in action and song. They are mimics of the highest order and can make any kind of whistle or squawk, but all their vocal efforts seem to require a great deal of flirting of the tail and twisting of the head. They even jerk their tail up and down while flying, this making them appear extremely ludicrous.

Songs.-A varied medley of whistles and calls.

Nest.-Near the ground in tangled thickets; of grass, weeds, etc.; eggs whitish plentifully specked with reddish brown $(.90 \times .70)$.

Range.-Eastern U. S., breeding north to Massachusetts and southern Minnesota; winters in Central America. 683a. Long-tailed Chat (longicauda) is found in the U. S. from the Plains to the Pacific. 


\section{HOODED WARBLER.}

684. Wilsonia citrina. $5 \frac{1}{2}$ inches.

Male with yellow forehead and cheeks, the rest of the head and throat being black; female much duller with little or no black; both sexes have white spots on the outer tail feathers, but no bars on the wings.

This is one of the liveliest of the family, being very active in catching insects on the wing like a true Flycatcher; because of this habit all the members of this genus are often called Fly-catching Warblers. They also have a habit of often spreading and folding the tail as they flit through the underbrush that they frequent.

Song.-A clear, liquid series of whistles; call, a sharp "chip."

Nest.-Within a few inches of the ground in low underbrush or vines; made of leaves, bark, etc., held firmly together with cobwebs; the four or five eggs are white, profusely spotted with reddish brown.

Range.-Eastern U. S., breeding from the Gulf to southern Connecticut and Michigan; winters south of the U. S.

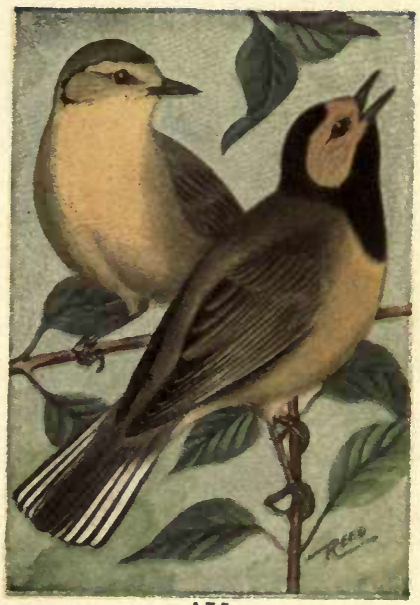




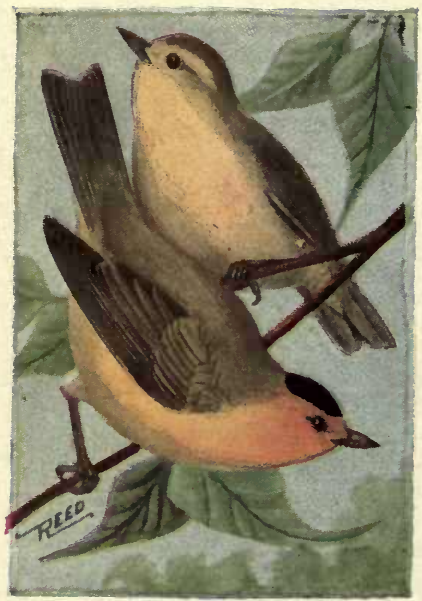

176

\section{WILSON WARBLER.}

685. Wilsonia pusilla. 5 inches.

Male, with black crown patch; female, with the crown greenish like the back.

These little fy-catching Warblers are abundant in the United States during migrations, being found in woods or swamps, and very often in apple trees when they are in bloom. They fly about among the outer branches snatching insects from the foliage or blossoms, and often dashing out to eatch one that is flying by. Their natural pertness is intensified by their very attractive plumage which harmonizes perfectly with green leaves.

Song.-A simple and rather weak trill.

Nest.-Of leaves and bark, imbedded in the ground under bushes on the edges of swamps or woods; eggs white, specked with reddish brown $(.60 \times .48)$.

Range.-Eastern N. A., breeding from the northern edge of the U. S. northward; winters in Central America Two sub-species are found west of the Rockies. 


\section{CANADIAN WARBLER.}

686. Wilsonia canadensis. $51 / 2$ inches.

Male, with a necklace of black spots, white eye ring and lores; female, and young, with only a slight indication of the necklace.

These Warblers travel northward in company with many other kinds, always keeping in the underbrush near the ground, except when they come out into orchards and parks. Like the two last, they are very lively, rarely remaining still for more than a few seconds, before they must dash after some tempting morsel that is flying by.

Song.-A loud liquid warble, most nearly resembling that of the Water-Thrush; call, a sharp, querulous chip.

Nest.-Of rootlets and strips of bark, under roots of trees or shrubs or at the foot of stumps in the moss; the four eggs are white with a wreath of chestnut spots around the large end $(.68 \times .50)$.

Range.-Eastern N. A., breeding from Massachusetts and Michigan northward; winters in northern South America.

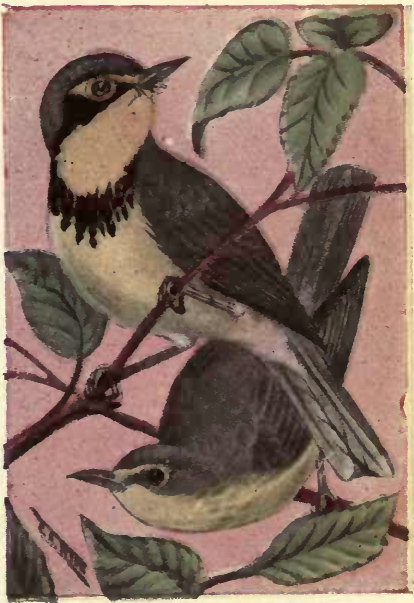

177 


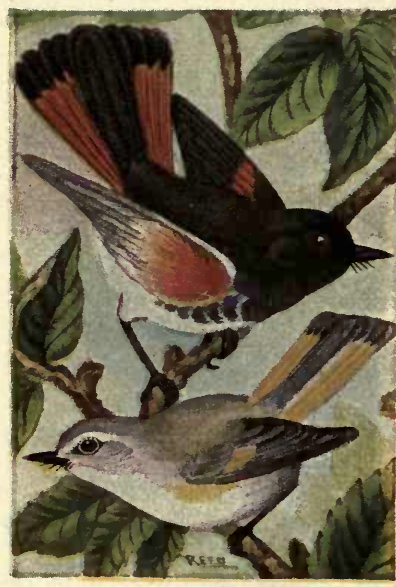

178
AMERICAN REDSTART.

687. Setophaga ruticilla. $51 / 2$ inches.

Male, black, orange and whitø; female, grayish, yellow and white; it requires two or three years to attain the black plumage of the male, in the intermediate stages they are sometimes strangely mottled.

In the northeastern half of the United States, these are one of the commonest and most active of the species. Both the males and females seem to be proud of their handsome plumage and are continually spreading and closing their tails. They are equally happy whether in the tree tops or near the ground, and are as often found in the one place as the other.

Song.- "Che-wee, che-wee, che-wee," very similar to that of the Yellow Warbler and also the Chestnut-sided Warbler.

Nest.-Of plant fibres and grasses in forks of bushes or trees, usually at greater heights than those of the Yellow Warbler; eggs whitish specked with brown.

Range.-N. A., rare west of the Rockies, breeding from North Carolina and Missouri northward; winters south of the U. S, 
AMERICAN PIPIT; TITLARK.

697. Anthus rubescens. $61 / 2$ inches.

These are Arctic birds that spend the winter months in the United States. We find them in flocks along roadsides or in fields, feeding upon weed seeds. They are shy and take wing readily, uttering sharp whistles as they wheel about in the air. They are always restless and stay in a place but a short time. They nest on the ground in northern Canada. Eggs grayish, profusely specked with brown.

\section{SPRAGUE PIPIT.}

700. Anthus spraguei. $61 / 4$ inches.

Upper parts streaked with buff and blackish; below pale buffy with black markings. These birds are found on the Plains from the Dakotas to Hudson Bay in summer, migrating to Mexico in winter. They resemble the European Skylark in their habit of soaring to a great height while singing. Their song is very melodious, resembling that of the Bobolink. Their nests are depressions in the ground, lined with grasses. Eggs grayIsh, finely specked with purplish gray $(.87 \times .67)$.

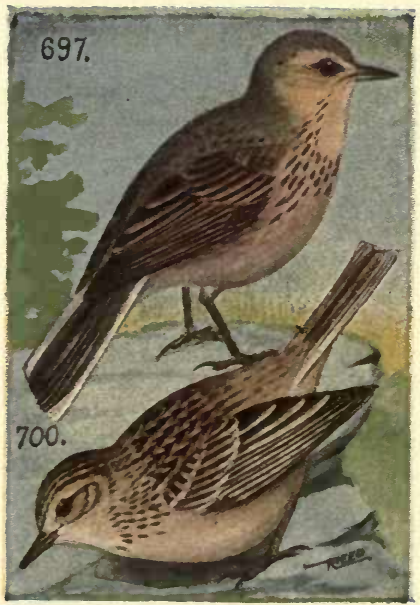

179 


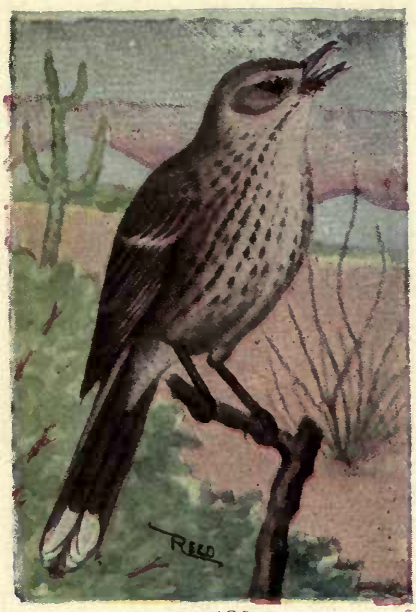

SAGE THRASHER.

702. Orevscoptes montanus. $8 \% \frac{1}{4}$ inches.

This species is often known as the Mountain Mocking. bird because of the brilliance of its song, a very varied performance, long continued and mocking that of many other species. They inhabit sage-brush regions and are partial to the lower portions of the country, although frequently met in open mountains. They are not shy and can readily be located by their voices.

Nest.- In bushes, especially the sage and cactus; a loose structure made of bark-strips, small twigs and coarse grasses, lined with fine rootlets. The three or four eggs have a rich greenish-blue ground, spotted with bright reddish brown $(.95 \times .70)$.

Range.-Sage-brush regions of western United States from the Plains to the Pacific; winters in Mexico and Lower California. 


\section{MOCKINGBIRD.}

703. Mimus polyglottos. $101 / 2$ inches.

General colors, gray and white; bases of primaries and outer tail feathers with white.

This is the great vocalist of the south, and by many is considered to be the most versatile singer in America. It is found in gardens, pastures and open woods. All its habits are similar to our Catbird, and like that species, it is given to imitating the notes of other birds.

Song.-An indescribable medley, sometimes very sweet and pleasing, at others, harsh and unmusical.

Nest.-Usually built in impenetrable thickets or hedges, or again in more open situation in the garden; made of twigs and rootlets, lined with black rootlets; the four or five eggs are bluish green with blotches of reddish brown $(.95 \times .70)$.

Range.-Southern U. S., breeding north to New Jersey (and casually farther) and Ohio; winters in the South Atlantic and Gulf States. 703a. Western Mockingbird (leucopterus) is found. in southwestern U. S., north to Indian Territory and California.

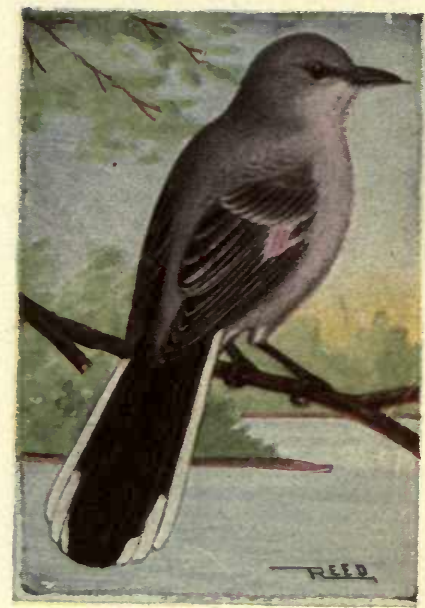




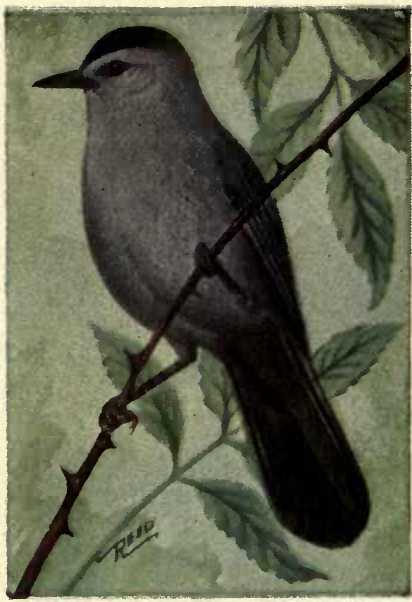

182
CATBIRD.

704. Dumetella carolinensis. 9 inches.

General color dark gray with a black cap and chestnut under tail coverts.

This is one of the most common birds throughout the United States, being found equally abundantly in gardens, swamps and scrubby pastures. They are very persistent songsters and have a large repertoire of notes, as well as being able to imitate those of many other birds. They delight in spending an hour or more at a time, perched in a bush or tree top, singing, and apparently making their song up as they go along, for it is an indescribable medley interspersed with various mews and cat calls.

Song. - A medley like that of the Mockingbird; sometimes pleasing, sometimes not.

Nest.-In hedges or thickets; made of twigs, rootlets and grass, lined with fine black roots; the four eggs are plain greenish blue $(.95 \times .70)$.

Range. -N. A., breeding from the Gulf to New Brunswick and Hudson Bay; rare west of the Rockies; winters from the Gulf States southward. 


\section{BROWN THRASHER.}

705. Toxostoma rufum. $111 / 2$ inches.

Above bright reddish brown; below white with black spots.

Taken as a whole, I think that the song of this Thrasher is the most musical and pleasing of any that I have ever heard. It has a similarity to that of the Catbird, but is rounder, fuller and has none of the grating qualities of the song of that species. They apparently have a song of their own and do not deign to copy that of others. They are one of the most useful and desirable birds that we have.

Song.-A bright and cheerful carol, often long continued, but always clear and sweet; call, a clear whistled "wheuu."

Nest.-Of twigs and rootlets, in hedges, thickets or thorn bushes; the four or five eggs are bluish white with numerous fine dots of reddish brown over the entire surface $(1.08 \times .80)$.

Range.-Eastern N. A., breeding from the Gulf to southern Canada; winters in the southern half of the U. S.

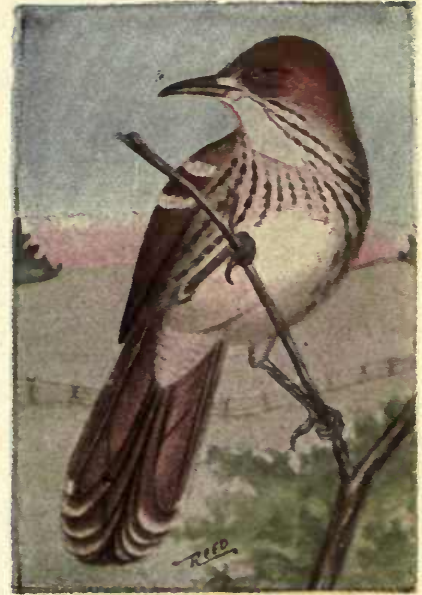

183 


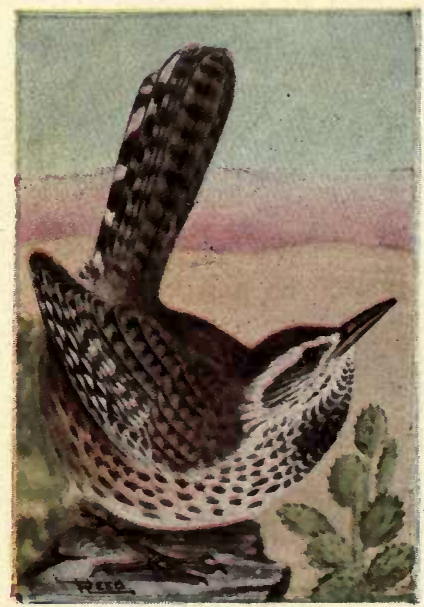

184

\section{CACTUS WREN.}

713. Heleodytes brunneicapillus. $81 \frac{1}{2}$ inches. Cactus groves are the favorite resorts of these large Wrens. Often a bed of cactus not more than thirty feet square will contain the homes of half a dozen pairs of them. Like all the members of the family, they are very sprightly and have violent tempers, scolding anyone or anything that incurs their displeasure.

Nest.-Their nests are placed in cactus or other thorny shrubs; they are very large, purse-shaped affairs with an entrance on the side; they are made of little thorny twigs and grasses woven together, and the interior is warmly lined with feathers. The four or five eggs are creamy white, finely sprinkled with reddish brown $(.95 \times .65)$. Two or three broods are often raised in a season.

Range.-Southwestern border of the United States, ranging from southern Texas to California. 


\section{ROCK WREN.}

715. Salpinctes obsoletus. $53 / 4$ inches.

Upper parts stone color, specked with black; rump brownish; underparts whitish with indistinct streaks on the throat.

A common bird on the dry, rocky foothills of the Rockies and westward. They are well named, for their favorite places are among the rocks, where they are always busily engaged in hunting insects or spiders in the crevices. Owing to their colors and their habits of slinking away behind the rocks they are quite difficult to see, but their sweet song is always heard if any of the birds are in the vicinity.

Song.-Very sweet and varied, almost canary-like, but impossible to describe; call, a harsh grating note.

Nest.-Of sticks, weeds, grasses, etc., concealed in crevices among the rocks; the five or six eggs are white, sparingly specked with reddish brown (.72 $\times .54)$.

Range.-Western U. S. from the western border of the Plains to the Pacific, north to Dakota and British Columbia; winters from southwestern U. S. southward.

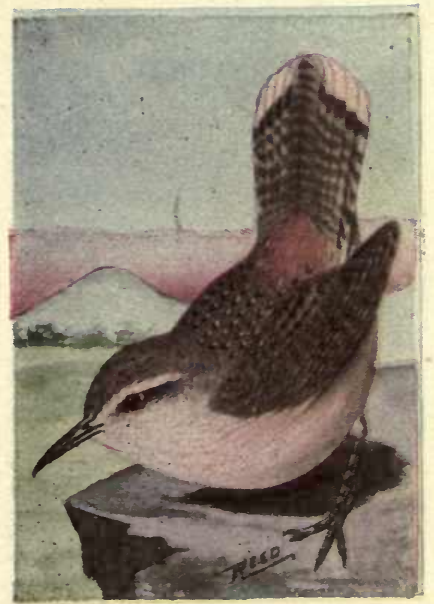

185 


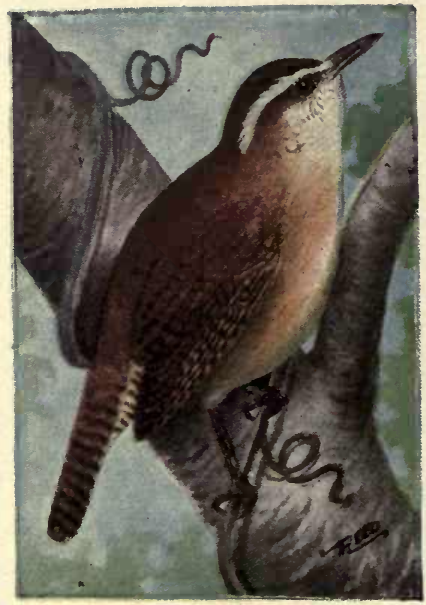

\section{CATOLINA WREN.}

718. Thryothorus ludovicianus. 51/2 inches.

Above rusty brown and below washed with the same, the throat and line over the eye being white.

Like all the Wrens, this one commonly sits or flits about in the brush, with the tail erect over the body; only when singing is it held downward. Their flight is usually only for a short distance, accomplished by rapid wing beats and with a jerking motion of the tail.

Song.-Loud and tinkling, and utterly impossible to describe.

Nest.-In brush heaps, holes in trees, bird boxes or bushes; made of weeds, grass and any trash that they may pick up; eggs, five to seven in number, white, specked with reddish brown $(.74 \times .60)$.

Range.-Eastern U. S., breeding from the Gulf north to Connecticut and Illinois; resident. 718a. Florida Wren (miamensis) is found in southern Florida. $718 \mathrm{~b}$. Lomita Wren (lomitensis), found in southern Texas. 


\section{BEWICK WREN.}

719. Thryomanes bewickii. 5 inches.

Above dark brown; below and line over eye whitish; tail blackish with the outer feathers barred with white.

Like all the Wrens, these seem to be very restless and are continually creeping about in brush heaps or along stone walls, fences or over fallen trees or stumps. They are locally abundant in interior United States, in some sections entirely replacing the House Wren.

Song.-A sweet chant of liquid melodious notes.

Nest.-In any location that happens to take the bird's fancy, such as holes in trees, bird boxes, in barns, sheds, etc.; made of straw, grass and trash; eggs white profusely specked with reddish brown.

Range.-Mississippi Valley and the Plains north to South Dakota; east to the Alleghanies and casually to the South Atlantic States. 719c. Texas Bewick Wren (cryptus) is found from Texas north to Indian Territory.

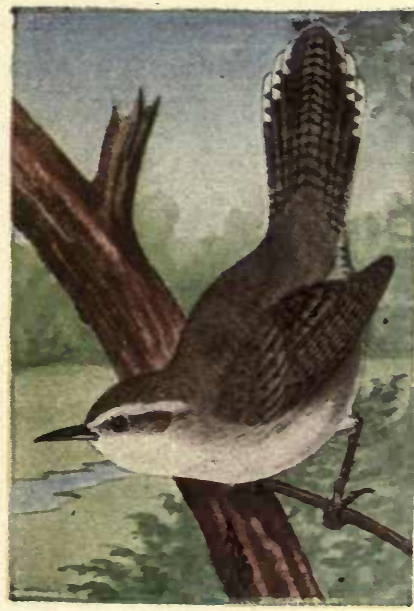




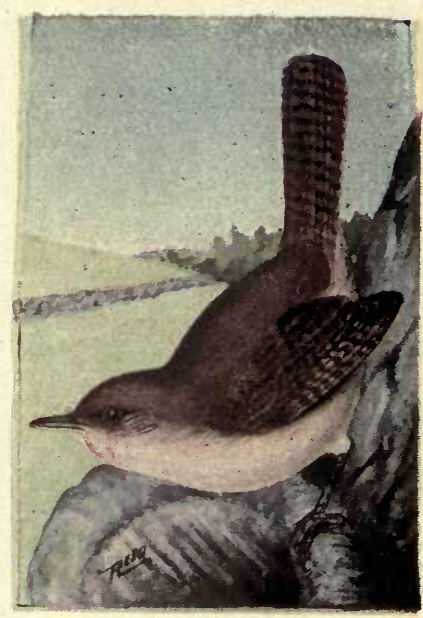

188

\section{HOUSE WREN.}

721. Troglodytes adon. $4 \%$ inches.

Above brownish with tail and wings barred; below dull grayish, barred on the flanks with brown.

These are bold, sociable and confiding birds, seeming to prefer men's society, building their nests in bird boxes that are erected for them, or in the most unexpected situations about buildings. They are one of the most beneficial birds that can be attracted to one's yard, feeding wholly upon insects.

Song.-Loud, clear and bubbling over with enthusiasm.

Nest.-Of grass or weeds, stuffed into any crevice that takes their fancy, frequently in bird boxes and holes in orchard trees; eggs white, so minutely and thickly dotted with pinkish brown as to nearly conceal the ground color $(.64 \times .52)$.

Range.-Eastern N. A., breeding north to Maine and Manitoba; winters along the Gulf coast. 72lb. Western House Wren (aztecus) is found from the Plains to the Pacific coast ranges. 


\section{WINTER WREN.}

722. Nannus hiemalis. 4 inches.

Above bright cinnamon, below paler; șides, wings and tail heavily barred with black.

This is the shortest and most stoutly built Wren that we have. They look very pert with their little stubby tail erect over their back. In most of the-United States we only see them in the winter, and they are associated, in my mind, with brush heaps in woods and gardens. They will hide in a small pile of brush, running from side to side, so that it is almost impossible to make them leave it.

Song.-A rippling flow of melody, not as loud, but more musical than that of the House Wren.

Nest.-In brush heaps, tin cans, hollow stumps or crevices in unoccupied buildings; made of piles of grass, weeds, etc., lined with feathers; eggs white, sparingly specked with reddish brown $(.65 \times .50)$.

Range.-Eastern N. A., breeding from the northern edge of the U. S. northward; winters from its breeding range to the Gulf.

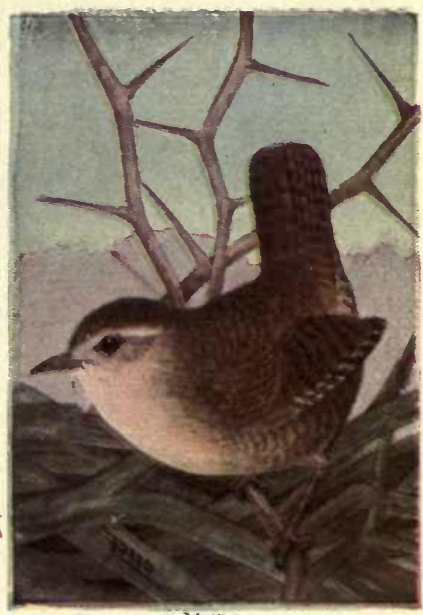

189 


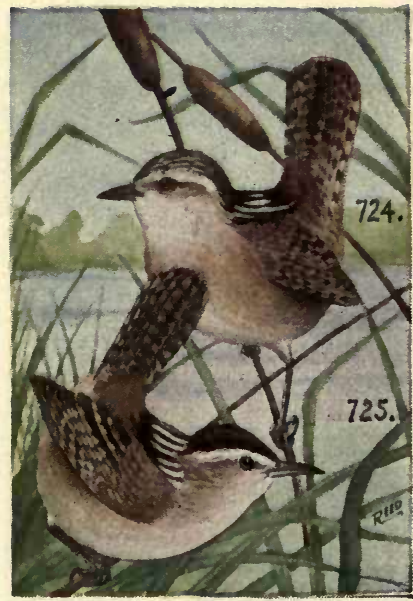

$190^{r}$

\section{SHORT-BILLED MARSH WREN.}

724. Cistothorus stellaris. 51/4 inches.

This species can readily be distinguished from the next, as the whole crown is streaked with black and white, whereas that of the Long-bill is uniformly colored. Both species are marsh birds, at home among the reeds, to which they attach their globular woven nests, with the little entrance in the side. The eggs of this species are pure white. It is found in eastern N. A.: from the Gulf to southern Canada.

\section{LONG-BILLED MARSH WREN.}

725. Telmatodytes palustris. $51 / 4$ inches.

The bill of this species is .5 inch or more in length; that of the last is .4 inch or less. This species is by far the most abundant. Its eggs are so profusely dotted with dark brown as to appear a chocolate color. Breeds from the Gulf to Massachusetts and Manitoba. 


\section{BROWN CREEPER.}

726. Certhia familiaris americana. 51/2 inches. Tail feathers stiffened and pointed; rump rusty. These odd birds are fairly common throughout the Jnited States in winter. They will be found in woods always climbing up tree trunks, carefully investigating every crevice in the bark for larvæ or grubs. When they reach the top of one tree, they drop to the foot of the next and continue the operation. They are very tame, not seeming to comprehend that danger can befall them, for they will allow anyone to approach very closely, so that they have been caught under a hat.

Song.-A very faint trill; call, a weak "tseep," hardly noticeable unless very near them.

Nest.-Of twigs, moss and bark, behind loose bark on dead trees or stumps, usually not high above the ground; eggs white, specked with reddish brown.

Range.-Eastern N. A., breeding from northern New England and Minnesota northward; winters throughout the U.S.

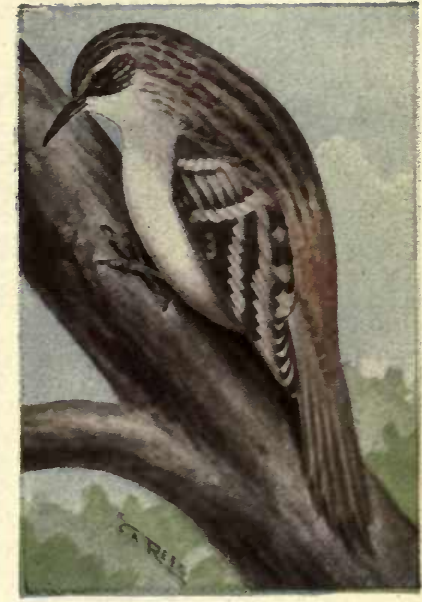

191 


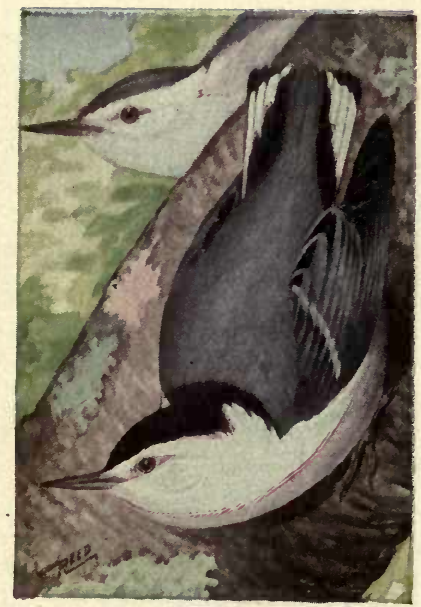

192

\section{WHITE-BREASTED NUTHATCH.}

727. Sitta carolinensis. 6 inches.

Male with the crown bluish black; female with the crown gray; both sexes with chestnut under tail coverts. These birds seem to be the very opposite of the Brown Creepers. Their tails are short and square, and nearly always pointed toward the zenith, for Nuthatches usually clamber among the branches and down the tree trunks, head first.

Note.-A nasal "yank-yank," and a repeated "ya-ya," all on the same tone.

Nest.-In cavities of hollow limbs and trunks of trees at any elevation from the ground; the cavity is filled with leaves and usually lined with feathers; eggs white, spotted with reddish brown $(.75 \times .55)$.

Range.-Eastern United States, breeding from the Gulf to southern Canada; resident in most of its range. $727 \mathrm{~b}$. Florida White-breasted Nuthatch (atkinsi) is slightly smaller; other races are found west of the Rockies. 


\section{RED-BREASTED NU'THATCH.}

728. Sitta canadensis. $41 / 2$ inches.

These birds have the same habits as the larger Nuthatch, but are often found in flocks, while the Whitebreasted are usually in pairs and in the fall accompanied by their young. In the winter we usually find them in coniferous trees, where we can locate them by their nasal calls or by the shower of bark that they pry from the tree in their quest for grubs.

Song.-A nasal "yank-yank," like that of the last, but not so loud, and usually repeated more times.

Nest.-In hollow stumps and limbs, the area about the opening nearly always being coated with fir balsam, for what purpose is not known; the cavity is lined with grasses and feathers; they lay from four to seven white eggs, which are very thickly spotted with reddish brown $(.60 \times .50)$.

Range. - N. A., breeding from the northern parts of the northern tier of states, northward; winters south nearly to the Gulf and southern California.

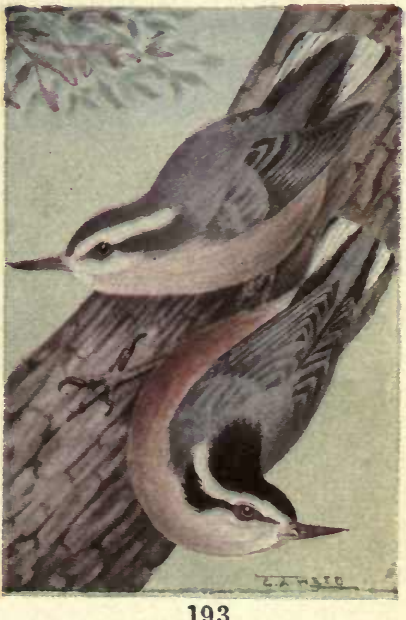




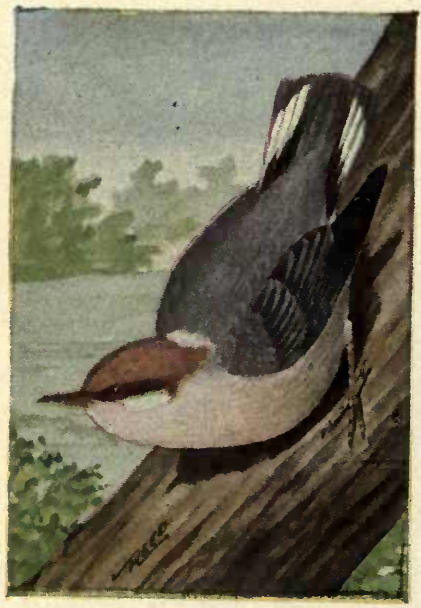

194

\section{BROWN-HEADED NUTHATCH.}

729. Sitta pusilla. $41 / 4$ inches.

Crown brownish with a white patch on the nape.

These diminutive Nuthatches are found in the southern states. Their general habits do not appear to differ from those of other members of the family. They nest very early, commencing to excavate their holes in January and having complete sets of eggs as early as the middle of February.

They usually are found in small flocks and at night they will often be seen flying to the top of a pine where they sleep, all huddled together.

Notes.-A continued twittering "nya-nya."

Nest.-In cavities of dead limbs or stumps, sometimes only a few inches from the ground, and again as high as fifty feet; they lay five or six eggs, white with numerous spots of reddish brown $(.62 \times .49)$.

Range.--South Atlantic and Gulf States, breeding north to Virginia. 


\section{TUFTED TITMOUSE.}

731. Broolophus bicolor. 6 inches.

Head crested, forehead black, flanks brownish. The habits of this large Titmouse are almost identical with those of Chickadees. They swing from the ends of twigs in all manner of positions and creep about trunks, peering in erevices of the bark for insects. They are common in the southern states, breeding from the Gulf to New York and Illinois; they are resident in the southern portion of their range. Their eggs are laid in soft nests of down and feathers in hollow stumps. Their notes are loud, clear whistles.

\section{BLACK-CRESTED TITMOUSE.}

732. Baolophus atricristatus. 6 inches.

Crest black, forehead white, flanks rusty. The habits of this species are just like those of the very similar preceding one. The birds are very tame, especially so during the nesting season, when they will allow themselves to be lifted from the nest by hand. They are found in southern and western Texas.

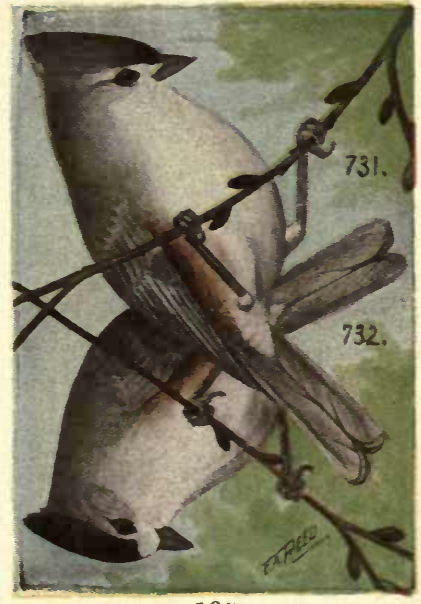

195 


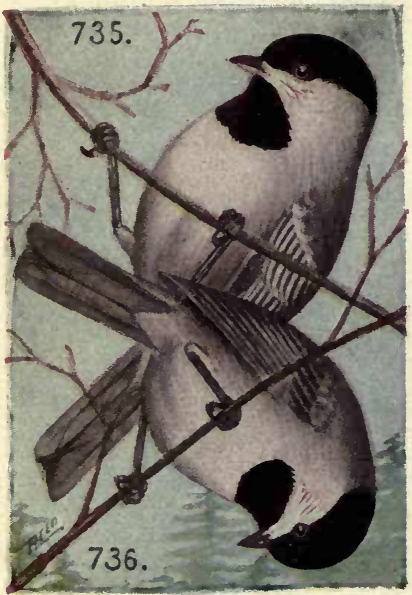

196

\section{BLACK-CAPPED CHICKADEE.}

735. Penthestes atricapillus. 51/4 inches.

The Chickadees are one of the most popular birds that we have, owing to their uniform good nature even in the coldest weather, and their confiding disposition. They are common about farms and even on the outskirts of large cities they will come to feasts prepared for them on the window sill.

Notes.-A clear "phe-be"; a "chick-a-dee-dee-dee" or "dee-dee-dee," and several scolding or chuckling notes.

Nest.-In hollow stumps at any elevation from the ground but usually near the ground, and most often in birch stubs; eggs white, sparingly specked with reddish brown.

Range.-Eastern N. A., breeding in the northern half of the U. S. and northward; resident.

736. Carolina Chickadee (Parus carolinensis) is similar to the last but smaller and with no white edges to the wing feathers; length $4 \frac{1}{2}$ inches; found in south. eastern U. S., breeding north to Virginia and Ohio. 


\section{HUDSONIAN CHICKADEE.}

740. Penthestes hudsonicus. 5 inches.

Crown and back brownish.

The habits of this little northerner are like those of the bird that we know so well; if anything they are even more tame than our bird, especially in the vicinity of lumbermen's camps. 'They are only met with along our northern border or casually farther south; I have seen one individual in company with other Chickadees in Massachusetts.

Song.-Not distinguishable from that of our Chickadee, but uttered more incessantly.

Nest.-In cavities of stumps, trees, posts or telephone poles, the cavity being lined with grass, feathers and fur; the six or seven eggs are white sprinkled with brown $(.60 \times .46)$.

Range.-Resident in Canada and the northern border of the U. S.

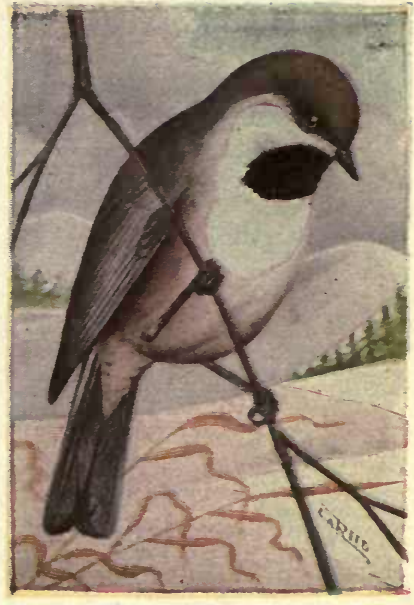

197 


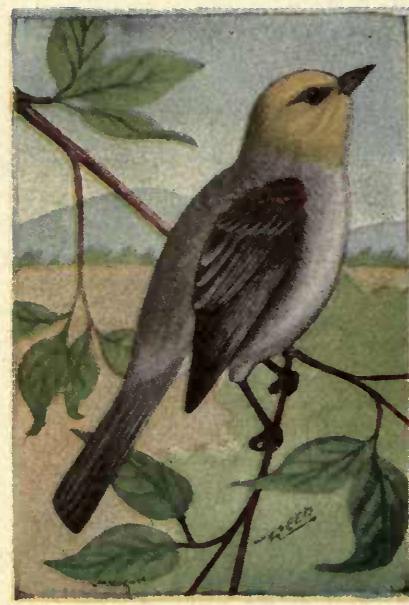

198

\section{VERDIN; YELLOW-HEADED TIT.}

746. Auriparus flaviceps. $41 / 4$ inches. Adult male with the head and throat yellow, usually with some concealed orange-brown on the forehead; lesser wing-coverts reddish brown. The female is colored very similarly, but is much duller. These are among the smallest of N. A. birds; they are even smaller than their length would indicate, for their bodies are slender. The birds are usually found in high dry portions of the country where cacti and thorny bushes predominate.

Nest.-Their nests are remarkable structures for so diminutive birds; flask-shaped, the outside being a mass of thorny twigs and stems interwoven; this is lined with feathers and the entrance is a small circular hole near the top. The eggs are bluish white specked around the large end with reddish brown.

Range.-Mexican border of the United States from southern Texas to Arizona and Lower California. 


\section{GOLDEN-CROWNED KINGIET.}

\section{Regulus satrapa. 4 inches.}

Male with crown orange and yellow, bordered with black; female with yellow crown.

Although very small, these birds are very rugged and endure the severe storm and low temperatures of our northern states apparently with little concern, for they always seem to be happy. They are always busily engaged among the underbrush of side hills and along the banks of brooks, hunting for the scanty fare that awaits them.

Song.-A few weak chips, chirps and trills.

Nest.-A large ball of soft green mosses and feathers, suspended from the small twigs in the tops of coniferous trees; it is neatly hollowed out for the reception of the six to nine eggs that are laid; eggs creamy white, minutely but profusely specked with brown $(.56 \times .44)$.

Range.-N. A., breeding from northern U. S. northward and farther south in mountain ranges; winters throughout the U. S.

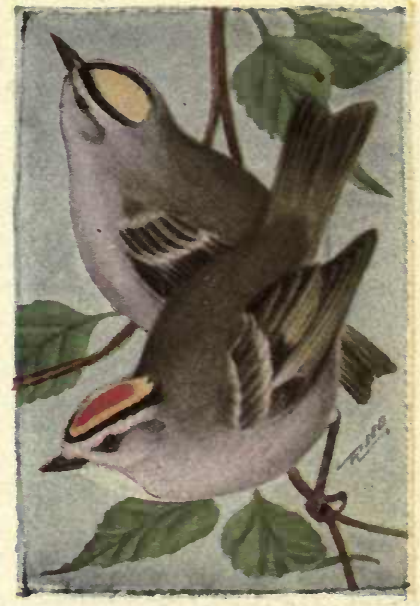




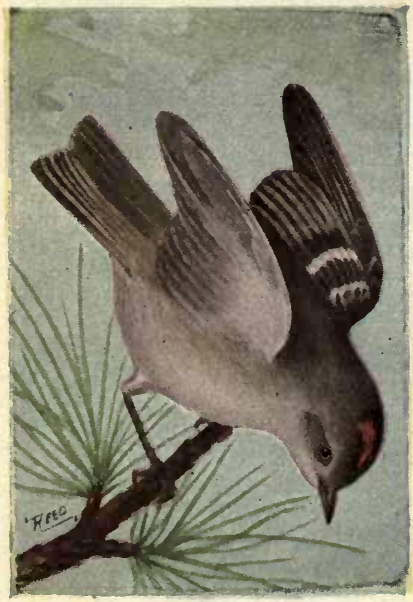

RUBY-CROWNED KINGLET.

749. Regulus calendula. $4 \frac{1}{4}$ inches.

Male with a concealed patch of red on the crown; female with no red.

Like the last, these are chiefly winter visitants in the United States and they do not remain with us in the coldest weather, but pass on to the southern half of our country. They are nearly always met with in pine or other coniferous trees, being very abundant in spring in open pine woods and parks.

Song.-A clear warble, surprisingly loud and varied for so small a bird; call, a grating chatter.

Nest.-A ball of moss, grass and feathers, deeply cupped, like that of the last; partially suspended among the small twigs in the tops of coniferous trees; eggs white, more sparingly marked than those of the last $(.55 \times .43)$.

Range.-N. A., breeding northward from the northern boundary of the U. S. and farther south in mountains; winters in the southern half of the U.S. 


\section{BLUE-GRAY GNATCATCHER.}

751. Polioptila carulea. $41 / 2$ inches.

Forehead black; tail black with white edges and tips to the outer ones.

Their food is chiefly insects, which they are very expert in catching, taking them on the wing with great celerity. Their movements are all very rapid, flitting from one part of a tree to another, but usually among the upper branches. Their nests are among the most beautiful of bird architecture, even surpassing that of the Hummingbird.

Song.-Sweet, but very faint.

Nest.-Situated on horizontal limbs of trees at medium heights; made of plant fibres, woolly substances and cobwebs, adorned with handsome lichens; the walls are very high and thick, the bird sitting so low inside that only her tail is visible; the four or five eggs are bluish white specked with reddish brown $(.56 \mathrm{x} .44)$.

Range.-Eastern U. S., breeding north to New Jersey and Illinois.

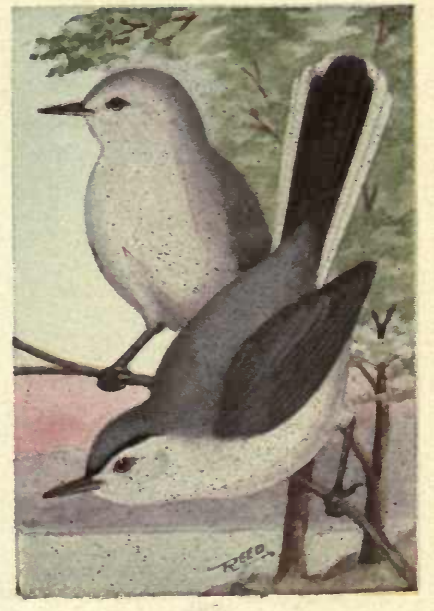




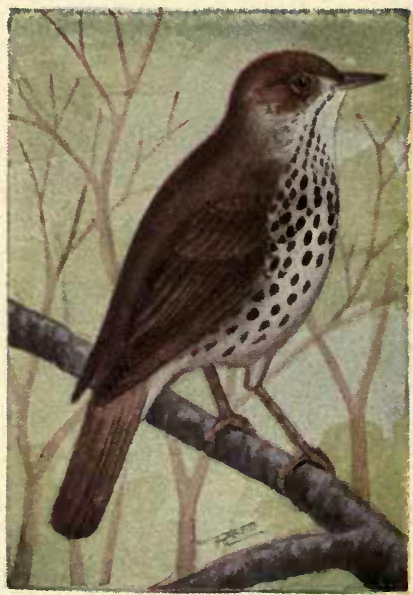

202
WOOD THRUSH.

755. Hylocichla mustelina. 8 inches.

Reddish brown above, brightest on the head; below white heavily spotted with black.

These large Thrushes are locally abundant in swamps and moist woodland. They are one of our best songsters, their tones being very rich and flute-like, and, like most of the Thrushes, their songs are most often heard along toward night.

Song.-Very clear and flute-like, containing many notes of the scale; often two or more birds answer back and forth from different parts of the woods; calls, a sharp "quit, quit" and a liquid "quirt."

Nest.-Either in forks or on horizontal boughs of bushes or trees, usually not more than ten feet from the ground; made of grass, weeds, leaves and some mud; the three or four eggs are bluish green $(1.02 \times .75)$.

Range.-Eastern U. S., breeding from Virginia and Missouri north to Maine, Ontario and Minnesota; winters south of the U.S. 


\section{WILSON THRUSH OR VEERY.}

756. Hylocichla fuscescens. $71 / 2$ inches.

Entire upper parts a uniform reddish brown; below soiled white with a few faint marks on the breast.

This species is more abundant than the last. It is found in swamps and also in dry open woods, they being especially numerous where ferns grow luxuriantly.

Song.-Very peculiar and not nearly as melodious as that of the Wood Thrush, but still attractive; a slightly descending "too-whe-u-whe-u-whe-u"; call, a clear "wheeyou."

Nest.-On the ground among the leaves, on hummocks, or in tangled masses of briars; made of strips of bark and leaves; eggs greenish blue, darker and smaller than those of the Wood Thrush $(.88 \times .65)$.

Range.-Eastern N. A., breeding in the northern half of the United States and southern Canada; winters in Central America. 756a. Willow Thrush (salicicola) is more olive above; it is found in the Rockies and eastward to the Mississippi River.
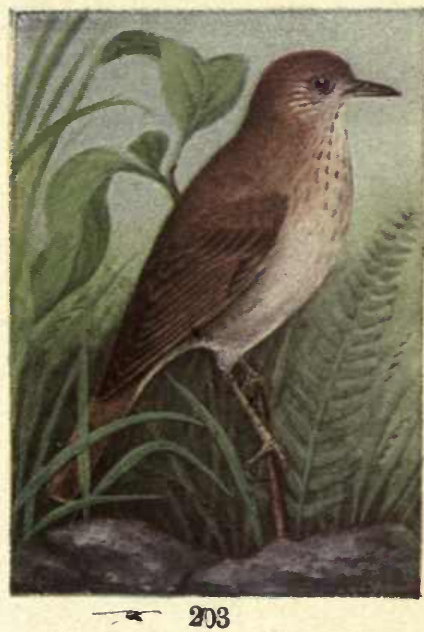


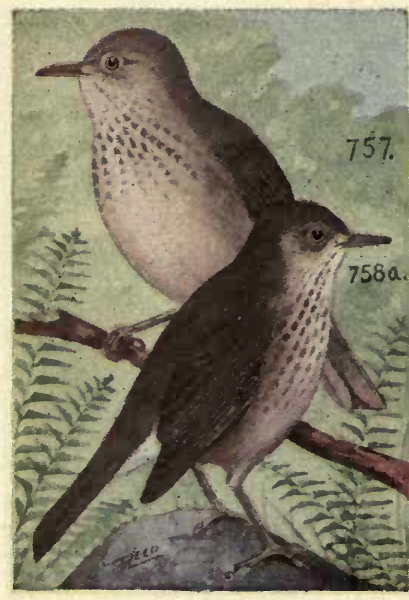

204
GRAY-CHEERED THRUSH.

757. Hylocichla aliciae. $71 / 2$ inches.

Quite similar to the following but with the eye ring white and the sides of head and breast much paler.

Breeds in northern Canada and migrates through the eastern states to Central America. 757a. Bicknell Thrush (bicknelli) is similar to the Gray-cheeked but smaller. It breeds in Nova Scotia.

\section{OLIVE-BACKED THRUSH.}

758a. Hylocichla ustulata swainsonii. $71 / 4$ inches.

Upper parts wholly olive gray, with no brownish tinge; eye ring, sides of head and breast distinctly buff; breast spotted with blackish.

Song.-Quite similar to that of the Veery.

Nest.-Composed of leaves, grass and strips of bark, located in bushes or small trees near the ground; the four eggs are greenish blue spotted with reddish brown $(.90 \times .65)$.

Range.-Eastern N. A., breeding from northern U. S. to New Brunswick and Manitoba. 


\section{FERMIT THRUSH.}

759b. Hylocichla guttata pallasii. 63/4 inches.

Tail reddish brown, much brighter than the back and head; breast quite heavily spotted with black.

During its migrations it rarely sings but in its summer home it is regarded as a remarkable musician. Its song has the sweetness and purity of tone of that of the Wood Thrush, and is, perhaps, more varied, but it is not nearly as powerful, and has a ventriloquial effect. I watched one that was perched on a dead stump, about twenty feet from me, for several minutes with a pair of glasses before I could make sure that he was the author of the song I heard, for it sounded as though coming from across the next field.

Nest.-Similar to that of the Wilson Thrush and like that, placed on the ground or very near it; the eggs are plain greenish blue $(.85 \times .65)$.

Range.-Breeds from northern U. S. northwards, and farther south in mountains; winters in the Gulf States.

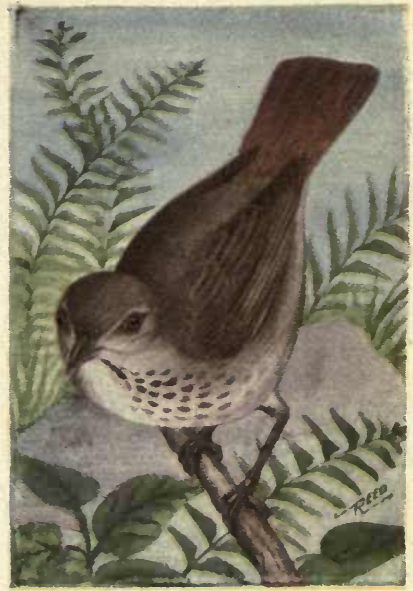

205 


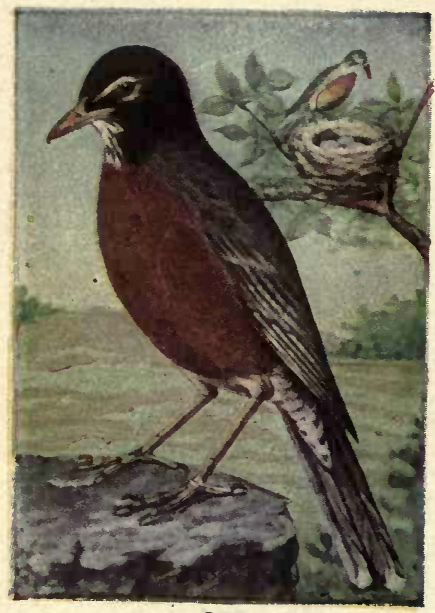

206

\section{AMERICAN ROBIN.}

761. Planesticus migratorius. 10 inches.

Male with a black head and bright reddish-brown breast; female with a gray head and much paler breast; young intermediate between the two and with a reddishbrown breast spotted with black.

These well-known birds are very abundant in the northern half of the United States, being found most commonly about farms and dwellings in the country, and also in cities if they are not persecuted too severely by English Sparrows.

Song.-A loud cheery carol, "cheerily-cheerup, cheerily-cheerup," often long continued.

Nest.-A coarse but substantial structure of mud and grass, placed on horizontal boughs or in forks at any height, or in any odd place about dwellings; the four or five eggs are bluish green (1.15 x .80).

Range.-Eastern N. A., breeding from the middle of the U. S. northward; winters throughout the U. S. 761b. Southern Robin (achrustera) is a paler form found in the Carolinas and Georgia. 


\section{GREENLAND WHEATEAR.}

765a. Saxicola conanthe leucorrhoa. 6 inches. The Wheatear is a European bird, but this sub-species is found in Greenland and occasionally in Labrador.

Their habits are about the same as those of the Bluebird. They feed upon insects, larvæ, fruits, berries and some seeds. They are essentially ground birds and are usually found in rocky country.

Nest.-Their nests are made of grasses, hair or any rubbish obtainable, and are hidden in the innermost recesses of erevices among rocks, in deserted Bank Swallow nests or even in rabbit burrows.

The four to six eggs are pale greenish blue, a little brighter in shade than those of the Bluebird. They measure $.94 \times .60$.

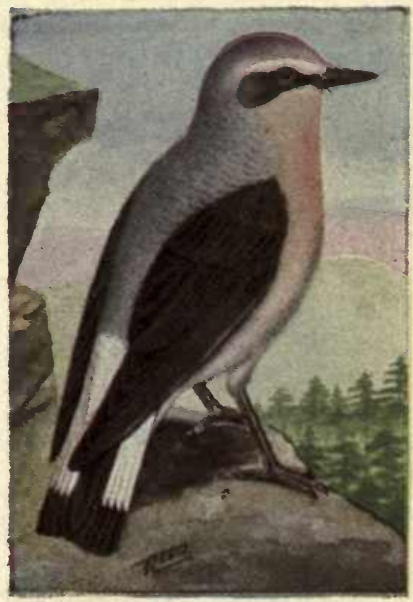




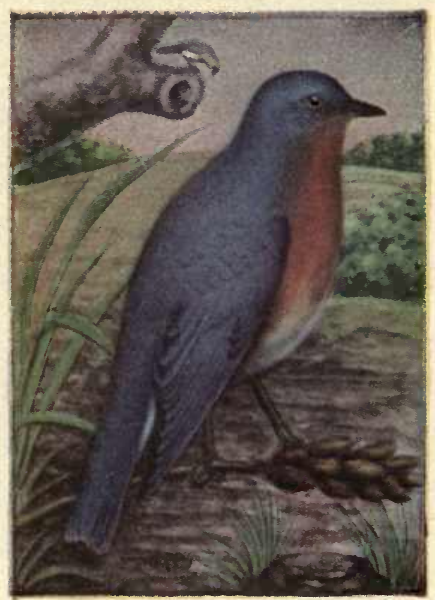

\section{BLUEBIRD.}

766. Sialia sialis. 7 inches.

These beautiful, gentle and well-known birds spend the winter in the southern parts of the United States and north to the snow line; some more hardy than the rest are found throughout the winter in southern New England.

Call.-A short sweet warble; song, a continued warbling.

Nest.-In holes in trees, particularly in orchards, in bird boxes or crannies about the buildings. The bottom of the cavity is lined with grasses for the reception of the four or five pale bluish eggs, which measure $.84 \times .62$.

Range.-Eastern United States, breeding from the Gulf to New Brunswick and Manitoba; winters chiefly in the southern parts of the United States. 766a. Azure Bluebird (azurea) is found in the mountains of eastern Mexico and north casually to southern Arizona. It is paler both above and below than our eastern bird. 


\section{FIEL.D KEY FOR IDENTIFICATION OF EASTERN LAND BIRDS BY CONSPICUOUS MARKINGS}

We hare added this key at the request of many of our readers for a color scheme for identification. It includes all the birds that have markings of sufficient prominence to be readily noticed in the field.

\section{BIRDS WITH RED OR ORANGE MARKINGS.}

Scarlet body; black wings and tail ; 71/2 in.-SCARLET TANAGER. Red; darker above; crested; black face; 9 in.-CARDINAL.

Rosy-red; wings and tail slightly darker; $71 \frac{1}{2}$ in.-SUMMER TANAGER.

Rosy-red; white wing bars; crossed bill; 6 in.-WHITE-WINGED CROSSBILL. Rosy-red; gray back, wings and tail ; stout bill ; 81/2 in.-PINE GROSBEAK. Brick-red; wings and tail darker; crossed bill; 6 in.-CROSSBILL. Purplish-red, streaked with darker; dark wings and tail.-PURPLE FINCH. Red below; blue head; yellow back; 51/2 in.-PAINTED BUNTING. Red patch on crown (concealed) ; greenish back; 41/2 in.-KINGLET. Red cap; black chin ; rosy breast; streaked; 51/4 in.-REDPOLL.

Pink breast and under wings; black head and back; 8 in.-ROSE-BREASTED GROSBEAK.

Ruby throat; metallic green back; tiny birds-HUMMINGBIRD. 
Orange-red under wings and patch on crown; long forked tail.-SCISSOR-TAILED FLYCATCHER.

Orange; black head, wings and tail (marked with yellow)-BALTIMORE ORIOLE. Orange breast, crown patch and above eye; black and white back, wings and tail -BLACKBURNIAN WARBLER.

Orange crown patch, edged with black; green back; 4 in.--KINGLET.

Orange on sides, wings and tail; black above ; $5 \frac{1}{2}$ in.-REDSTART.

Orange-brown crown edged with black; green back; spotted breast-OVENBIRD.

\section{BIRDS PROMINENTLY MARKED WITH BLUE.}

Blue, shading to purplish on head; $5 \frac{1}{2}$ in.-INDIGO BUNTING. Blue; chestnut shoulders; black face; 7 in.-BLUE GROSBEAK.

Blue above; brownish breast; 7 in.-BLUEBIRD.

Blue above; black collar, bars on wings and tail (also white)-BLUE JAY.

Pale blue above and streaks below; white on wings and tail-CERULEAN WARBLER.

Dark blue above; black throat and sides; white on wing-BLACK-THROATED BLUE WARBLER.

Light blue head and back; brown breast; $5 \frac{1}{2}$ in.-LAZULI BUNTING. 


\section{BIRDS WITH YELLOW AS PROMINENT COLOR.}

Yellow below; green back; black mask-MARYLAND YELLOWTHROAT.

Yellow below; gray head and breast; 51/2 in.-MOURNING WARBIER.

Yellow below; gray head and breast; white eye ring-CONNECTICUT WAR. BLER.

Yellow below; black crown and ears; yellow over eye-KENTUCKY WARBLER.

Yellow below; green back; brown spots on back; black stripes on side-PRAIRIE WARBLER.

Yellow below; green back; brown crown and streaks on side; white on tailPALM WARBLER.

Yellow below; green back; yellow crown; brown stripes on sides-YELLOW WARBI.ER.

Yellow below; green back; brown ear patch and streaks on sides-CAPE MAY WARBLER.

Yellow below; green back; brown patch on crown; head gray above-NASHVILLE WARBLER.

Yellow below; green back; orange-yellow head; white on tail-PROTHONOTARY WARBLER. 
Yellow forehead, ears and below; green back; cap and throat black--HOODED WARBLER.

Yellow breast; gray back; black spotted necklace-CANADIAN WARBLER.

Yellow breast; green back; gray head; white over eye-YELLOW-BREASTED CHAT.

Yellow breast; gray back; black through eye and down sides-YELLOWTHROATED WARBLER.

Yellow breast; yellowish patch on back; brown on throat-PARULA WARBLER.

Yellow breast; green above; black throat and down sides-BLACK-THROATED

GREEN WARBLER.

Yellow breast with black crescent; streaked above; 11 in.-MEADOWLARK.

Yellow above and below; black cap, wings and tail-GOLDFINCH.

Yellow head; black body; white patch on wing-YELLOW-HEADED BLACKBIRD.

Yellow head; gray body; brown on shoulders; $41 / 2$ in.-VERDIN.

Yellow crown; chestnut on sides; streaked above-CHESTNUT-SIDED WARBLER.

Yellow below and on rump; black back and spots on breast-MAGNOLIA WARBLER.

Yellow patch on crown, rump and side; streaked with gray above-MYRTLE WARBLER. 


\section{BIRDS WITH BROWN MARKINGS MOST PROMINENT.}

Small brown birds ( 4 to 6 in.) with barred wings and tail-WRENS. Uniform brown above, gray below; long broad tails-CUCKOOS. Bright reddish brown above; spotted breast; 111/2 in.-BROWN THRASHER. Brown body; black head, wings and tail; 71/2 in.-ORCHARD ORIOLE. Reddish brown breast; slate back; dark head; 10 in.-ROBIN. Dull brown back; grayish, more or less spotted breasts-THRUSHES. Rrown belly; black crown and stripe through eye; gray back-NUTHATCH. Streaked brown and white; curved bill; climbs up trees-BROWN CREEPER. Brownish gray; crested; yellow tip to tail; black through eye-WAXWING. Brown crown, throat and streaks on sides; black mask-BAY-BREASTED WARBLER.

Brown sides; black head, throat and back; white on wings and tail-TOWHEE. Brown rump and tail; gray back; streaked above and below-FOX SPARROW. Brown shoulder, yellow breast patch; black on throat-DICKCISSEL. Brown shoulder; streaked above; white outer tail feathers-VESPER SPARROW. Brown shoulder; black cap and patch on breast-McCOWN LONGSPUR. Brown nape; black breast and cap; light throat-CHESTNUT-COLLARED LONGSPUR. 


\section{SHARPLY DEFINED BLACK AND WHITE MARKINGS.}

Black crown and throat; gray back; 5 in,-CHICKADEE.

Black and white streaked bird; black crown; 5 in.-BLACK POLL WARBLER. Black and white streaked bird; striped crown-BLACK AND WHITE WARBLER. Slate head, breast and back; white below and outer tail feathers-JUNCO.

White throat; gray breast; crown striped black and white-WHITE-THROATEI) SPARROW.

Large white crown patch edged with black; light below-WHITE-CROWNED SPARROW.

Black body; yellowish nape; white rump and on wings-BOBOLINK.

Black crown; gray back; climbs down trees-WHITE-BREASTED NUTHATCH. Dull gray birds with no markings may be FLYCATCHERS.

Dull brownish, streaked birds are probably species of SPARROWS.

Plain greenish backs and dull white underparts denote VIREOS.

Glossy blackbirds are GRACKLES or CROWS; if with red shoulders. REDWINGED BLACKBIRD; with dull brown head, COWBIRD. 


\section{CLASSIFIED TABLE OF EASTERN LAND BIRDS.}

Showing Divisions into Orders, Families and Genera, as Adopted by the American Ornithologists' Union.

ORDER PSITTACI. Parrots, Macaws, etc. Family PSITTACIDA. Genus

CONUROPSIS.

Carolina Paroquet.

ORDER COCCYGES. Cuckoos, Kingfishers, etc. Family CUCULIDA. Genus CROTOPHAGA. GEOCOCCYX. COCCYZUS.

Family ALCEDINIDÆ. Genus

CERYLE.

ORDER PICl. Woodpeckers.

Family PICIDAE. Genus

CAMPEPHILUS.

DRYOBATES.

PICOIDES.

SPHYRAPICUS. PHILEOTOMUS. MELANERPES.

Anis.

Road-runner. Cuckoos.

Kingfishers.

Ivory-billed Woodpecker. Hairy to Texan Woodpecker. Three-toed Woodpeckers. Sapsuckers. Pileated Woodpeckers. Red-headed Woodpeckers. 

COLAPTES. Flickers.

ORDER MACROCHIRES. Goatsuckers, Swifts, Hummingbirds, etc.

Family CAPRIMULGIDE. Genus

ANTROSTOMUS.

PHAL ENOPTILUS

NYCTIDROMUS.

CHORDEILES.

Family MICROPODIDA. Genus

CHATURA. ERONAUTES.

Family TROCHILID TROCHILUS.

ORDER PASSERES. Perching Birds.

Family TYRANNIDA. Genus

MUSCIVORA.

TYRANNUS.

PITANGUS.

MYIARCHUS.

SAYORNIS.

Whip-poor-will. Poorwill.

Paraque.

Nighthawks.

Chimney Swift. White-throated Swift.

Ruby-thr. Hummer.

Scissor-tail Flycatcher. Kingbirds. Derby Flycatchers. Crested Flycatchers. Phoebes. 
Family TYRANNIDAE. Gerus

NUTTALLORNIS.

MYIOCHANES.

EMPIDONAX.

PYROCEPHALUS.

Family ALAUDIDA. Genus

OTOCORIS.

Family CORVIDAs. Genus

PICA.

CYANOCITTA.

APHLECOMA.

XANTHOURA.

PERISOREUS.

CORVUS.

NUCIFRAGA.

Family STURNIDA. Genus

STURNUS.

Family ICTERIDA. Genus

DOLICHONYX.

MOLOTHRUS.

XANTHOCEPHALUS.
Olive-sided Flycatchers.

Pewees.

Least Flycatchers.

Vermilion Flycatchers.

Horned Larks.

Magpie.

Blue Jays.

Non-crested Jays.

Green Jay.

Canada Jay.

Crows and Ravens.

Clarke Nutcracker.

Starling.

Bobolink.

Cowbirds.

Yellow-head Blackbird. 
Family ICTERIDÆ. Genus

AGELAIUS. STURNELLA.

ICTERUS.

SCOLECOPHAGUS. QUISCALUS.

Family FRINGILLID A. Genus HESPERIPHONA. PINICOLA. CARPODACUS. LOXIA. LEUCOSTICTE. ACANTHIS. ASTRAGALINUS. SPINUS. PLECTROPHENAX. CALCARIUS. RHYNCOPHANES. POCECETES. PASSER. PASSERCULUS.
Red-winged Blackbirds. Meadowlarks.

Orioles. Rusty Blackbirds. Grackles.

Evening Grosbeak. Pine Grosbeaks. Purple Finches. Crossbills. Ieucostictes. Redpolls. Goldfinches. Pine Siskin. Snowflakes.

Longspurs. McCown Longspurs. Vesper Sparrow. English Sparrow. neswich Sparrow. 
Family FRINGILLIDEE. Genus

COTURNICULUS. AMMODRAMUS. CHONDESTES. ZONOTRICHIA. SPIZELLA. JUNCO.

AMPHISPIZA. PEUCAA. MELOSPIZA. PASSERELLA. PIPILO. OREOSPIZA. CARDINALIS. PYRRHULOXIA. ZAMELODIA. GUIRACA. PASSERINA. SPOROPHILA. SPIZA

CALAMOSPIZA.
Grasshopper, Leconte. Sharp-tail Seaside. Lark Sparrow. Harris and Crowned Spar. Chippy, Tree, Field. Jurcos. Black-throated, Bell. Pine-wood Sparrow. Song, Swamp Sparrow. Fox Sparrow. Towhees. Green-tailed Towhee. Cardinal. Pyrrhuloxia. Rose-breast Grosbeak. Blue Grosbeak. Buntings. Seed-eater. Dickcissel. Lark Bunting. 
Family TANAGRIDA. Genus

PIRANGA.

Family HIRUNDINIDA. Genus

PROGNE.

PETROCHELIDON.

HIRUNDO.

IRIDOPROCNE.

RIPARIA.

STELGIDOPTERYX

Family BOMBYCILLIDA. Genus BOMBYCILLA.

Family LANIIDE. Genus

LANIUS.

Family VIREONIDE. Genus

VIREOSYLVA.

LANIVIREO.

VIREO.

Family MNIOTILTIDA. Genus

MNIOTILTA.

PROTONOTARIA.

HELINAIA.
Tanagers.

Purple Martin.

Cliff Swallow.

Barn Swallow.

Tree S*allow.

Bank Swallow.

Rough-wing. Swallow.

Waxwings.

Shrikes.

Red-eye., Warbling Vireo.

Yell.-thr.. I: c-head.

White-eye Vireo.

Black and White Warbler. Prothollotary.

Swainson Warbler. 
HELMITHEROS. HELMINTHOPHILA. COMPSOTHLYPIS. DENDROICA. SEIURUS. OPORORNIS. GEO'THLYPIS. ICTERIA. WILSONIA. SETOPHAGA.

Family MOTACIILIDA. Genus ANTHUS.

Family TROGLODYTIDA. Genus

ORCSCOPTES. MIMUS.

DUMATELLA. TOXOSTOMA. HELEODYTES. SALPINCTES. THRYOTHORUS.
Worm-eating Warbler. Bachman to Tennessee. Parula Warbler.

Cape May to Palm Warbler. Oven-bird, Water-Thrush.

Ky., Conn., and Mourning. Yellow-throats.

Chat.

Hooded to Canadian. Redstarts.

Pipits.

Sage Thrasher. Mockingbird.

Catbird.

Thrashers.

Cactus Wren.

Rock Wren.

Carolina Wren. 
Family TROGLODYTIDÆ. Genus

THRYOMANES.

TROGLODYTES.

NANNUS.

CISTOTHORUS.

TELMATODYTES.

Family CERTHIDÆ. Genus

CERTHIA.

Family PARIDÆ. Genus

SITTA.

BAOLOPHUS.

PENTHESTES.

AURIPARUS.

Family SYLLVIIDA. Genus

REGULUS.

POLIOPTILA.

Family TURDIDA. Genus

HYLOCICHLA. PLANESTICUS. SAXICOLA. SIALIA.

Bewick Wren.

House Wren.

Winter Wren.

Short-bill Marsh Wren.

Long-bill Marsh Wren.

Brown Creeper.

Nuthatches.

Titmice.

Chickadees.

Verdin.

Kinglets.

Gnatcatchers.

Thrushes.

Robins.

Wheatear.

Bluebird. 



\section{IN DEX}

Anl, Grooved-billed ............. 18

Blackbird, Brewer .............. 71

Blackbird, Red-winged ........... 65

Blackbird, Florida ............. 65

Blackbird, Rusty ............. 71

Blackbird, Yellow-headed ............ 64

Bluebird .................... 208

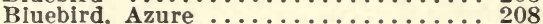

Bunting, Black-throated ........... 122

Bunting, Indigo ............. 117

Bunting, Lark ............... 123

Bunting, Lazuli ............. 118

Bunting, Varied ............... 119

Bunting, Painted ................ 120

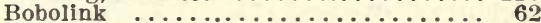

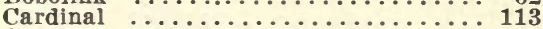

Catbird .................. 182

Chat, Yellow-breasted $\ldots \ldots \ldots \ldots \ldots .174$

Chebec .................. 51

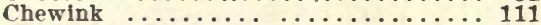

Chickadee, Black-capped .......... 196

Chickadee, Carolina ............. 196

Chickadee, Hudsonian ............ 197

Chuckwill's Widow ............. 34

Cowbird ....................

Creeper, Brown ................ 191
Crossbill, American ........... 77

Crossbill, Whitewinged .......... 76

Crow, American ............. 59

Crow, Clarke ................ 60

Crow, Fish ............... 59

Crow, Florida $\ldots \ldots \ldots \ldots \ldots \ldots \ldots \ldots . .59$

Cuckoo, Black-billed ............. 20

Cuckoo, Mangrove '.............. 19

Cuckoo, Yellow-billed ............. 19

Dickcissel ................. 122

Finch, Purple ............... 75

Flicker ................. 32

Flicker, Red-shafted $\ldots \ldots \ldots \ldots \ldots \ldots 3_{33}$

Flycatcher, Acadian ........... 50

Flycatcher, Crested ............ 46

Flycatcher, Derby ............. 45

Flycatcher, Green-crested ........ 50

Flycatcher, Least .............. 5i

Fiycatcher, Olive-sided .......... 48

Flycatcher, Scissor-talled ......... 41

Flycatcher, Vermilion ........... 52

Flycatcher, Yellow-bellied ....... 50

Gnatcatcher, Blue-gray ...........201

Goldfinch, American ........... 80

Goldfinch, Arkansas ............. 81

Grackle, Boat-tailed ............ 72 
Grackle, Bronzed ............. 72

Grackle, Florida ............ 72

Grackle, Great-tailed ........... 72

Grackle, Purple ............. 72

Grosbeak, Blue ............... 116

Grosbeak, Western ............ 116

Grosbeak, Evening ........... 73

Grosbeak, Pine ............. 74

Grosbeak, Rose-breasted .......... 115

Hummingbird, Ruby-throated ....... 40

Jay, Blue ............... 55

Jay, Blue Florida ............ 55

Jay, Canada ................ 58

Jay, Florida ............... 56

Jay, Green ............... 57

Jay, Labrador .............. 58

Junco, Carolina ................. 104

Junco, Slate-colored .............. 104

Junco, White-winged ........... 103

Kingbird ................... 42

Kingbird, Arkansas ............ 44

Kingfisher, Belted ............... 21

Kingbird, Gray ............... 43

Kingfisher, Texan ............ 22

Kinglet, Golden-crowned $\ldots \ldots \ldots \ldots \ldots .199$

Kinglet, Ruby-crowned .........200

Lark Horned

Lark, Horned Desert $\ldots \ldots \ldots \ldots \ldots \ldots .53$
Lark, Horned Hoyt ........... 5

Lark, Horned Prairie ........... 53

Leucosticte, Gray-crowned ....... 78

Longspur, Chestnut-collared ....... 86

Longspur, Lapland ............ 84

Longspur, McCown ............ 87

Longspur, Smith ............ 85

Magpie, American ........... 54

Martin, Purple .............. 126

Meadowlark .............. 66

Meadowlark, Florida ......... 66

Meadowlark, Western ......... 66

Mockingbird $\ldots \ldots \ldots \ldots \ldots \ldots \ldots \ldots 181$

Nighthawk .............. 37

Nighthawk, Florida ........... 37

Nighthawk, Texan $\ldots \ldots \ldots \ldots \ldots \ldots . . \ldots 37$

Nighthawk, Western .......... 37

Nonpareil .................. 120

Nuthatch, Brown-headed ......... 194

Nuthatch, Red-breasted ........... 193

Nuthatch, White-breasted ......... 192

Nuthatch, Florida White ......... 192

Oriole, Audubon ............. 67

Oriole, Baltimore ............ 70

Oriole, Hooded ................ 68

Oriole. Orchard ............ 69

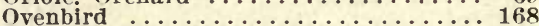

Paraque, Merrill ............. 36 
Pyrrhuloxia

114

Pewee, wood ................... 49

Phoebe .................. 47

Pipit, Amerlcan ............ 179

Pipit, Sprague .............. 179

Poor-will $\ldots \ldots \ldots \ldots \ldots \ldots \ldots \ldots \ldots . \ldots \ldots$

Raven, Northern ........... 59

Raven, White-necked .......... 59

Redpoll .................. 79

Redpoll, Greater ............. 79

Redpoll, Greenland ........... 79

Redpoli, Hoary .............. 79

Redpoll, Holboell ............. 79

Redstart. American ............. 178

Road-runner ................ 18

Robin ................. 206

Robin, southern .............. 206

Sapsucker, Ycllow-bellied ......... 28

Seedeater, Sharp ................ 134

Shrike, Loggerhead ............. 134

Shrike, Northern ............... 133

Shrike, White-rumped .......... 134

Siskin, Pine ............... 82

Snowflake .................. 83

Sparrow, Bachman ............ 106

Sparrow, Baird ............... 91

Sparrow, Black-throated .......... 105
Sparrow, Chipping ............. 109

Sparrow, Clay-colored ............ 101

Sparrow, English .............. 88

sparrow, Field .............. 102

Sparrow, Field Western ......... 102

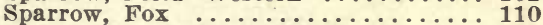

Sparrow, Grasshopper $\ldots \ldots \ldots \ldots \ldots .91$

Sparrow, Harris .............. 96

Sparrow, Henslow ............ 92

Sparrow, Henslow Western ........ 92

Sparrow, Ipswich $\ldots \ldots \ldots \ldots \ldots \ldots \ldots .90$

Sparrow, Lark .............. 95

Sparrow, Lark Western ........... 95

Sparrow, Leconte ............. 92

Sparrow, Lincoln .............. 108

Sparrow, Pine-woods ............ 106

Sparrow, Savanna ............ 90

Sparrow, Seaside ............. 94

Sparrow, Seaside Dusky ......... 94

Sparrow, Sharp-tailed ............ 93

Sparrow, Sharp-tailed Acadian...... 93

Sparrow, Sharp-tailed Nelson........ 93

Sparrow, Song ............... 107

Sparrow, Song Dakota ........... 107

Sparrow, Swamp .............. 109

Sparrow, Tree $\ldots \ldots \ldots \ldots \ldots \ldots \ldots \ldots \ldots 99$

Sparrow, Tree Western .......... 99

Sparrow, Vesper ............. 89 
Sparrow, White-crowned ......... 97

Sparrow, White-throated ................ 98

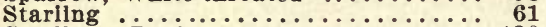

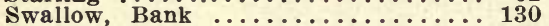

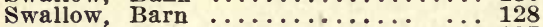

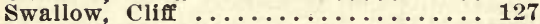

Swallow, Rough-winged .............. 130

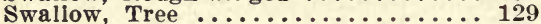

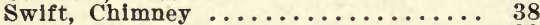

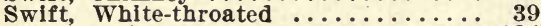

Tanager, Scarlet .............. 124

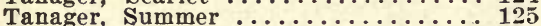

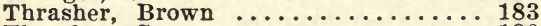

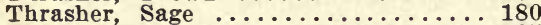

Thrush, Bicknell ................ 205

Thrush, Gray-cheeked ............ 204

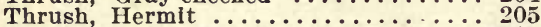

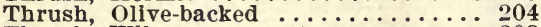

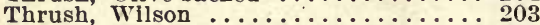

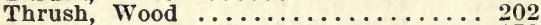

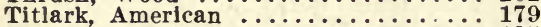

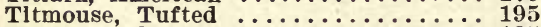

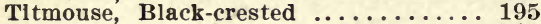

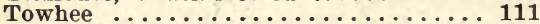

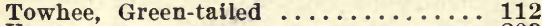

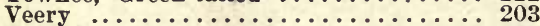

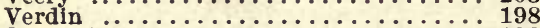

Vireo, Blue-headed ................. 138
Vireo, Black-capped ............. 139

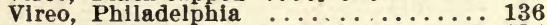

Vireo, Red-eyed ................ 135

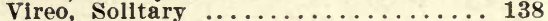

Vireo, Solitary Mountain .......... 138

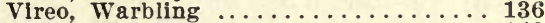

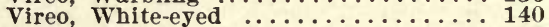

Vireo, Yellow-throated ........... 137

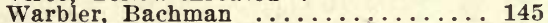

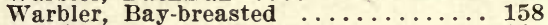

Warbler, Black and White.......... 141

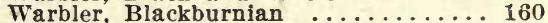

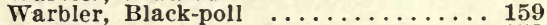

Warbler, Black-throated Blue ....... 153

Warbler, Black-throated Green ...... 163

Warbler, Blue-winged ............ 146

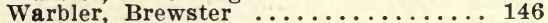

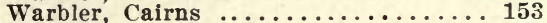

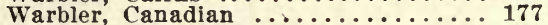

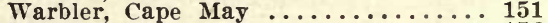

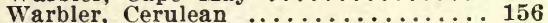

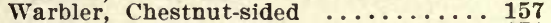

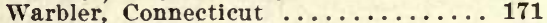

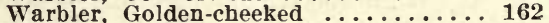

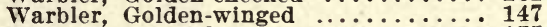

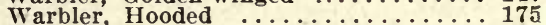

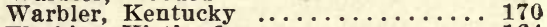

Warbler, Kirtland ............... 164 
Warbler, Lawrence ........... 147

Warbler, Magnolla ................ 155

Warbler, Mourning ............ 172

Warbler, Myrtle ............. 154

Warbler, Nashville ............. 148

Warbler, Orange-crowned ........ 148

Warbler, Palm ................ 166

Warbler, Palm Yellow .......... 166

Warbler, Parula ............. 150

Warbler, Parula Northern ........ 150

Warbler, Pine ..................................

Warbler, Prairie ............. 167

Warbler, Prothonotary .......... 142

Warbler, Sennett ............... 150

Warbler, Swainson ............ 143

Warbler, Sycamore ............. 161

Warbler, Tennessee ............ 149

Warbler, Wilson ............. 176

Warbler, Worm-eating .......... 144

Warbler, Yellow .............. 152

Warbler, Yellow-throated ......... 161

Water Thrush ............... 169

Water Thrush, Louisiana ......... 169

Waxwing, Bohemian ............ 131

Waxwing, Cedar ............... 132

Wheatear, Greenland ........... 207

Whip-poor-will ............... 35

Woodpecker, American Three-toed... 27
Woodpecker, Arctlc Three-toed..... 27

Woodpecker, Downy $\ldots \ldots \ldots \ldots \ldots \ldots .25$

Woodpecker, Downy Northern ...... 25

Woodpecker, Downy Southern ...... 25

Woodpecker, Golden-winged ....... 32

Woodpecker, Hairy ............ 24

Woodpecker, Hairy Northern $\ldots \ldots \ldots .24$

Woodpecker, Hairy Southern ........ 24

Woodpecker, Ivory-billed ............ 23

Woodpecker, Plleated ............ 29

Woodpecker, Pileated Northern ..... 29

Woodpecker, Red-bellied ......... 31

Woodpecker, Red-cockaded ......... 26

Woodpecker, Red-headed ........... 30

Woodpecker, Texan '............. 26

Wren, Bewick .............. 187

Wren, Cactus .................... 184

Wren, Carolina ............. 186

Wren, House .................. 188

Wren, House Western ........... 188

Wren, Long-billed Marsh .......... 190

Wren, Rock ................ 185

Wren, Short-billed Marsh ......... 190

Wren, Winter ............... 189

Yellow-throat, Florida ......... 173

Yellow-throat, Maryland ........... 173

Yellow-throat, Northern .......... 173

Yellow-throat, Western .......... 173 
…… 


\section{FLOWER GUIDE}

By CHESTER A. REED, B. S.

A GUIDE to the common wild flowers found in the Eastern and Middle States. Wild Flower Guide is the same size and scope as Bird Guide. It has had an extraordinary sale and has been adopted and used in quantities in many of our leading colleges and schools.

The COLORED ILLUSTRATIONS, 192 in number, are beautiful, artistic and accurate reproductions from oil paintings; the finest series ever made. The text tells where each is found, when it blooms, whether in woods, fields, swamps, etc., the height that the plant attains, whether it is self-fertilized or cross fertilized by insects and how ; in fact it gives a great deal more information than one would think possible in a book to fit comfortably in the pocket.

Bound in Flexible Linen, net, $\$ 1.00$; in Leather, net, $\$ 1.25$; postage, $5 c$.

\section{NATURE STUDIES-IN FIELD AND WOOD}

By CHESTER A. REED, B. S.

THIS book is destined to be one of the most important that the author has written. Absorbingly interesting in itself, yet its greatest value will lie in the fact that it will lead the reader to realize how blind he has been to the many wonderful things that are happening on every hand.

Ix pages; size- $5^{1 / 2} \times 7^{1 / 2}$ in. 40 illustrations in color, and black and white. 60 c. net; postage $10 c$. 


\section{WATER BIRDS}

\section{By CHESTER A. REED, B.S.}

7 HIS book is uniform in size and scope with LAND BIRDS. It includes all of the Water Birds, Game Birds and Birds of Prey, east of the Rockies. Each species is ILLUSTRATED IN COLOR from oil paintings; the bird, its habits and nesting habits are described.

The pictures show more than 230 birds in color, every species found in our range. They exceed in number those in any other bird book. In quality they cannot be surpassed-exquisite gems, each with an attractive background, typical of the habitat of the species.

"LAND BIRDS" and "WATER BIRDS" are the only books, regardless of price, that describe and show in color every bird. 250 pages, neatly boxed.

Bound in Flexible Linen, net, $\$ 1.00$; in Leather, net, $\$ 1.25$; postage, 5 c.

\section{NATURE STUDIES-BIRDS}

\section{By CHESTER A. REED, B.S.}

UST the sort of reading that will start the young folks along the right paths in the study of birds. True stories of bird life as narrated in an interesting form by Uncle George to Dorothy and Dick.

Size $-51 / 2 \times 71 / 2$ in.; 112 pages. Illustrations-Forty in color.

Neatly bound in Gray Cloth, 60c. net; postage 10c. 


\section{WESTERN BIRD GUIDE}

\section{BIRDS OF THE ROCKIES AND WEST TO THE PACIFIC}

1 COMPANION volume to the Eastern Pocket Guides. With notes on all the land and A water birds in the Rockies and West to the Pacific Coast, and a colored illustration of each bird. It completes the Pocket Bird Guide Series for the United States. 255 pages, neatly boxed.

Bound in Flexible Linen, net, $\$ 1.00$; in Leather, net, $\$ 1.25$; postage, $5 \mathrm{c}$.

\section{ILLUSTRATED BIRD DICTIONARIES}

CIVING a description and an accurate pen and ink illustration of every bird found J East of the Rocky Mountains. With a space after each bird for the student to make his own marginal notes.

"Land Birds of Eastern North America" "Water Birds, Game Birds, and Birds of Prey." Each Volume bound in strong, paper covers, 35 cents postpaid. GUIDE TO TAXIDER MY

$\triangle$ PRACTICAL and thorough instructor in the art of mounting birds, mammals, A head, fish, etc. We have an illustrated prospectus for those interested. Fully illustrated; cloth bound; 3 IO pages. $\$ 1.65$ postpaid. 


\section{CAMERA STUDIES OF WILD BIRDS IN THEIR HOMES}

\section{By CHESTER A. REED, B.S.}

" CAMERA STUDIES" has 250 photographs of events right in birds' homes. These pictures are selected from the author's collection of over 2000 bird photographs, this being one of the best collections of pictures of free, living

wild birds in existence.

Many rare and interesting poses are faithfully shown by the camera. For instance, a pair of adult Chipping Sparrows, standing on a branch by the sides of their four young, are engaged in pulling apart a large worm that was too large to be given whole.

The stories accompanying these pictures are as interesting as the photographs and above all they are all actual facts.

300 pages, $5^{1 / 2} \times 7^{1} / 2$ in.; 250 photographs of living, wild birds.

Handsomely bound in Cloth, $\$ 2.00$ net; postage $20 \mathrm{c}$.

\section{WILD FLOWERS}

By CHESTER A. REED, B.S.

A LARGER and more complete work than Flower Guide, with full-page plater A showing 320 Wild Flowers in NATURAL COLORS. An original, beautiful. complete, interesting and accurate work on this most interesting of subjects. 450 pages. Handsomely bound in cloth. $\$ 2.50$ net; postage $15 \mathrm{c}$. 


\section{NORTH AMERICAN BIRDS' EGGS}

By CHESTER A. REED, B.S.

TCHIS is the only book on the market that gives illustrations of the eggs of 1 all North American birds. Each egg is shown FULL SIZE, photographed directly from an authentic and well marked specimen. There are a great many full-page plates of nests and eggs in their natural situations.

The habitat and habits of each bird are given.

It is finely printed on the best of paper and handsomely bound in cloth. 350 pages $-6 \times 9$ inches. $\$ 2.50$ net; postage $25 \mathrm{c}$.

\section{GUIDE TO THE MUSHROOMS}

BY EMMA TAYLOR COLE

TELLS HOW, WHEN and WHERE they grow; how to collect and prepare them for the table; describes the common kinds, both edible and poisonous. Handsomely illustrated with about 70 halftones from photographs of living mushrooms and five PLATES IN COLOR. Uniform with "Wild Flowers."

$\$ 1.50$ net; postage $10 \mathrm{c}$.

\section{GOLDFISH, AQUARIA AND FERNERIES}

TOW to make aquaria. How to fit them up; all about goldfish and fresh water fish that are suitable for the aquarium. Water plants are described, as well as many curiosities that can be kept in the tanks. All these things are FINELY ILLUSTRATED. Cloth bound, $50 \mathrm{c}$ : postage $5 \mathrm{c}$. 


\title{
BIRDS OF EASTERN NORTH AMERICA
}

\author{
By CHESTER A. REED, B.S.
}

$\mathrm{T}$

HIS will undoubtedly be THE BIRD BOOK of the year. It is authentic. The author KNOWS birds. He has studied them for thirty years-in the hand, for plumage, and in their haunts, for habits. He has studied them in their homes and has photographed hundreds as they were actually feeding their young. Besides being able to write about these things in an interesting and instructive manner, he is classed as one of the foremost bird artists in America. This rare combination of Artist-Author-Naturalist has produced, in "Birds of Eastern North America," the ultimate bird book.

The descriptive text gives the important and characteristic features in the lives of the various species.

The illustrations-well, there are 408 PICTURES IN NATURAL COLORS; they show practically every species including male, female and young when the plumages differ, and they are perfectly made by the best process. No other one bird book ever had anywhere near as many accurately colored pictures.

Bound in cloth, handsomely illuminated in gold; 464 pages $\left(4^{1 / 2} \times 6 \mathrm{~T} / 2\right) ; 408$ colored illustrations; every bird described and pictured.

\section{$\$ 3.00$ net; postage $15 c$.}




\title{
AMERICAN GAME BIRDS
}

\author{
By CHESTER A REED, B. S.
}

CERTAIN species and families of our wild birds are classed as game and can, at certain seasons, be legally hunted for sport or for food. A great number of books have been written for sportsmen and by sportsmen, most of them containing but a very few black and white illustrations of some of the species mentioned. As far as we know, AMERICAN GAME BIRDS is the only sportsman'r book illustrating nearly all of these birds in NATURAL COLORS. With it, the novice can identify any game bird he secures or sees, and the old-timer, as well, can see just what sportsmen in other sections of the country are shooting. Thr illustrations are excellent reproductions by the very best process from water-colo1 paintings made directly from the birds.

The text portrays their habits just as truly as the pictures do their appearance, and the two together give the reader a correct impression of each species, such a: can be gained in no other way except by long association with the birds. Mr. Reed knows birds as few others do, and has hunted, studied and photographed them from Labrador to Florida, and from the Atlantic to the Pacific.

More than roo species illustrated in natural color3.

In handsome Paper Covers, 60c. net; postage, 5c. 


\section{THE BIRD BOOK}

By CHESTER A. REED, B. S.

N R. REED'S new bird book is the most complete guide he has yet made. Unlike the 1 pocket guides which though ideal for field work, cannot because of their size give all the details the student wishes, this book is a whole reference library about birds and their haunts. It contains illustrations in colors of more than seven hundred birds of all varieties from all parts of the country which show the birds more than an inch in height so that every detail of real life is faithfully reproduced. In addition to these illustrations in color there are many hundreds more showing the eggs in life size, and numerous unusual photographs of birds in flight and in their natural haunts

More than 700 Illustrations in colors, and many unusual Bird Photographs. Net, $\$ 3.00$ 


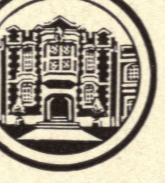

THE COUNTRY LIFE PRESS GARDEN CITY, N. Y. 



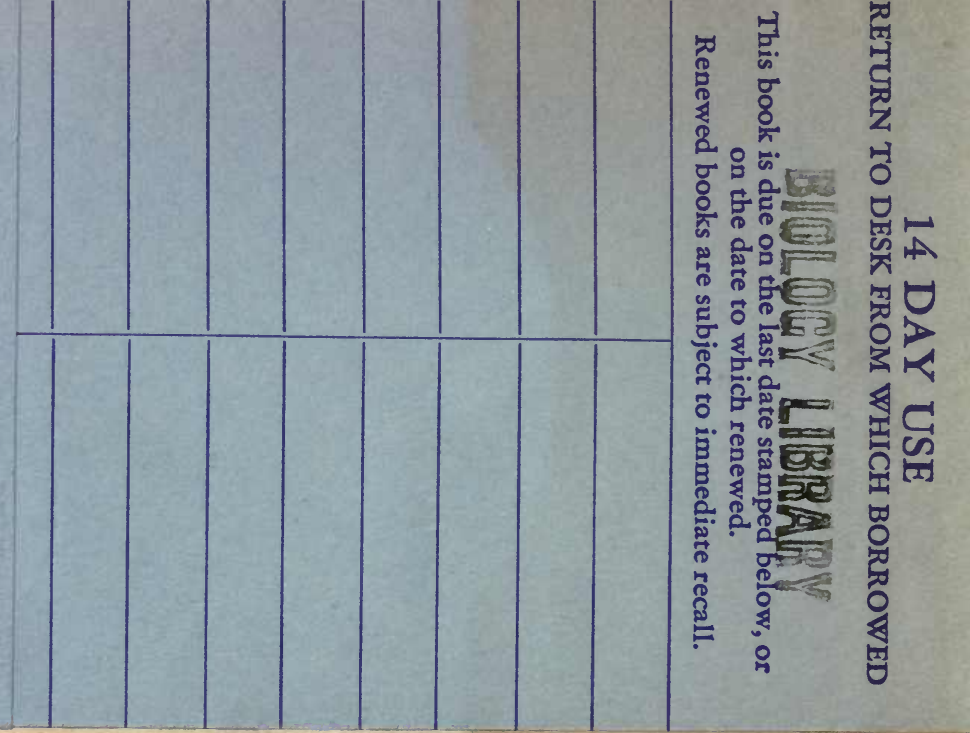



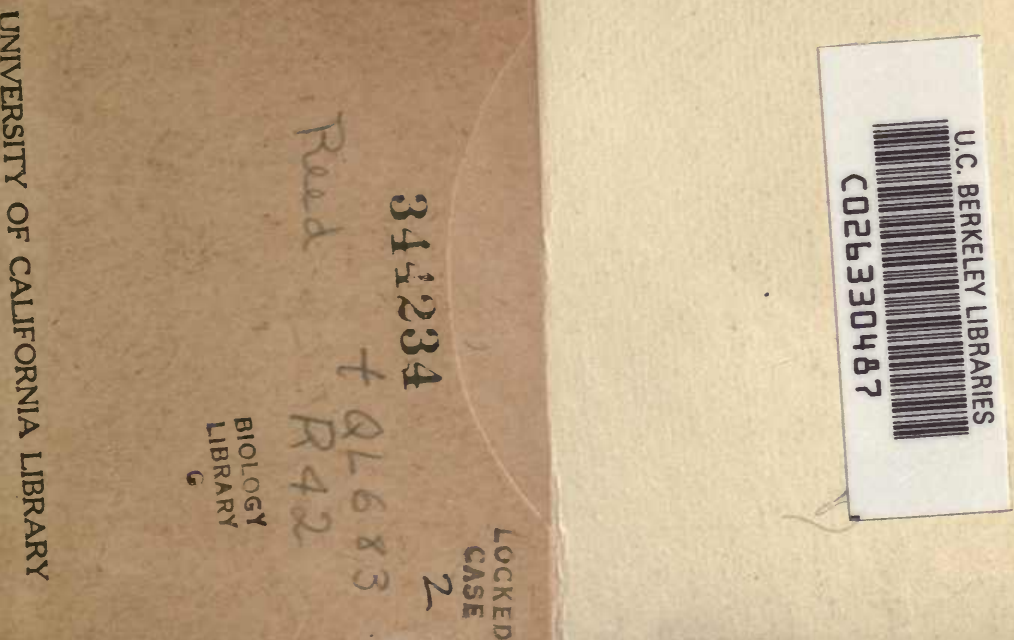
